\title{
2. SAVIVALDYBIŲ VIEŠŲJŲ BIBLIOTEKŲ SISTEMOS VEIKLOS TYRIMAS TAIKANT BIX (BIBLIOTHEKSINDEX) METODIKĄ
}

\author{
Dalia JASKONIENĖ
}

\section{Santrauka}

2013 metais Lietuvos nacionalinès Martyno Mažvydo bibliotekos Bibliotekininkystes centras (dabar - Informacijos moksly departamento Bibliotekininkystès skyrius) kartu su Lietuvos apskričiu viešosiomis bibliotekomis (AVB) suorganizavo ir atliko tyrima „BIX (Bibliotheksindex) metodikos taikymas vertinant Lietuvos viešuju biblioteku veikla“. Šis tyrimas apeme aktualy vertinima, kuri atliekant buvo taikoma Europos Sajungoje plačiai žinoma BIX metodika. Tyrimo objektu buvo pasirinktos 58 savivaldybiu pagrindinès viešosios bibliotekos (CB). Šio tyrimo rezultatai parodè, kad kur kas efektyviau bütu vertinti ne tik pagrindines tinklo bibliotekas, bet ir visq savivaldybès viešuju biblioteku sistema [pagrindine biblioteka (CB) + padaliniai (tinklo bibliotekos)]. Tikslesni ir objektyvesni vertinima padetu užtikrinti visos biblioteku sistemos rodikliu skaičiavimas, todel 2014 metais buvo vykdomas II tyrimo etapas "Savivaldybiu viešuju biblioteku sistemos veiklos tyrimas taikant BIX (Bibliotheksindex) metodika".

Tyrimo tikslas - taikant BIX metodika, ivvertinti savivaldybiu viešuju biblioteku sistemu (toliau - SVBS) veikla ir jas reitinguoti.

Tyrimo objektas - 60 SVB sistemu (1281 bibliotekos) veikla. 
Tyrimo uždaviniai: 1) vertinant apskričiu teritorijose veikiančiu SVB veikla, nustatyti ju vieta kiekvienoje iš 4 dimensijų: ištekliu ir infrastruktūros; naudojimosi biblioteka; našumo; plettros; 2) nustatyti rodikliu tinkamuma SVB veiklai vertinti ir joms reitinguoti: pateikti rodikliu aprašymus ir taikymo interpretacijas, apibüdinti bibliotekos vidaus ir išorès veiksnius, darancius i̇taka pagal BIX metodika nustatomiems veiklos rezultatams; 3) pagal BIX metodika ivertinti ir reitinguoti Lietuvos savivaldybiu viešuju biblioteku sistemas, palyginti 2013 ir 2014 metu tyrimais gautus rezultatus.

BIX metodikos pritaikymo rezultatas - viešuju biblioteku reitingavimo sistema: BIX metodikos rezultatai parodo kiekvienos SVB vieta lyginant ja su kitomis bibliotekomis kiekvienoje is 4 dimensiju (18 rodikliu); pagal atitinkama metodika papildomai nustatoma bendroji kiekvienos SVB vieta vertinimo skaleje. SVB duomenys vertinami ir gauti rezultatai grupuojami pagal konkrečios bibliotekos aptarnaujamos bendruomenés dydį.

Šio tyrimo laikotarpis - 2013 metai. Tu metu statistikos duomenys rodikliu vertems skaičiuoti buvo imami is SVB statistinin ataskaitu, paskelbtu statistikos modulyje („Lietuvos biblioteku statistika“, 2014). Gyventoju skaičius 2013 m. pabaigoje (arba 2014 m. pradžioje) nurodomas is Lietuvos statistikos departamento duomenu baziu (Lietuvos statistikos departamentas, 2014).

Tyrimo metu buvo ịvertinta Lietuvos apskričiu teritorijose veikiančiu SVB veikla ir nustatyta ju vieta kiekvienoje iš 4 minetu dimensiju; pateikti rodikliu taikymo išaiškinimai, apibüdinti bibliotekos vidaus ir išorés veiksniai, lemiantys pagal BIX metodika nustatomus veiklos rezultatus. Pagal atitinkama metodika buvo nustatyta kiekvienos bibliotekos bendroji vieta vertinimo skaleje, palyginti $2013 \mathrm{~m}$. ir $2014 \mathrm{~m}$. tyrimu rezultatai.

Apibendrinti šio tyrimo rezultatai ir ju palyginimas su $2013 \mathrm{~m}$. atlikto tyrimo duomenimis rodo, kad aukšciausius vertinimus gavo tos SVB, kuriu pagrindines bibliotekos taip pat buvo ìvertintos geriausiai, o žemiausi vertinimai atiteko toms SVB, kuriu pagrindinès bibliotekos negavo aukštu 
ivertinimu. Panašios arba sutampančios tu pačiu savivaldybių pagrindiniu ir viso tinklo biblioteku pozicijos reitinge, vertinant dveju iš eilès metu rodiklius, atskleidžia tam tikras viešuju biblioteku büklès ir raidos tendencijas kiekvienoje savivaldybëje ir leidžia daryti prielaida, kad teigiamiems pokyčiams reikalingos ilgalaikès suvienytos biblioteku ir ju savininku pastangos. Ypač tai taikytina I dimensijos - išstekliai ir infrastruktūra - rodikliams, apibüdinantiems bibliotekos išteklius, kuriu bent kiek žymesni pokyti galima užtikrinti per ilgesni nei vienerių metų laikotarpi.

SVB tinklo biblioteku vertinimas ir ju rodikliu palyginimas yra svarbi ir vertinga biblioteku atstovavimo priemone savininko funkcijas vykdančiose institucijose.

\subsection{Tyrimo metodologija ir metodika}

\subsubsection{Tyrimo metodologija}

Informacinëje visuomenëje bibliotekos, taikydamosi prie vartotoju, jų poreikių, nuolat keičiasi. Dẻl nuolatinių vis intensyvëjančių aplinkos pokyčiu svarbesnis tampa biblioteku valdymas ir su juo susiję iššǔkiai. Viena iš valdymo sričių - veiklos vertinimas.

Lietuvos Respublikos terminų banke nurodyta, kad veiklos vertinimas yra „analizuojama veiksmu programos (ar jos dalies) igyvendinimo eiga, siekiant papildyti veiksmu programos stebèseną ir tobulinti veiksmų programos igyvendinimą" [14]. Bibliotekose vykdomas veiklos vertinimas yra vienas iš svarbiausių būdų parodyti, kad biblioteka yra naudinga ir svarbi tam tikroms visuomenès grupèms. Biblioteku veiklos vertinimas reikalingas dèl įvairių priežasčių: dèl nuolat didejjančių reikalavimų biblioteku teikiamoms paslaugoms; dèl būtinybès pagrissti priimamus sprendimus; bibliotekų veiklos išlaidas; dèl poreikio įvertinti veiklos kokybę.

Biblioteka dažniausiai traktuojama kaip paslaugas teikianti institucija, jos veiklos esmę sudaro paslaugų kūrimas ir teikimas vartotojams. 
Todèl paslaugos, svarbiausiu jos aspektų supratimas, paslaugu ypatybių žinojimas ir panašǔs klausimai pagrindžia bibliotekos veiklos vertinimo strategijas ir taktikas.

Bibliotekos veikla susideda iš atskirų dalių, kurių vartotojai dažniausiai nemato ir net nenumano jų esant: kitaip tariant, didžioji bibliotekos veiklos dalis tik netiesiogiai prisideda prie bibliotekos veiklos rezultato - paslaugu - kūrimo. Šiandien nebepakanka laikytis požiūrio ị biblioteką kaip ị savaime svarbią ir gerai dirbančią instituciją, privalomai išlaikomą iš valstybès ir savivaldybių biudžeto. Biblioteka veikia konkurencinèje aplinkoje, kuri, intensyviai plečiantis produktų ir paslaugu ịvairovei bei jų skaičiui, neaplenkia ir visuomeninio sektoriaus. Konkurencija gamybos šakose niekam nekelia abejonių, tačiau tiek gamybinès, tiek negamybinès organizacijos esmè nesiskiria - abi siekia sukurti produktą ar paslaugą ir pateikti vartotojui. Kiekvienam visuomenès nariui daugiau ar mažiau yra žinomi biblioteku "produktai“ - teikiamos informacinès paslaugos.

Kol kas sunku pateikti vienintelę paslaugos apibrèžtị, nes daugumai veiklos rūšiu, pripažįstamų paslaugomis, būdingos savybès ịvardijamos ne viename apibrèžime. Vis dèlto galima nurodyti keletą paslaugu bruožų, kurios minimos daugelyje apibrěžčiu, tai:

- neapčiuopiamumas (nematerialumas);

- nekaupiamumas;

- neatskiriamumas (paslaugos teikimo ir vartojimo vienové arba vienalaikiškumas);

- heterogeniškumas (nevienalytiškumas);

- vartotojo dalyvavimas paslaugos teikimo procese;

- nuosavybiškumo nekeičiamumas.

Žinoti bibliotekų paslaugu ypatybes yra svarbu, nes jos nulemia bibliotekos veiklos vertinimą; būtent šiu bibliotekos informacijos paslaugu sukeliami sunkumai ir trukdo sèkmingai kurti bei igyvendinti veiklos vertinimo kultūrą $[19$, p. 18]. 
Tarptautiniu lygmeniu veiklos vertinimo problema biblioteku ir informacijos paslaugų srityje keliama ir analizuojama jau seniai. Mejginimų vertinti bibliotekų veiklą pasaulyje yra nemažai. $2013 \mathrm{~m}$. Billo ir Melindos Gatesų fondas (Bill \& Melinda Gates foundation) mokslinių tyrimų bendrovei TNS užsakè atlikti tyrimą 17 Europos Sąjungos šalių, siekiant nustatyti, kaip yra suvokiamos bibliotekos ir koki poveiki jos daro vartotoju gyvenimui [3].

Aktualus viešųjų bibliotekų tyrimas buvo atliktas Latvijoje. Jo tikslas buvo apskaičiuoti ir išanalizuoti Latvijos viešųjų bibliotekų daromą ekonomini poveikị ir sukurtą naudą per tam tikrą laikotarpi (šis tyrimas apima 2008-2010 metus), taip pat nefinansinę viešųjų bibliotekų sistemos kuriamą bei teikiamą naudą visuomenei [5]. 2012-2014 m. Lietuvoje buvo vykdomas projektas LiBiTOP (Lietuvos bibliotekų tinklo optimizavimo galimybiu studija), kurio metu buvo atliekamas Lietuvos valstybinès reikšmès ir apskričių viešųjų bibliotekų strategijų, kokybinių ir kiekybinių veiklos rodiklių tyrimas (2013). Jis gali būti laikomas išsamiausia Lietuvoje atlikta biblioteku veiklos vertinimo analize [15].

Vienas iš bibliotekų veiklos vertinimo metodų yra subalansuotu rodikliu sistema. Šią sistemą, siekdami gauti visapusišką (subalansuota) organizacijos veiklos vaizdą, sukūre Robertas S. Kaplanas ir Davidas P. Nortonas, finansinius organizacijos veiklos rodiklius papildydami nefinansiniais [11]. Subalansuotų rodiklių sistema vertinant bibliotekų veiklą plačiai naudojama. Pavyzdžiui, ja grindžiamas Vokietijos viešujų ir akademinių bibliotekų veiklos vertinimo projektas BIX, Nyderlandų biblioteku veiklos lyginamosios analizės projektas.

Subalansuotų rodiklių sistema yra grindžiami ir bibliotekų veiklos vertinimo standartai. Pastaruoju metu bibliotekų veiklos statistikos standartų leidyboje ịvykę reikšmingi pokyčiai sukūrè pagrindą vertinti ne tik bibliotekų teikiamas tradicines, bet ir elektronines paslaugas. Tarptautiniuose standartuose ISO 2789:2013 Informacija ir dokumentavimas. Tarptautine biblioteku statistika ir ISO 11620:2014 Informacija ir doku- 
mentavimas. Bibliotekos veiklos rodikliai standartizuojamas elektroniniu informacijos paslaugu bibliotekose vertinimas. Šie standartai yra universalūs, skirti visų tipų bibliotekoms [7;8].

Vokietijos viešųuı ir akademinių bibliotekų veiklos vertinimo projekto BIX programoje rodiklių apibrèžtys daugeliu atvejų sutampa su tarptautiniame tarptautinès bibliotekų statistikos standarte (ISO 2789:2013) pateiktais rodiklių apibrèžimais, o, aprašant rodiklių panaudojimo metodus, iš dalies remiamasi jau minètu tarptautiniu ISO 11620:2014 standartu. Rodikliai yra pristatomi ir atitinka subalansuotų rodiklių sistemą, o sistemos viduje jie pateikti pagal aptarnavimo sritis. Subalansuotu rodikliu sistemos struktūros naudojimas padeda atsižvelgti $\mathfrak{i}$ atitinkamus valdymo klausimus ir nustatyti „pusiausvyrą" tarp vartotojų interesų ir ekonominio efektyvumo, institucijos efektyvumo ir galimybès įveikti ateities iššǔkius [16].

2013 m. tuometis Lietuvos nacionalinès Martyno Mažvydo bibliotekos Bibliotekininkystès centras ir apskričių viešosios bibliotekos vykdè tyrimą „BIX (Bibliotheksindex) metodikos taikymas vertinant Lietuvos viešųjų bibliotekų veiklą". Vienas šio tyrimo uždavinių buvo nustatyti, ar ši metodika tinka Lietuvos savivaldybių viešosioms bibliotekoms vertinti ir reitinguoti. Tyrimo metu buvo vertinamos ir reitinguojamos savivaldybiu pagrindinès viešosios bibliotekos. Tyrimo rezultatai parodè, kad, vertinant ir reitinguojant nedidelị biblioteku skaičių (58), konkrečios bibliotekos vietą reitinge nuo aukščiausios iki žemiausios pozicijos nulèmè minimalūs rodiklių verčių skirtumai, nors objektyviai esminių skirtumų tų biblioteku veikloje nèra arba tie skirtumai per maži, kad atskleistų jų veiklos privalumus ir trūkumus. Visų šalies viešujų bibliotekų sistemų reitingavimas suteikia galimybę kur kas objektyviau ịvertinti kiekvienos bibliotekos rezultatus. Didesnį vertinimų objektyvumą padeda užtikrinti visos biblioteku sistemos rodiklių skaičiavimas, neapsiribojant vien pagrindinès bibliotekos rodikliais. 
$2014 \mathrm{~m}$. buvo vykdomas II šio tyrimo etapas „Savivaldybių viešųjų biblioteku sistemos veiklos tyrimas taikant BIX (Bibliotheksindex) metodiką".

Tyrimo tikslas - įvertinti ir reitinguoti savivaldybių viešųjų bibliotekų sistemu (toliau - SVB) veiklą taikant BIX metodiką.

Tyrimo objektas - 60 SVB (1281 bibliotekos) sistemų veikla.

Tyrimo uždaviniai: 1) vertinant apskričių teritorijose veikiančių SVB veiklą, nustatyti jų vietą kiekvienoje iš 4 dimensijų: išteklių ir infrastruktūros; naudojimosi biblioteka; našumo; plètros; 2) pateikti rodiklių taikymo interpretacijas, apibūdinti bibliotekos vidaus ir išorès veiksnius, darančius įtaką pagal BIX metodiką nustatomiems veiklos rezultatams; 3) pagal BIX metodiką įvertinti ir reitinguoti Lietuvos savivaldybių viešųjų bibliotekų sistemas, palyginti 2013 ir 2014 metų tyrimais gautus rezultatus.

Siekiant apibendrinti bibliotekų veiklos duomenis ir daryti pagrịstas išvadas apie jų veiklos rezultatus, tarp jų ir trūkumus, tyrime buvo taikomas lyginamasis metodas (lyginamoji analizè). Taikant ši metoda, vienos bibliotekos ar biblioteku grupes veiklos sąnaudos ir rezultatai yra lyginami su kitos bibliotekos ar kitų biblioteku grupių rezultatais, taip gaunama naudingos informacijos apie lyginamų bibliotekų ar jų grupių veiklą. Savivaldybių viešųjų bibliotekų palyginimas naudingas todèl, kad šios bibliotekos atlieka tą patị vaidmenị skirtingose teritorijose, jų vartotojų skaičius ir sudètis - panašǔs.

Tyrimui pasitelkti 4 dimensijų rodikliai (18 rodiklių).

Rodiklių duomenims surinkti ir interpretuoti buvo remiamasi kokybinès ir kiekybinès turinio analizės, aprašomosios statistikos metodais. Surinkti duomenys buvo grupuojami pagal konkrečios bibliotekos aptarnaujamos bendruomenès dydị. Suskirsčius bibliotekas ì grupes, visi tolesni skaičiavimai buvo atliekami atskirai kiekvienoje grupëje. Nustatant kiekvienos bibliotekos poziciją kitų tos grupès bibliotekų atžvilgiu, buvo apskaičiuojamas kiekvieno rodiklio procentilis. Pagal gautus rezultatus nustatomas bibliotekos reitingas. Bibliotekų reitingavimas pagal BIX 
metodiką yra konkurencingas: jis grindžiamas akivaizdžiais duomenimis ir kokybės valdymu; BIX metodikos duomenu kokybès kontrolè atliekama naudojant detalizuotą 3 etapų procedūrą.

Tolesniuose poskyriuose išsamiau aptariama skaičiavimo metodika ir kokybès valdymas pagal BIX.

Tyrimo metu gauti rezultatai buvo pristatyti bibliotekų specialistų mokymuose, kuriuose dalyvavo Vilniaus, Klaipėdos, Šiaulių ir Panevėžio apskričių ir joms priskirtų teritoriju savivaldybių viešųų bibliotekų darbuotojai, taip pat publikuojant straipsnius profesineje spaudoje ${ }^{1}$.

\subsubsection{BIX (Bibliotheksindex) skaičiavimo metodikos apžvalga}

2013 m. tuometis Bibliotekininkystès centras parengė metodiką, pagal kurią buvo skaičiuojami savivaldybių pagrindinių bibliotekų rodikliai ir ju procentiliai, jų veikla vertinama ir reitinguojama pagal BIX metodiką (I tyrimo etapas). Pirmojo tyrimo etapo rezultatai parodé, kad, vykdant II tyrimo etapą, t. y. vertinant bei reitinguojant savivaldybių viešujų bibliotekų sistemas (SVBS), būtina parengti išsamesnes rekomendacijas, kuriose būtų tiksliai apibrèžtos I tyrimo etape įvairiai interpretuotos sąvokos ir numatyti trūkstamų statistinių duomenų rinkimo bei pateikimo būdai. 2014 m. BIX metodika dar kartą buvo papildyta ir patikslinta. Taikant šią metodiką, bibliotekoms vertinti yra naudojama 18 standartizuotų rodiklių, kurie suskirstyti ị 4 pagrindines duomenų grupes (dimensijas) (žr. 1 pav.).

JASKONIENĖ, Dalia. Savivaldybių viešujų bibliotekų reitingas. Tarp knygu, 2015, Nr. 7-8 (678-679), p. 2-6.; Nr. 9 (680), p. 6-11. 

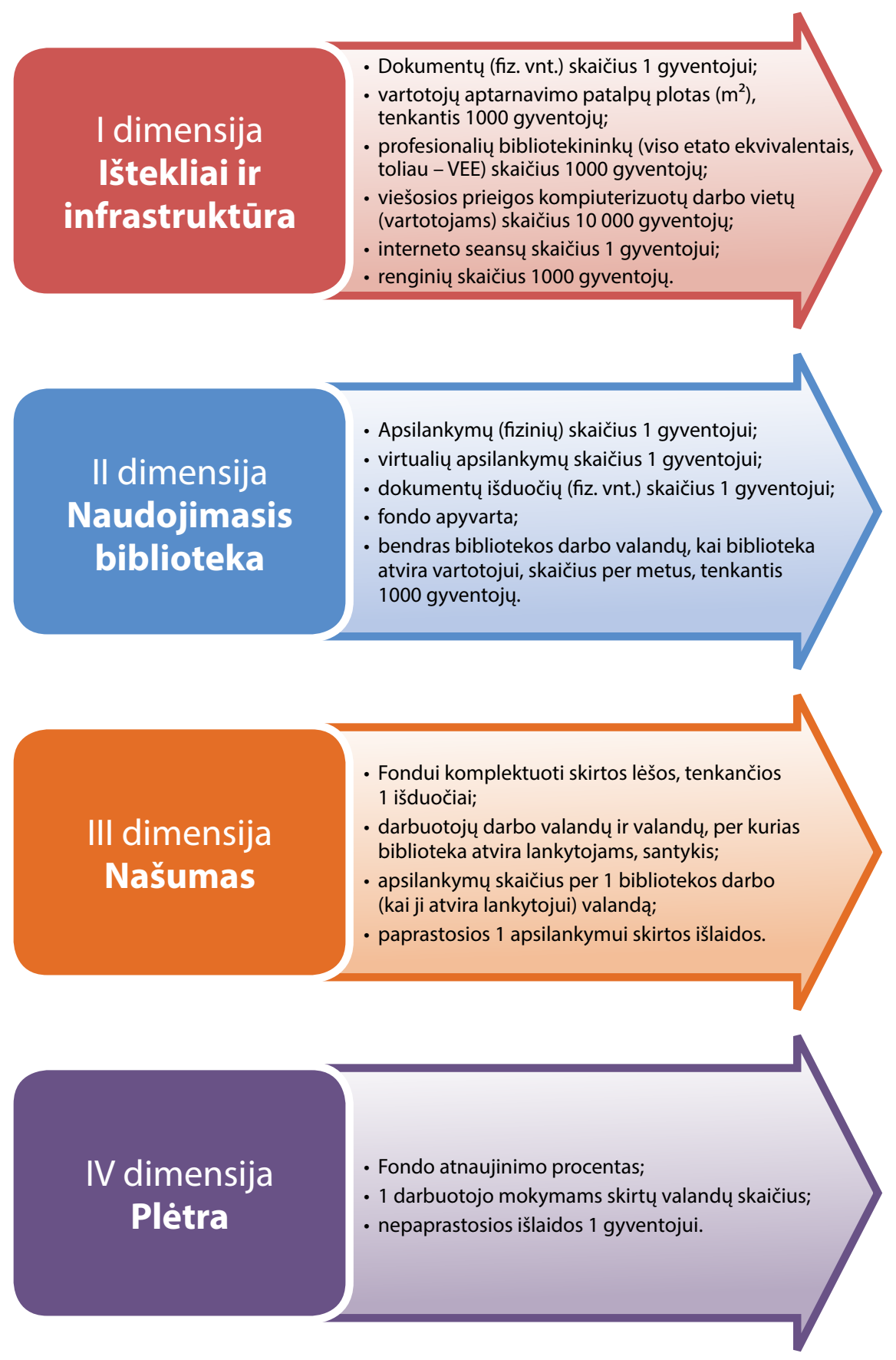

1 pav. BIX I-IV dimensiju rodikliai [1] 
Beveik visi šie rodikliai yra žinomi ir taikomi Lietuvos viešosiose bibliotekose; jiems apskaičiuoti pakanka LNB Lietuvos integralios bibliotekų informacinès sistemos (toliau - LIBIS) bibliotekų statistikos duomenu bazei pateiktų viešųu bibliotekų statistinių duomenų. BIX metodikoje yra tik trys iki šiol analizuojant Lietuvos viešųjų bibliotekų veiklą nenaudoti rodikliai:

- bendras bibliotekos darbo valandu, kai ji atvira vartotojams, skaičius per metus, tenkantis 1000 gyventoju (II dimensija, 5 rodiklis);

- lankytojus aptarnaujančių darbuotojų darbo valandų ir valandų, per kurias biblioteka atvira lankytojams, santykis (III dimensija, 2 rodiklis);

- 1 darbuotojo mokymams skirtų valandų skaičius (IV dimensija, 2 rodiklis).

Toliau pateikiamas kiekvieno 1 paveiksle nurodyto rodiklio išsamus aprašymas.

\section{I dimensija. Ištekliai ir infrastruktūra}

\section{Dokumentų (fiz. vnt.) skaičius 1 gyventojui}

Apibrèžtis ir paskirtis. Dokumentų fondo (fiz. vnt.) ir aptarnaujamų gyventojų skaičiaus santykis. Šis rodiklis įvertina apsirūpinimą dokumentais, t. y. vidutinị dokumentų skaičių, tenkantị 1 aptarnaujamos bendruomenès gyventojui.

Rodiklio taikymo pagrindimas. Gyventojų aprūpinimas dokumentais yra labai svarbus viešosios bibliotekos veiklos aspektas. Rodiklis leidžia nustatyti, kaip bibliotekos dokumentais aprūpina aptarnaujamą bendruomenę. Dokumentų skaičius 1 gyventojui leidžia įvertinti fondo dydžio pakankamumą, bet neanalizuoja fondo ir jo atitikties realiems vartotojų poreikiams.

Rodiklio skaičiavimo būdas. $\mathrm{R} 1$ = A / B, kur A - SVB fondo dokumentų (fiz. vnt.) skaičius per metus, B - aptarnaujamų gyventojų skaičius. 
Duomenų šaltiniai. „LIBIS bibliotekų statistikos modulis“ (2013) ir Lietuvos statistikos departamento duomenys $(2014)^{2}$.

Rodiklio šaltinis. Rodiklis pritaikytas iš LST ISO 11620:2014 ir Library index BIX $(2014)^{3}$.

\section{Vartotojų aptarnavimo patalpų plotas $\left(\mathrm{m}^{2}\right)$, tenkantis 1000 gyventojų}

Apibrèžtis ir paskirtis. Vartotojų aptarnavimo patalpų naudingasis plotas $\left(\mathrm{m}^{2}\right) 1000$ gyventoju. Šiuo rodikliu vertinama bibliotekos, kaip studijų ir susitikimų vietos bei mokymosi centro, svarba. Jis parodo savininko (institucijos) indèli šiems tikslams igyvendinti.

Rodiklio taikymo pagrindimas. Bibliotekos patalpų plotas yra vienas svarbiausių veiksnių, užtikrinančių bibliotekos galimybes teikti paslaugas bendruomenei ir lemiančių šių paslaugu pobūdị, apimtis ir kokybę. Nuo patalpų ploto priklauso, kaip išdèstomas dokumentų fondas, ar jis lengvai prieinamas vartotojams, ar patogu jame atlikti paiešką, kiek galima įrengti darbo vietų vartotojams, ar įmanoma atskirti ir izoliuoti tyliąsias zonas, užtikrinant vartotojams patogų darbą bibliotekoje, ar yra galimybè ịrengti atskiras erdves renginiams.

Rodiklio skaičiavimo būdas. $\mathrm{R} 2=\mathrm{A} / \mathrm{B}$ x 1000, kur A - SVB patalpu plotas $\left(\mathrm{m}^{2}\right)$, kuriose per metus yra teikiamos paslaugos vartotojams; B - aptarnaujamų gyventojų skaičius.

\section{Profesionalių bibliotekininkų (viso etato ekvivalentais, toliau - VEE) skaičius 1000 gyventoju}

Apibrèžtis ir paskirtis. Profesionalių darbuotojų (VEE) ir aptarnaujamų gyventojų skaičiaus santykis. Rodiklio paskirtis - nustatyti profesionalių bibliotekininkų skaičių, tenkantị 1000 gyventojų. Profesionalių bibliotekininkų skaičius vertinamas kartu su kitais rodikliais, matuojančiais paslaugų kokybę ir procesų efektyvumą.

Čia ir toliau tekste, pateikiant išsamų rodiklių aprašymą, nurodyti tie patys duomenų šaltiniai. Čia ir toliau tekste, pateikiant išsamų rodiklių aprašymą, nurodyti tie patys duomenų šaltiniai. 
Rodiklio taikymo pagrindimas. Profesionalių bibliotekininkų skaičius tiesiogiai užtikrina ne tik pagrindinių viešosios bibliotekos funkcijų vykdymą, bet ir jos teikiamų paslaugų pasiūlą bei kokybę: kuo didesnis bibliotekininkų skaičius, tuo didesnès bibliotekos galimybès kurti naujas paslaugas ir teikti jas už bibliotekos ribų, gerinti šių paslaugų prieinamumą atsižvelgiant ì gyventoju poreikius, didinti elektroninių paslaugų pasiūlą, diferencijuoti bibliotekininkų pareigines funkcijas ir užtikrinti aukštesnị jų kompetencijos lygị konkrečioje veiklos srityje, sudaryti sąlygas darbuotojams kelti profesinę kvalifikaciją dalyvaujant mokymuose. Būtiną personalo etatų skaičių taip pat lemia bibliotekos pastatų skaičius, patalpu dydis, planavimas, savitarnos įrenginių naudojimas ir kiti veiksniai.

Rodiklio skaičiavimo būdas. $\mathrm{R} 3=\mathrm{A} / \mathrm{B}$ x 1000, kur A - SVB profesionalių bibliotekininkų (VEE) skaičius per metus; B - aptarnaujamų gyventojų skaičius.

\section{Viešosios prieigos kompiuterizuotų darbo vietų (vartotojams) skaičius 10000 gyventojų}

Apibrèžtis ir paskirtis. Bibliotekos viešosios prieigos kompiuterizuotų darbo vietų ir aptarnaujamų gyventojų skaičiaus santykis. Rodiklis leidžia nustatyti viešosios prieigos kompiuterizuotų darbo vietų bibliotekoje skaičių, tenkantị 10000 gyventojų, ir ịvertinti prieigos prie elektroninès informacijos galimybes.

Rodiklio taikymo pagrindimas. Vienas svarbiausių viešosios bibliotekos uždavinių yra teikti bendruomenei informacines paslaugas. Viešosios prieigos kompiuterizuotų darbo vietų skaičius gyventojams yra itin svarbus veiksnys, padedantis užtikrinti prieigą prie elektroninės informacijos ir mažinantis gyventoju skaitmeninę atskirtị. Šis rodiklis susijęs su bibliotekos patalpu plotu, užtikrinančiu galimybę irengti pakankamą kompiuterizuotų darbo vietų skaičiu, nuo kurių priklauso interneto seansų skaičius. 
Rodiklio skaičiavimo būdas. $\mathrm{R} 4$ = A / B x 10 000, kur A - SVB kompiuterizuotų darbo vietų skaičius per metus; $\mathrm{B}$ - aptarnaujamų gyventojų skaičius.

\section{Interneto seansų skaičius 1 gyventojui}

Apibrèžtis ir paskirtis. Interneto seansų ir aptarnaujamų gyventojų skaičiaus santykis. Rodiklis padeda nustatyti, kaip aktyviai aptarnaujami gyventojai naudojasi viešosios interneto prieigos paslauga.

Rodiklio taikymo pagrindimas. Šis rodiklis parodo, kokiu mastu biblioteka savo vartotojams teikia interneto prieigą. Interneto seansu skaičius atspindi bibliotekos turimų išteklių - kompiuterizuotų darbo vietų panaudojimą.

Rodiklio skaičiavimo būdas. $\mathrm{R} 5$ = A / B, kur A - interneto seansų SVB skaičius per metus; B - aptarnaujamų gyventojų skaičius.

\section{Renginių skaičius 1000 gyventojų}

Apibrèžtis ir paskirtis. Rodiklis skirtas ịvertinti, kiek bibliotekos organizuojamų renginių tenka 1000 gyventojų. Rodiklis parodo, kiek svarbus bibliotekai yra kultūrinis vaidmuo bendruomenëje.

Rodiklio taikymo pagrindimas. Viešosios bibliotekos siekia aptarnaujamai bendruomenei užtikrinti galimybę dalyvauti kultūriniame gyvenime. Pati biblioteka siūlo kultūros paslaugas, daugiausia - ịvairaus pobūdžio žodinius ir vaizdinius renginius. Rodiklis padeda nustatyti, kiek biblioteka skiria pastangu šiai veiklai, ar renginiai laikomi svarbia veikla.

Rodiklio skaičiavimo būdas. R6 = A / B x 1000, kur A-SVB renginių skaičius per metus; B - aptarnaujamu gyventojų skaičius. Vadovaujantis ISO 2789:2013, i apskaitą traukiami literatūrinio, kultūrinio ir edukacinio pobūdžio renginiai. Tačiau nę̧traukiami mokomieji renginiai vartotojams (kursai, paskaitos, mokomosios ekskursijos, kaip naudotis bibliotekos paslaugomis), kitų organizacijų bibliotekos patalpose organizuojami renginiai. 


\section{II dimensija. Naudojimasis biblioteka}

\section{Apsilankymų (fizinių) skaičius 1 gyventojui}

Apibrèžtis ir paskirtis. Bendras fizinių apsilankymų bibliotekoje skaičius per metus 1 gyventojui. Šis rodiklis parodo, kiek vidutiniškai apsilankymų tenka aptarnaujamos bendruomenès 1 gyventojui. Rodiklis leidžia tirti naudojimosi biblioteka ypatumus ir nustatyti, kiek bibliotekos, kaip fizinès vietos, teikiamos paslaugos aktualios gyventojams.

Rodiklio taikymo pagrindimas. Rodiklis parodo, ar gyventojai lankosi bibliotekoje ir naudojasi jos ištekliais bei paslaugomis. Apsilankymų (fiziniu) skaičius bibliotekoje priklauso nuo daugelio veiksnių: dokumentu fondo dydžio, jo turinio, fondo atnaujinimo procento, bibliotekos patalpu ploto, kompiuterizuotu darbo vietų skaičiaus vartotojams, renginių skaičiaus, lankytojų aptarnavimo laiko, nustatytų patogiu gyventojams aptarnavimo valandų ir pan. Šis rodiklis priklauso nuo aptarnaujamos teritorijos gyventoju skaičiaus ir registruotų vartotojų skaičiaus.

Rodiklio skaičiavimo būdas. $\mathrm{R} 1$ = A / B, kur A - bendras apsilankymų SVB skaičius per metus; B - aptarnaujamu gyventojų skaičius.

\section{Virtualių apsilankymų skaičius 1 gyventojui}

Apibrěžtis ir paskirtis. Bendras metinis virtualių apsilankymų skaičius, tenkantis 1 gyventojui. Rodiklis padeda nustatyti naudojimosi bibliotekos elektroninèmis paslaugomis intensyvumą.

Rodiklio taikymo pagrindimas. Virtualus apsilankymas yra vartotojo užklausa, pateikiama atsidarius bibliotekos tinklalapi esant už bibliotekos ribų, nepaisant puslapių ar peržiūrètu elementų skaičiaus (ISO 2789:2013). Virtualūs lankytojai - tai lankytojai, kurie pasinaudojo bibliotekos elektroninėmis paslaugomis (pavyzdžiui, internetiniais katalogais, duomenų bazėmis, elektroniniais periodiniais leidiniais, elektronine bibliografine informacija ir t. t.) būdami už bibliotekos ribų. Šis rodiklis 
parodo bibliotekos teikiamų elektroninių paslaugų populiarumą, patrauklumą bei naudojimosi jomis intensyvumą.

Rodiklio skaičiavimo būdas. $\mathrm{R} 2=\mathrm{A} / \mathrm{B}$, kur A - bendras virtualių apsilankymų SVB skaičius per metus; B - aptarnaujamų gyventojų skaičius.

\section{Dokumentų išduočių (fiz. vnt.) skaičius 1 gyventojui}

Apibrèžtis ir paskirtis. Bendras metinis bibliotekos išduočių skaičius 1 gyventojui. Rodikliu siekiama nustatyti aptarnaujamos bendruomenès gyventojų naudojimosi bibliotekos fondu dažnį. Šiuo rodikliu galima naudotis nustatant dokumentų fondo kokybę ir bibliotekos gebèjimus populiarinti fondą.

Rodiklio taikymo pagrindimas. Dokumentų išduotys parodo bibliotekos dokumentų fondo naudojimo intensyvumą; tai nemažai priklauso nuo jo turinio atitikties aptarnaujamos bendruomenès poreikiams. Rodiklis yra susijęs su fondo dydžiu ir fondo turiniu, fondo atnaujinimo rodikliu; šiam rodikliui įtakos gali turèti gyventojų fizinių apsilankymų skaičius, bibliotekos paslaugų prienamumą rodantis rodiklis - bibliotekos darbo valandų skaičius ir patogus arba nepatogus gyventojams lankytojų aptarnavimo laikas ir pan.

Rodiklio skaičiavimo būdas. $\mathrm{R} 3=\mathrm{A} / \mathrm{B}$, kur A - bendras SVB dokumentų (fiz. vnt.) išduočių skaičius per metus; B - aptarnaujamu gyventojų skaičius.

\section{Fondo apyvarta}

Apibrèžtis ir paskirtis. Bendras bibliotekos dokumentų (fiz. vnt.) išduočių skaičius per metus, padalytas iš bendro fonde esančių dokumentų (fiz. vnt.) skaičiaus. Rodiklis apytikriai parodo, kiek kartų per metus fondo dokumentas buvo paskolintas. Šis rodiklis padeda nustatyti, ar bibliotekos fondai atitinka aptarnaujamų gyventojų poreikius bei interesus.

Rodiklio taikymo pagrindimas. Komplektuodama fondą, biblioteka siekia ịsigyti leidinius, kurie atitiktų vartotojų poreikius ir interesus. Todèl aukštas bibliotekos fondo apyvartos rodiklis rodo, kad biblioteka 
vykdo tinkamą fondo komplektavimo politiką, taip pat - kad sukomplektuotas fondas atitinka vartotojų poreikius.

Rodiklio skaičiavimo būdas. $\mathrm{R} 4$ = A / B, kur A - bendras metinis SVB dokumentų (fiz. vnt.) išduočių skaičius; B - bendras dokumentų (fiz. vnt.) skaičius fonde.

\section{Bendras bibliotekos darbo valandu, kai biblioteka atvira vartotojui, skaičius per metus, tenkantis 1000 gyventoju}

Apibrěžtis ir paskirtis. Bendras metinis bibliotekos darbo valandų skaičius, kai biblioteka atvira vartotojui, tenkantis 1000 gyventojų. Bibliotekos darbo valandos yra valandos, kuriomis vartotojams prieinamos pagrindinès bibliotekos paslaugos, t. y. informacinis aptarnavimas ir dokumentų išduotis, darbas skaityklose.

Rodiklio taikymo pagrindimas. Bibliotekos darbo laikas yra pagrindinis bibliotekos paslaugu prieinamumo rodiklis, parodantis, kaip aptarnaujamai bendruomenei užtikrinama prieiga prie bibliotekos išteklių ir paslaugu.

Rodiklio skaičiavimo būdas. R5 = A / B x 1000, kur A - bendras SVB darbo valandu skaičius per metus, kai biblioteka atvira vartotojams; $\mathrm{B}$ - aptarnaujamų gyventojų skaičius.

\section{III dimensija. Našumas}

\section{Fondui komplektuoti skirtos lèšos 1 išduočiai}

Apibrèžtis ir paskirtis. Bibliotekos fondo komplektavimo išlaidos per finansinius metus visų formatų dokumentams ịsigyti, padalytos iš bendro išduočių skaičiaus per tą patị laikotarpị. Rodiklis ịvertina bibliotekos fondo komplektavimo išlaidas, tenkančias 1 išduočiai, ir bibliotekos fondo sudarymo politikos efektyvumą atsižvelgiant ị vartotojų poreikius (ISO 11620:2014).

Rodiklio taikymo pagrindimas. Rodiklis aktualus visoms bibliotekoms, turinčioms fizinị ir elektroninị fondus. Elektroninès laikmenos vis 
dažniau pakeičia spausdintinius dokumentus, todèl svarbu, kad bendras fondo (visų formatų dokumentų) naudojimas būtų palyginamas su bibliotekos fondo komplektavimo išlaidomis, vertinant fondo tinkamumą ir bibliotekos fondo formavimo politiką. Šis rodiklis parodo, ar biblioteka, komplektuodama fondą, įsigijo vartotojų poreikius ir interesus atitinkančius leidinius. Mažesnè rodiklio vertè rodo fondo rentabilumą - kuo įsigyjami dokumentai labiau atitinka aptarnaujamos bendruomenès poreikius, tuo didesnę jie turi paklausą ir tuo didèja jų išduotys bei fondo apyvarta. Šis rodiklis taip pat susijęs su fondo atnaujinimo rodikliu.

Rodiklio skaičiavimo būdas. $\mathrm{R} 1=\mathrm{A} / \mathrm{B}$, kur $\mathrm{A}-\mathrm{SVB}$ fondui komplektuoti skirtos lèšos per metus litais; B - SVB bendras dokumentų (fiz. vnt.) išduočių skaičius per metus.

\section{Darbuotojų darbo valandų ir valandų, per kurias biblioteka atvira lankytojams, santykis}

Apibrèžtis ir paskirtis. Lankytojus aptarnaujančių darbuotojų darbo valandų skaičius per metus, padalytas iš darbo valandų, per kurias biblioteka atvira lankytojams. Šis rodiklis parodo darbuotoju, aptarnaujančių lankytojus, darbo laiko sąnaudas teikiant paslaugas.

Rodiklio taikymo pagrindimas. Pagal BIX metodiką, kuo mažesnè šio rodiklio vertè, tuo aukštesnị vertinimą gauna biblioteka. Maža rodiklio vertè rodo efektyvų darbo organizavimą diferencijuojant darbuotojų pareigines funkcijas ir optimaliai panaudojant jų darbo laiką, todèl kuo daugiau aptarnaujantys darbuotojai skiria laiko tiesioginiam lankytojų aptarnavimui, tuo aukščiau vertinama biblioteka.

Didelè rodiklio verté, taip pat ir maža jo vertè rodo, kad bibliotekoje yra mažai etatu, todèl diferencijuoti pareigines funkcijas nèra galimybių ir lankytojų aptarnavimas organizuojamas rotacijos principu, t. y. daugumos ịvairia veikla užsiimančiu darbuotojų tam tikra darbo laiko dalis skiriama lankytojams aptarnauti, bet tai nèra pagrindinè jų veikla. Plètojant įvairias veiklas ir nesant galimybių didinti darbuotojų skaičiaus, viešosiose 
bibliotekose dažnai taikoma praktika, kai įvairios papildomos funkcijos priskiriamos jau esamoms pareigybėms. Šiuo atveju biblioteka turi ribotas galimybes užtikrinti pakankamą paslaugu pasiūlą, jų prieinamumą bei kokybę, todèl didelè šio rodiklio vertė gali nulemti mažesnes su juo susijusių rodiklių (renginių skaičius 1000 gyventojų; nepakankamai išplètotos elektroninès paslaugos ir pan.) vertes.

Rodiklio skaičiavimo būdas. $\mathrm{R} 2$ = A / B, kur A - SVB darbuotojų, aptarnaujančių lankytojus, darbo valandų skaičius per metus; B - SVB darbo valandų skaičius per metus, kai biblioteka atvira lankytojams.

\section{Apsilankymų skaičius per 1 bibliotekos darbo (kai ji atvira lanky- tojui) valandą}

Apibrèžtis ir paskirtis. Bendras apsilankymų bibliotekoje skaičius per metus, padalytas iš valandu, per kurias biblioteka atvira lankytojams, skaičiaus. Šis rodiklis parodo, kiek vidutiniškai per 1 darbo valandą (kai biblioteka yra atvira lankytojui) būna apsilankymų bibliotekoje. Šiuo atveju bibliotekos darbo valandos - tai valandos, kuriomis vartotojams prieinamos pagrindinès bibliotekos paslaugos, t. y. vyksta informacinis aptarnavimas, darbas skaityklose, išduodami dokumentai.

Rodiklio taikymo pagrindimas. Apsilankymu skaičius per 1 bibliotekos darbo (kai ji atvira lankytojui) valandą leidžia tirti naudojimosi biblioteka ypatumus: didelè šio rodiklio vertè gali rodyti ilgesnio aptarnavimo laiko (papildomų aptarnavimo valandu) poreikį, labai maža - kad darbo valandos yra nepatogios daugumai aptarnaujamos bendruomenès gyventojų. Šiam rodikliui didelę reikšmę turi aptarnaujamos bendruomenès gyventoju skaičius, jam taip pat daro ịtaką bibliotekos patalpu plotas, kompiuterizuotu darbo vietu vartotojams skaičius ir pan.

Rodiklio skaičiavimo būdas. R3 = A / B, kur A - SVB apsilankymų bibliotekoje skaičius per metus; B - SVB darbo valandų skaičius per metus, kai biblioteka atvira lankytojams. 


\section{Paprastosios 1 apsilankymui skirtos išlaidos}

Apibrèžtis ir paskirtis. Bendros paprastosios bibliotekos išlaidos per finansinius metus, padalytos iš apsilankymų bibliotekoje skaičiaus. Rodikliu siekiama nustatyti bibliotekos paslaugu kainos ir apsilankymu bibliotekoje skaičiaus santykį. Jis parodo, kiek atsieina vienas vartotojo apsilankymas bibliotekoje.

Rodiklio taikymo pagrindimas. Pagal BIX metodiką, kuo mažesnè šio rodiklio vertè, tuo aukštesnị vertinimą gauna biblioteka. Viešosios bibliotekos veikloje vartotojų aptarnavimas yra vienas svarbiausių jos veiklos prioritetų. Šis rodiklis tiesiogiai parodo finansines bibliotekos sąnaudas teikiant gyventojams paslaugas. Aukštą ịvertinimą šioje srityje gali gauti tos bibliotekos, kurių paslaugomis naudojasi daug aptarnaujamos bendruomenès gyventojų (kuo didesnis apsilankymų skaičius bibliotekoje, tuo mažesnè vieno apsilankymo kaina).

Rodiklio skaičiavimo būdas. $\mathrm{R} 4$ = A / B, kur A - paprastosios, arba eksploatavimo, SVB išlaidos per metus litais; B - bendras vartotojų fizinių apsilankymų skaičius per metus. Remiantis ISO 2789:2013, paprastosios išlaidos apima darbuotojams, nuomai, komplektavimui ir licencijoms įsigyti skiriamas išlaidas, ịrišimo, kompiuterių tinklų, telekomunikacijų, pastatų išlaikymo, turimų baldų ir ịrangos priežiūros, keitimo ir t. t. išlaidas.

\section{IV dimensija. Plètra}

\section{Fondo atnaujinimo procentas}

Apibrèžtis ir paskirtis. Bibliotekos gautų naujų dokumentų skaičius (fiz. vnt.) per metus, padalytas iš bibliotekos fonde esančių dokumentų (fiz. vnt.) skaičiaus ir padaugintas iš 100 . Rodikliu norima nustatyti, koki bibliotekos fondo procentą sudaro gauti einamujų metų dokumentai.

Rodiklio taikymo pagrindimas. Nuolat ir pakankamai atnaujinamas dokumentų fondas yra vienas svarbiausių rodiklių vertinant biblio- 
tekos galimybes tenkinti gyventojų informacinius poreikius. Pagal IFLA ir UNESCO rekomendacijas viešųjų bibliotekų fondai turi būti atnaujinti per 10 metų. Jų fondus turètų sudaryti 10 proc. dokumentų, kurie išleisti per pastaruosius 2 metus, o 5 proc. - einamujų metų leidiniai [12]. Fondo atnaujinimo rodiklis tiesiogiai priklauso nuo fondui komplektuoti skirtų lešų ir nuo fondo dydžio. Žemas rodiklis gali reikšti nepakankamą finansavimą naujiems dokumentams ịsigyti arba nepakankamai intensyvią antrinę dokumentų atranką ir per didelį (perteklinị) fondą.

Rodiklio skaičiavimo būdas. R1 = A / B x 100, kur A - SVB gautų naujų dokumentų (fiz. vnt.) skaičius per metus; B - bendras SVB fonde esančių dokumentų (fiz. vnt.) skaičius.

\section{1 darbuotojo mokymams skirtų valandų skaičius}

Apibrèžtis ir paskirtis. Mokymams skirtų valandų skaičius, padalytas iš bendro bibliotekos darbuotojų skaičiaus (asmenų skaičiaus, ne VEE). Šis rodiklis parodo, kaip aktyviai bibliotekų darbuotojai dalyvavo mokymuose per metus. Rodiklis leidžia įvertinti darbuotojų mokymo mastą.

Rodiklio taikymo pagrindimas. Šiandienëje itin sparčiai kintančioje informacinejje ir technologijų aplinkoje aukšta bibliotekos darbuotoju kompetencija yra pagrindinè prielaida tinkamai ir našiai teikti tradicines ir elektronines bibliotekos paslaugas. Todèl nuolatinis darbuotojų mokymasis ir kompetencijos atnaujinimas yra esminis sèkmingos bibliotekos veiklos veiksnys. Mokymams skirtų valandų skaičius rodo, ar bibliotekos personalas yra pasirengęs plètoti ir kurti naujas paslaugas bei užtikrinti teikiamų paslaugų kokybę.

Skaičiuojant ši rodiklį, mokymais laikomas profesinès kvalifikacijos tobulinimas: bibliotekininkystès žinių plètimas, elektroninių paslaugu diegimas, tyrimų metodika, renginių organizavimas, viešieji ryšiai, komunikacija, skaitmeninimas; bendruju kompetenciju tobulinimas - kalbu, kompiuterinio raštingumo, darbo santykių ir darbo teisès (ne specialistams), organizacijos vadybos (pvz., direktoriui ir jo pavaduotojams, pada- 
linių vadovams), psichologijos, bendravimo žinių (jeigu tai tiesiogiai nesusiję su vartotoju aptarnavimu), projektų vadybos (ne projektų vadybininkams), naudojimosi elektroninèmis paslaugomis (e. valdžia, VMI, „Sodra“, e. bankininkystė ir pan. paslaugos, nesusijusios su bibliotekos teikiamomis e. paslaugomis) ir pan. žinių tobulinimas.

Mokymai gali būti formalieji ir neformalieji. Formalusis profesines kvalifikacijos ir bendruju kompetenciju tobulinimas - tai mokomieji renginiai (paskaitos, kursai, mokomieji seminarai), kuriuose tikslingai siekiama išugdyti tam tikrus gebejjimus, yra mokymo planas, programa. Mokomuosiuose renginiuose derinama teorinès paskaitos ir pratybos, gali būti tik teorinis arba tik praktinis mokymas. Po mokymu gali būti gaunamas pažymëjimas. Neformalusis profesinès kvalifikacijos ir bendruju kompetenciju tobulinimas - stažuotès, ekskursijos ị kitas bibliotekas, seminarai, konferencijos, diskusijos, apskritieji stalai, paskaitos. Šiuose renginiuose klausomasi pranešimų, dažnai dalyviui turinčių tik pažintinę informacinę vertę.

Rodiklio skaičiavimo būdas. $\mathrm{R} 2=\mathrm{A} / \mathrm{B}$, kur A - mokymams skirtų valandų skaičius per metus, B - SVB darbuotojų skaičius (asmenų skaičius, ne VEE).

\section{Nepaprastosios išlaidos 1 gyventojui}

Apibrèžtis ir paskirtis. Bibliotekos nepaprastosios išlaidos per metus, padalytos iš aptarnaujamų gyventojų skaičiaus. Šis rodiklis parodo bibliotekos infrastruktūros gerinimo ir plètros galimybes.

Rodiklio taikymo pagrindimas. Investavimas ị bibliotekos infrastruktūros gerinimą yra būtinas, priešingu atveju biblioteka tampa nepatraukli aptarnaujamai bendruomenei. Remiantis ISO 2789:2013, nepaprastosioms išlaidoms priskiriamos nereguliarios investicijos biblioteku infrastruktūrai gerinti ir jos plètrai, t. y. statybai ir renovacijai, remontui, sklypams ir kitam ilgalaikiam turtui įsigyti, kompiuterinei ir programinei įrangai atnaujinti ar ịsigyti. Šių investicijų dydis parodo bibliotekos ištekliu bei paslaugų plètros galimybes ir bibliotekos pasirengimą pokyčiams. 
Rodiklio skaičiavimo būdas. $\mathrm{R} 3$ = A / B, kur A - nepaprastosios SVB išlaidos per metus litais, $\mathrm{B}$ - aptarnaujamų gyventojų skaičius.

\section{Bibliotekų grupavimas}

Gauti SVB rezultatai grupuojami pagal konkrečios bibliotekos aptarnaujamos bendruomenès dydị. Bibliotekos aptarnaujamų gyventojų skaičiumi naudojamasi apskaičiuojant daugelį rodiklių, todèl jie yra pakankamai patikimi ir leidžia objektyviau įvertinti kiekvienos bibliotekos veiklos rezultatus, lyginant juos su kitų tos pačios grupès biblioteku veiklos rodikliais. Pagal aptarnaujamų gyventojų skaičių SVB skirstomos ị 6 grupes (žr. 1 lentelę).

1 lentelè. Biblioteku grupavimas pagal aptarnaujamu gyventoju skaičiu [1]

\begin{tabular}{|l|l|}
\hline grupé & Mažiau negu 5000 gyventojų \\
1 grupé & Nuo 5000 iki 15000 gyventojų \\
\hline 2 grupé & Nuo 15000 iki 30000 gyventojų \\
3 grupé & Nuo 30000 iki 50000 gyventojų \\
4 grupé & Nuo 50000 iki 100000 gyventojų \\
\hline 5 grupé & Nuo 100000 gyventojų \\
\hline
\end{tabular}

\section{Procentilių skaičiavimas}

Suskirsčius bibliotekas ị grupes, visi tolesni skaičiavimai atliekami atskirai kiekvienoje grupëje. Nustatant kiekvienos bibliotekos poziciją kitu tos grupès bibliotekų atžvilgiu, kiekvienam rodikliui skaičiuojamas procentilis. Tai yra skaičius tarp 0 ir 1 . Biblioteka, turinti mažiausią konkretaus rodiklio vertę, gauna procentili 0,00 , o turinti didžiausią vertę - procentili 1,00. Visos kitos bibliotekos skirstomos tarp šių dviejų skaičių: pvz., 0,5 procentilio turinti biblioteka yra grupès, kuriai ji priskirta, viduryje, t. y. 50 proc. visu biblioteku turi mažesnę, 50 proc. - didesnę vertę. Procentilis 0,85 reiškia, kad 85 proc. visų tos grupès bibliotekų turi mažesnę, o 15 proc. - didesnę vertę. Jeigu kelių bibliotekų tam tikri rodikliai yra vienodi, 
šios SVB gauna vienodą to rodiklio procentili, o žemiau esančių rodiklių procentiliai pasislenka per tiek punktų, kiek yra vienodų šio rodiklių verčių.

Gavus vienodą procentilių sumą, kiekvienoje dimensijoje atsižvelgiama ì vieną iš rodiklių, leidžiančių nustatyti bibliotekos pirmumą, - kuo didesnẻ tokio rodiklio vertè (procentilis), tuo aukštesnëje pozicijoje yra biblioteka:

I dimensijoje - renginių skaičius 1000 gyventojų;

II dimensijoje - bendras bibliotekos darbo valandų (kai biblioteka atvira vartotojui) skaičius per metus, tenkantis 1000 gyventoju;

III dimensijoje - paprastosios 1 apsilankymui skirtos išlaidos;

IV dimensijoje - fondo atnaujinimo procentas.

\section{Specialieji rodikliai}

Vertinant BIX rodiklio dydi, paprastai vadovaujamasi taisykle „kuo vertė didesnè, tuo geriau“, tačiau yra keletas tikslinių rodiklių efektyvumo nustatymo išimčių. III dimensijos rodikliai: fondui komplektuoti skirtos lèsos 1 iśduočiai; darbuotoju darbo valandu ir valandu, per kurias biblioteka atvira lankytojams, santykis ir paprastosios 1 apsilankymui skirtos išlaidos yra invertinami atvirkštine tvarka: mažiausia vertẻ gauna didžiausią ịvertinimą (1,00 procentilis), o didžiausia vertè - mažiausią procentili $(0,00)$.

Apskaičiavus visu vienos dimensijos rodiklių procentilius, jie yra sumuojami ir dalijami iš šios dimensijos rodikliu skaičiaus. Gautas rezultatas vèl perskaičiuojamas i procentilius, pagal kuriuos yra nustatomas galutinis bibliotekos procentilis ir reitingas.

2 lentelè. Biblioteku reitingavimas [1]

\begin{tabular}{|c|l|l|}
$\begin{array}{c}\text { Eil. } \\
\text { Nr. }\end{array}$ & \multicolumn{1}{|c|}{ Grupé } & \multicolumn{1}{c|}{ Turinys } \\
\hline 1. & Aukščiausia grupé (auksinè) & $\begin{array}{l}\text { Viršutiniame trečdalyje esančios bibliotekos, ku- } \\
\text { rių procentilis per } 0,66\end{array}$ \\
\hline 2. & Vidurinè grupè (šviesiai mèlyna) & $\begin{array}{l}\text { Viduriniame trečdalyje esančios bibliotekos, kurių } \\
\text { procentilis tarp } 0,33 \text { ir } 0,66\end{array}$ \\
\hline 3. & $\begin{array}{l}\text { Žemiausia grupé (tamsiai } \\
\text { mélyna) }\end{array}$ & $\begin{array}{l}\text { Apatiniame trečdalyje esančios bibliotekos, kurių } \\
\text { procentilis iki } 0,32\end{array}$ \\
\hline
\end{tabular}


Aukščiausioje grupejje esančioms bibliotekoms skiriama viena žvaigždè $(\star)$, esančioms vidurinëje grupëje - pusè žvaigždès ( $\)$. Kiekviena biblioteka gali surinkti daugiausia 4 žvaigždes, jeigu visose 4 dimensijose ji yra aukščiausioje (auksinëje) grupeje.

\subsubsection{BIX duomenys ir kokybès valdymas}

Bibliotekų reitingavimas pagal BIX metodiką yra konkurencingas jis vykdomas remiantis akivaizdžiais duomenimis; BIX duomenų kokybès kontrolè atliekama naudojant išsamią trijų etapų procedūrą. BIX indeksas pagerina kokybės vadybos metodų supratimą ir taikymą viešosiose ir akademinèse bibliotekose. Šis indeksas pats savaime neinterpretuoja ir neviešina bibliotekos rezultatu, neapibrèžia standartu, nepristato misijos, strateginès plètros ar valdymo tikslų - tai turi padaryti patys bibliotekos darbuotojai.

Biblioteku veiklos vertinimas pagal BIX metodiką yra ciklinis, tikslų siekimu pagrịstas procesas. Pirmu etapu yra apibrěžiami tikslai ir nustatomi standartai, pagal kuriuos sprendžiama apie veiklą, dokumentuojami procesai, renkami kiekvienam rodikliui būtini bibliotekos veiklos duomenys; antru etapu rodiklių duomenys yra lyginami su standartais, tam tikro laikotarpio vidurkiais, jeigu reikia, ị rodiklius pažvelgiama "giliau“, daromi papildomi tyrimai; trečiame etape rezultatai aiškinami, lyginami su bibliotekos tikslais, priimami atitinkami sprendimai (žr. 2 pav.).

Vokietijoje BIX programos dalyviai (BIX indeksas pradètas naudoti 1999 m.) pateikè didelị skaičių formaliụjų ir neformaliųjų iniciatyvų, kai BIX duomenys padejo jas igyvendinti. Diuseldorfo administracinio regiono Šiaurès Reino-Vestfalijos (tankiausiai apgyvendintas Vokietijos kraštas) viešosios bibliotekos pirmą kartą istorijoje įkūrẻ regioninę tarpbibliotekinę lyginamąją grupę (1998 m.), o po ketverių metu 16 iš šių bibliotekų mažų, vidutinių ir didelių - ịsteigè kokybès valdymo darbo grupę. Be šio projekto, bibliotekose yra sukurtas vartotojo poreikiu modelis, kuriame lyginamos bibliotekų pagrindinès kokybės strategijos. 7 iš šių bibliotekų 
nusprendè būti sertifikuotos pagal ISO 9000 standartą. 2006 metais jos gavo ISO 9001 atitikties sertifikatą.

Dauguma BIX projekto dalyvių BIX rezultatais naudojasi jas finansuojančioms institucijoms pranešdamos apie savo stipriąsias ir silpnąsias ypatybes: aukštų rezultatų pasiekusios bibliotekos paskelbia apie laimëjimus; bibliotekos, kurių rezultatai nėra teigiami, siekia išspręsti iškilusias problemas, gaudamos geresnị finansavimą. Dalyvavimas BIX projekte ir strateginis rezultatų panaudojimas negarantuoja sékmès: finansuojančių ìstaigu reakcija yra ịvairi - nuo nežinojimo iki draudimo naudoti rezultatus viešiesiems ryšiams, tačiau gali būti gautas ir papildomas finansavimas ar sutikimas statyti naują bibliotekos pastatą. BIX indeksas vis dažniau pasitelkiamas tose bibliotekose, su kurių veikla susiję sprendimų prièmèjai ir finansuojančios institucijos reikalauja turèti veiksnią matavimo priemonę, kuri ir ateityje galètų padèti vertinti proceso kokybę, poveiki ir rezultatus.

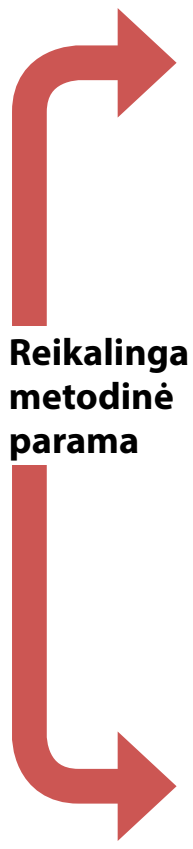

\section{1 etapas. Tikslų nustatymas}

Atsižvelgiama į vartotoju lūkesčius

Nustatomi paslaugu standartai

Procesai (eiga) dokumentuojami

\section{2 etapas. Veiklos kontrolè}

Rodiklių rezultatai lyginami su standartais, tam tikro laikotarpio vidurkiais

| rodiklius žvelgiama „giliau“, jeigu reikia, atliekami papildomi tyrimai

\section{3 etapas. Analizè ir sprendimų prièmimas}

Surenkama papildomy duomeny

Analizuojami rezultatai

Priimami sprendimai (žiūrima ne vien ị BIX rezultatus)

2 pav. BIX duomenu ir kokybes vadyba [16] 


\subsection{BIX metodikos pritaikymo rezultatai Lietuvos savivaldybių viešujų bibliotekų sistemose (SVBS)}

Tyrimo imtis ir statistikos duomenų rinkimas. Šalies SVB buvo suskirstytos i 5 grupes pagal aptarnaujamos teritorijos gyventojų skaičių. Tyrime dalyvavo visos 60 SVB (iš viso 1281 biblioteka).

3 lentelè. Biblioteku 1 grupe (gyventoju skaičius nuo 5 iki 15 000)

\begin{tabular}{|c|c|c|c|}
\hline $\begin{array}{l}\text { Eil. } \\
\text { Nr. }\end{array}$ & Apskritis & SVB pavadinimas & $\begin{array}{c}\text { Gyventojų skaičius } \\
2013 \text { m. pabaigoje [2 šaltinis] }\end{array}$ \\
\hline 1. & Kauno & Birštono SVB* & 4370 \\
\hline 2. & Marijampolès & Kalvarijos SVB & 11635 \\
\hline 3. & Marijampolès & Kazlų Rūdos SVB & 12638 \\
\hline 4. & Klaipedos & Neringos SVB* & 2757 \\
\hline 5. & Tauragès & Pagègių SVB & 8931 \\
\hline 6. & Telšių & Rietavo SVB & 8264 \\
\hline
\end{tabular}

* Birštono ir Neringos SVB buvo priskirtos 1 grupei, nors jų aptarnaujamų teritorijų gyventojų skaičius nesiekia 5 tūkst. Šalyje yra tik dvi bibliotekų 0 grupei priskirtinos SVB (gyventojų skaičius iki 5000). Reitinguoti dvi SVB nèra prasmès.

4 lentelè. Biblioteku 2 grupé (gyventojų skaičius nuo 15000 iki 30 000)

\begin{tabular}{|c|c|c|c|}
\hline $\begin{array}{l}\text { Eil. } \\
\text { Nr. }\end{array}$ & Apskritis & SVB pavadinimas & $\begin{array}{c}\text { Gyventojų skaičius } 2013 \mathrm{~m} \text {. } \\
\text { pabaigoje [2 šaltinis] }\end{array}$ \\
\hline 1. & Alytaus & Alytaus r. SVB & 27356 \\
\hline 2. & Šiaulių & Akmenès r. SVB & 21685 \\
\hline 3. & Utenos & Anykščių r. SVB & 26898 \\
\hline 4. & Panevėžio & Biržų r. SVB & 26479 \\
\hline 5. & Alytaus & Druskininkų SVB & 20947 \\
\hline 6. & Vilniaus & Elektrėnų SVB & 24236 \\
\hline 7. & Utenos & Ignalinos r. SVB & 17145 \\
\hline 8. & Šiaulių & Joniškio r. SVB & 24310 \\
\hline 9. & Tauragès & Jurbarko r. SVB & 28675 \\
\hline 10. & Panevėžio & Kupiškio r. SVB & 19067 \\
\hline 11. & Alytaus & Lazdijų r. SVB & 21251 \\
\hline 12. & Utenos & Molètų r. SVB & 19590 \\
\hline 13. & Klaipèdos & Palangos m. SVB & 15367 \\
\hline 14. & Šiaulių & Pakruojo r. SVB & 21997 \\
\hline 15. & Panevėžio & Pasvalio r. SVB & 26663 \\
\hline 16. & Kauno & Prienų r. SVB & 28522 \\
\hline 17. & Klaipèdos & Skuodo r. SVB & 18912 \\
\hline
\end{tabular}




\begin{tabular}{|c|l|l|c|}
\hline $\begin{array}{c}\text { Eil. } \\
\text { Nr. }\end{array}$ & \multicolumn{1}{|c|}{ Apskritis } & \multicolumn{1}{|c|}{ SVB pavadinimas } & $\begin{array}{c}\text { Gyventojų skaičius 2013 m. } \\
\text { pabaigoje [2 šaltinis] }\end{array}$ \\
\hline 18. & Tauragès & Šilalès r. SVB & 25200 \\
\hline 19. & Vilniaus & Širvintų r. SVB & 16597 \\
\hline 20. & Vilniaus & Švenčionių r. SVB & 26270 \\
\hline 21. & Alytaus & Varėnos r. SVB & 23961 \\
\hline 22. & Utenos & Visagino SVB & 20635 \\
\hline 23. & Utenos & Zarasų r. SVB & 17318 \\
\hline
\end{tabular}

5 lentelè. Biblioteku 3 grupé (gyventoju skaičius nuo 30000 iki 50 000)

\begin{tabular}{|c|c|c|c|}
\hline $\begin{array}{l}\text { Eil. } \\
\text { Nr. }\end{array}$ & Apskritis & SVB pavadinimas & $\begin{array}{c}\text { Gyventojų skaičius } 2013 \mathrm{~m} \text {. } \\
\text { pabaigoje [2 šaltinis] }\end{array}$ \\
\hline 1. & Kauno & Jonavos r. SVB & 44481 \\
\hline 2. & Kauno & Kaišiadorių r. SVB & 32370 \\
\hline 3. & Šiaulių & Kelmès r. SVB & 30303 \\
\hline 4. & Klaipèdos & Kretingos r. SVB & 40147 \\
\hline 5. & Panevėžio & Panevėžio r. SVB & 37494 \\
\hline 6. & Telšių & Plungès r. SVB & 36524 \\
\hline 7. & Šiaulių & Radviliškio r. SVB & 39705 \\
\hline 8. & Kauno & Raseinių r. SVB & 35496 \\
\hline 9. & Panevėžio & Rokiškio r. SVB & 32754 \\
\hline 10. & Marijampolès & Šakių r. SVB & 30852 \\
\hline 11. & Vilniaus & Šalčininkų r. SVB & 33191 \\
\hline 12. & Šiaulių & Šiaulių r. SVB & 42217 \\
\hline 13. & Klaipèdos & Šilutès r. SVB & 42473 \\
\hline 14. & Tauragès & Tauragès r. SVB & 41877 \\
\hline 15. & Telšių & Telšių r. SVB & 44633 \\
\hline 16. & Vilniaus & Trakų r. SVB & 33558 \\
\hline 17. & Vilniaus & Ukmergès r. SVB & 37561 \\
\hline 18. & Utenos & Utenos r. SVB & 41018 \\
\hline 19. & Marijampolès & Vilkaviškio r. SVB & 40258 \\
\hline
\end{tabular}

6 lentelè. Bibliotekų 4 grupe (gyventojų skaičius nuo 50000 iki 100 000)

\begin{tabular}{|c|c|c|c|}
\hline $\begin{array}{l}\text { Eil. } \\
\text { Nr. }\end{array}$ & Apskritis & SVB pavadinimas & $\begin{array}{c}\text { Gyventojų skaičius } 2013 \mathrm{~m} \text {. } \\
\text { pabaigoje [2 šaltinis] }\end{array}$ \\
\hline 1. & Alytaus & Alytaus m. SVB & 56364 \\
\hline 2. & Kauno & Kauno r. SVB & 87168 \\
\hline 3. & Kauno & Kèdainių r. SVB & 50906 \\
\hline 4. & Klaipèdos & Klaipèdos r. SVB & 52140 \\
\hline 5. & Marijampolès & Marijampolès SVB & 58714 \\
\hline 6. & Telšių & Mažeikių r. SVB & 56143 \\
\hline 7. & Panevèžio & Panevėžio $\mathrm{m}$. VB & 96345 \\
\hline 8. & Vilniaus & Vilniaus r. SVB & 95052 \\
\hline
\end{tabular}


7 lentelè. Biblioteku 5 grupè (gyventoju skaičius per 100 000)

\begin{tabular}{|c|l|l|c|}
$\begin{array}{c}\text { Eil. } \\
\text { Nr. }\end{array}$ & \multicolumn{1}{|c|}{ Apskritis } & \multicolumn{1}{|c|}{ SVB pavadinimas } & $\begin{array}{c}\text { Gyventojų skaičius 2013 m. } \\
\text { pabaigoje [2 šaltinis] }\end{array}$ \\
\hline 1. & Kauno & Kauno m. SVB & 304097 \\
\hline 2. & Klaipėdos & Klaipèdos m. SVB & 157350 \\
\hline 3. & Šiaulių & Šiaulių m. SVB & 105653 \\
\hline 4. & Vilniaus & Vilniaus m. SVB & 539939 \\
\hline
\end{tabular}

\subsubsection{Bibliotekų grupių rodiklių vertès ir reitingas}

\section{I dimensija. Ištekliai ir infrastruktūra}

Šioje dalyje vertinami I dimensijos rodikliai, rodantys bibliotekos išteklių ir infrastruktūros atitiktị bei prieinamumą aptarnaujamiems gyventojams (naudojami 6 rodikliai); pateikiami šios dimensijos bibliotekų 1, 2, 3, 4, 5 grupių rezultatai bei jų reitingai.

1 grupè. 8 lentelëje pateikiama 1 grupès I dimensijos 6 rodikliu verčių išraiškos procentiliais suma. Skaičiuojant galutinị I dimensijos procentili ir nustatant biblioteku reitingą, ị aukščiausią grupę pateko ir po žvaigždę gavo Birštono ir Pagėgių SVB (žr. 10 lentelę). Pagal BIX metodiką šių SVB teikiami ištekliai ir infrastruktūra yra vertinami geriausiai. Birštono SVB beveik pagal visus I dimensijos rodiklius užèmė aukščiausias pozicijas: rodiklių vartotoju aptarnavimo patalpu plotas $\left(\mathrm{m}^{2}\right)$, tenkantis 1000 gyventoju; profesionaliu bibliotekininku (viso etato elvivalentais - VEE) skaičius 1000 gyventoju procentiliai - 1,00; o kitu rodikliu procentiliai - 0,80.

Pagėgiu SVB rodikliu interneto seansu skaičius 1 gyventojui; renginiu skaičius 1000 gyventoju procentiliai - 1,00, o kitų rodikliu procentiliai svyruoja nuo 0,40 iki 0,60.

I vidurinę grupę pateko ir po pusę žvaigždès gavo Neringos ir Kalvarijos SVB.

Žemiausioje grupëje liko Rietavo ir Kazlų Rūdos SVB. 
8 lentelè. I dimensija. 1 grupès bibliotekų ištekliu ir infrastruktūros rodiklių verčiu procentiliais suma

\begin{tabular}{|c|l|c|c|c|c|c|c|c|}
\hline \multirow{2}{*}{$\begin{array}{l}\text { Eil. } \\
\text { Nr. }\end{array}$} & SVB pavadinimas & $\begin{array}{c}\text { Procentilis } \\
\text { 1 ro- } \\
\text { diklis }\end{array}$ & $\begin{array}{c}\mathbf{2} \text { ro- } \\
\text { diklis }\end{array}$ & $\begin{array}{c}\text { 3 ro- } \\
\text { diklis }\end{array}$ & $\begin{array}{c}\text { 4 ro- } \\
\text { diklis }\end{array}$ & $\begin{array}{c}\text { 5 ro- } \\
\text { diklis }\end{array}$ & $\begin{array}{c}\text { 6 ro- } \\
\text { diklis }\end{array}$ & $\begin{array}{c}\text { Bendra } \\
\text { procenti- } \\
\text { lių suma }\end{array}$ \\
\hline 1. & Birštono SVB & 0,80 & 1,00 & 1,00 & 0,80 & 0,80 & 0,80 & 5,20 \\
\hline 2. & Kalvarijos SVB & 0,40 & 0,40 & 0,60 & 0,40 & 0,60 & 0,40 & 2,80 \\
\hline 3. & Kazlu Rūdos SVB & 0,00 & 0,00 & 0,00 & 0,00 & 0,40 & 0,20 & 0,60 \\
\hline 4. & Neringos SVB & 1,00 & 0,80 & 0,80 & 0,20 & 0,20 & 0,00 & 3,00 \\
\hline 5. & Pagègių SVB & 0,60 & 0,60 & 0,40 & 0,60 & 1,00 & 1,00 & 4,20 \\
\hline 6. & Rietavo SVB & 0,20 & 0,20 & 0,00 & 1,00 & 0,00 & 0,60 & 2,00 \\
\hline
\end{tabular}

1 rodiklis - dokumentu (fiz. vnt.) skaičius 1 gyventojui;

2 rodiklis - vartotoju aptarnavimo patalpu plotas $\left(\mathrm{m}^{2}\right)$, tenkantis 1000 gyventoju;

3 rodiklis - profesionaliu bibliotekininku (viso etato ekvivalentais - VEE) skaicius 1000 gyventoju; 4 rodiklis - viešosios prieigos kompiuterizuotu darbo vietu (vartotojams) skaičius 10000 gyventojų; 5 rodiklis - interneto seansu skaičius 1 gyventojui;

6 rodiklis - renginiu skaičius 1000 gyventojų.

9 lentelè. I dimensija. 1 grupès biblioteku bendrasis ištekliu ir infrastruktüros rodikliu verčiu procentilis

\begin{tabular}{|c|l|c|c|c|}
\hline $\begin{array}{c}\text { Eil. } \\
\text { Nr. }\end{array}$ & \multicolumn{1}{|c|}{ SVB pavadinimas } & $\begin{array}{c}\text { Procentilių } \\
\text { suma }\end{array}$ & $\begin{array}{c}\text { Procentilių suma, } \\
\text { padalyta iš 6 }\end{array}$ & $\begin{array}{c}\text { Galutinis } \\
\text { procentilis }\end{array}$ \\
\hline 1. & Kazlų Rūdos SVB & 0,60 & 0,100 & 0,00 \\
\hline 2. & Rietavo SVB & 2,00 & 0,333 & 0,20 \\
\hline 3. & Kalvarijos SVB & 2,80 & 0,467 & 0,40 \\
\hline 4. & Neringos SVB & 3,00 & 0,500 & 0,60 \\
\hline 5. & Pagègiu SVB & 4,20 & 0,700 & 0,80 \\
\hline 6. & Birštono SVB & 5,20 & 0,867 & 1,00 \\
\hline
\end{tabular}

10 lentelè. I dimensija. 1 grupès biblioteku ištekliu ir infrastruktūros įvertinimas

\begin{tabular}{|c|c|c|c|c|}
\hline $\begin{array}{l}\text { Eil. } \\
\text { Nr. }\end{array}$ & SVB pavadinimas & Procentilių suma & $\begin{array}{l}\text { Procentilių suma, } \\
\text { padalyta iš } 6\end{array}$ & $\begin{array}{l}\text { Galutinis } \\
\text { procentilis }\end{array}$ \\
\hline 1. & Birštono SVB & 5,20 & 0,867 & 1,00 \\
\hline 2. & Pagėgių SVB & 4,20 & 0,700 & 0,80 \\
\hline 3. & Neringos SVB & 3,00 & 0,500 & 0,60 \\
\hline 4. & Kalvarijos SVB & 2,80 & 0,467 & 0,40 \\
\hline 5. & Rietavo SVB & 2,00 & 0,333 & 0,20 \\
\hline 6. & Kazlų Rūdos SVB & 0,60 & 0,100 & 0,00 \\
\hline
\end{tabular}

2 grupè. Šioje biblioteku grupejje geriausiai yra vertinami Zarasu, Lazdiju, Skuodo, Molètu, Širvintu, Ignalinos, Pakruojo ir Pasvalio rajonu 
SVB ištekliai ir infrastruktūra, šios SVB pateko i̇ auksinę grupę ir pelnẻ po žvaigždę (žr. 13 lentelę). Aukščiausias pozicijas užèmė Zarasų rajono SVB. Ši biblioteka pirmauja pagal tris rodiklius: rodikliu vartotoju aptarnavimo patalpu plotas $\left(\mathrm{m}^{2}\right)$, tenkantis 1000 gyventoju; profesionaliu bibliotekininku (viso etato ekvivalentais - VEE) skaičius 1000 gyventoju; viěsosios prieigos kompiuterizuotu darbo vietu (vartotojams) skaičius 10000 gyventoju procentiliai - 1,00, o likusių rodiklių procentiliai svyruoja nuo 0,82 iki 0,95 (11, 13 lentelès).

I vidurinę grupę pateko ir po pusę žvaigždès pelnè Alytaus, Kupiškio, Varènos, Anykščiu, Jurbarko, Biržų rajonų SVB ir Palangos SVB (13 lentelè).

Žemiausioje grupëje - Joniškio, Švenčioniu, Šilalès, Akmenès, Prienų rajonų SVB ir Elektrènų, Druskininkų, Visagino SVB. Remiantis BIX metodika, visu 2 grupès biblioteku pozicijos yra geresnès nei Visagino $\mathrm{SVB}$, kurios galutinis procentilis yra 0,00 .

11 lentelè. I dimensija. 2 grupès biblioteku ištekliu ir infrastruktūros rodikliu verčiu procentiliais suma

\begin{tabular}{|c|c|c|c|c|c|c|c|c|}
\hline \multirow[b]{2}{*}{$\begin{array}{l}\text { Eil. } \\
\text { Nr. }\end{array}$} & \multirow[b]{2}{*}{ SVB pavadinimas } & \multicolumn{6}{|c|}{ Procentilis } & \multirow{2}{*}{$\begin{array}{l}\text { Bendra } \\
\text { procenti- } \\
\text { lių suma }\end{array}$} \\
\hline & & $\begin{array}{l}1 \text { ro- } \\
\text { diklis }\end{array}$ & $\begin{array}{l}2 \text { ro- } \\
\text { diklis }\end{array}$ & $\begin{array}{l}3 \text { ro- } \\
\text { dilklis }\end{array}$ & $\begin{array}{l}4 \text { ro- } \\
\text { diklis }\end{array}$ & $\begin{array}{l}5 \text { ro- } \\
\text { dilklis }\end{array}$ & $\begin{array}{l}6 \text { ro- } \\
\text { diklis }\end{array}$ & \\
\hline 1. & Alytaus r. SVB & 1,00 & 0,73 & 0,55 & 0,68 & 0,59 & 0,36 & 3,91 \\
\hline 2. & Akmenès r. SVB & 0,55 & 0,09 & 0,14 & 0,23 & 0,14 & 0,45 & 1,60 \\
\hline 3. & Anykščių r. SVB & 0,36 & 0,68 & 0,59 & 0,45 & 0,45 & 0,91 & 3,44 \\
\hline 4. & Biržų r. SVB & 0,41 & 0,36 & 0,41 & 0,55 & 0,09 & 0,14 & 1,96 \\
\hline 5. & Druskininkų SVB & 0,32 & 0,05 & 0,05 & 0,05 & 0,27 & 0,09 & 0,83 \\
\hline 6. & Elektrėnų SVB & 0,09 & 0,18 & 0,18 & 0,36 & 0,41 & 0,55 & 1,77 \\
\hline 7. & Ignalinos SVB & 0,77 & 0,86 & 0,95 & 0,59 & 0,82 & 0,27 & 4,26 \\
\hline 8. & Joniškio r. SVB & 0,18 & 0,23 & 0,36 & 0,14 & 0,36 & 0,68 & 1,95 \\
\hline 9. & Jurbarko r. SVB & 0,59 & 0,64 & 0,09 & 0,27 & 0,32 & 0,23 & 2,14 \\
\hline 10. & Kupiškio r. SVB & 0,82 & 0,82 & 0,77 & 0,32 & 0,55 & 0,50 & 3,78 \\
\hline 11. & Lazdijų r. SVB & 0,91 & 0,91 & 0,73 & 0,95 & 0,50 & 0,73 & 4,73 \\
\hline 12. & Molètų r. SVB & 0,45 & 0,95 & 0,68 & 0,91 & 0,68 & 0,77 & 4,44 \\
\hline 13. & Palangos SVB & 0,64 & 0,41 & 0,64 & 0,09 & 0,64 & 0,00 & 2,42 \\
\hline 14. & Pakruojo r. SVB & 0,68 & 0,45 & 0,50 & 0,73 & 1,00 & 0,86 & 4,22 \\
\hline 15. & Pasvalio r. SVB & 0,73 & 0,77 & 0,45 & 0,82 & 0,77 & 0,64 & 4,18 \\
\hline 16. & Prienų r. SVB & 0,00 & 0,27 & 0,27 & 0,41 & 0,23 & 0,32 & 1,50 \\
\hline 17. & Skuodo r. SVB & 0,95 & 0,59 & 0,86 & 0,86 & 0,86 & 0,59 & 4,71 \\
\hline
\end{tabular}




\begin{tabular}{|c|c|c|c|c|c|c|c|c|}
\hline \multirow[b]{2}{*}{$\begin{array}{l}\text { Eil. } \\
\text { Nr. }\end{array}$} & \multirow[b]{2}{*}{ SVB pavadinimas } & \multicolumn{6}{|c|}{ Procentilis } & \multirow{2}{*}{$\begin{array}{l}\text { Bendra } \\
\text { procenti- } \\
\text { lių suma }\end{array}$} \\
\hline & & $\begin{array}{l}1 \text { ro- } \\
\text { diklis }\end{array}$ & $\begin{array}{l}2 \text { ro- } \\
\text { diklis }\end{array}$ & $\begin{array}{l}3 \text { ro- } \\
\text { diklis }\end{array}$ & $\begin{array}{l}4 \text { ro- } \\
\text { diklis }\end{array}$ & $\begin{array}{l}5 \text { ro- } \\
\text { diklis }\end{array}$ & $\begin{array}{l}6 \text { ro- } \\
\text { diklis }\end{array}$ & \\
\hline 18. & Šilalès r. SVB & 0,14 & 0,32 & 0,23 & 0,64 & 0,18 & 0,18 & 1,69 \\
\hline 19. & Širvintų r. SVB & 0,50 & 0,50 & 0,91 & 0,77 & 0,73 & 1,00 & 4,41 \\
\hline 20. & Švenčionių r. SVB & 0,23 & 0,14 & 0,32 & 0,18 & 0,05 & 0,95 & 1,87 \\
\hline 21. & Varènos r. SVB & 0,27 & 0,55 & 0,82 & 0,50 & 0,91 & 0,41 & 3,46 \\
\hline 22. & Visagino SVB & 0,05 & 0,00 & 0,00 & 0,00 & 0,00 & 0,05 & 0,10 \\
\hline 23. & Zarasų r. SVB & 0,86 & 1,00 & 1,00 & 1,00 & 0,95 & 0,82 & 5,63 \\
\hline
\end{tabular}

1 rodiklis - dokumentu (fiz. vnt.) skaičius 1 gyventojui;

2 rodiklis - vartotoju aptarnavimo patalpu plotas $\left(m^{2}\right)$, tenkantis 1000 gyventoju;

3 rodiklis - profesionaliu bibliotekininku (viso etato ekvivalentais - VEE) skaičius 1000 gyventoju; 4 rodiklis - viešsios prieigos kompiuterizuotu darbo vietu (vartotojams) skaičius 10000 gyventoju; 5 rodiklis - interneto seansu skaičius 1 gyventojui;

6 rodiklis - renginiu skaičius 1000 gyventoju.

12 lentelè. I dimensija. 2 grupès biblioteku bendrasis ištekliu ir infrastruktūros rodikliu verčiu procentilis

\begin{tabular}{|c|c|c|c|c|}
\hline $\begin{array}{l}\text { Eil. } \\
\text { Nr. }\end{array}$ & SVB pavadinimas & $\begin{array}{l}\text { Procentilių } \\
\text { suma }\end{array}$ & $\begin{array}{l}\text { Procentilių suma, } \\
\text { padalyta iš } 6\end{array}$ & $\begin{array}{l}\text { Galutinis pro- } \\
\text { centilis }\end{array}$ \\
\hline 1. & Visagino SVB & 0,10 & 0,017 & 0,00 \\
\hline 2. & Druskininkų SVB & 0,83 & 0,138 & 0,05 \\
\hline 3. & Prienų r. SVB & 1,50 & 0,250 & 0,09 \\
\hline 4. & Akmenės r. SVB & 1,60 & 0,267 & 0,14 \\
\hline 5. & Šilalès r. SVB & 1,69 & 0,282 & 0,18 \\
\hline 6. & Elektrėnų SVB & 1,77 & 0,295 & 0,23 \\
\hline 7. & Švenčionių r. SVB & 1,87 & 0,312 & 0,27 \\
\hline 8. & Joniškio r. SVB & 1,95 & 0,325 & 0,32 \\
\hline 9. & Biržų r. SVB & 1,96 & 0,327 & 0,36 \\
\hline 10. & Jurbarko r. SVB & 2,14 & 0,357 & 0,41 \\
\hline 11. & Palangos SVB & 2,42 & 0,403 & 0,45 \\
\hline 12. & Anykščių r. SVB & 3,44 & 0,573 & 0,50 \\
\hline 13. & Varènos r. SVB & 3,46 & 0,577 & 0,55 \\
\hline 14. & Kupiškio r. SVB & 3,78 & 0,630 & 0,59 \\
\hline 15. & Alytaus r. SVB & 3,91 & 0,652 & 0,64 \\
\hline 16. & Pasvalio r. SVB & 4,18 & 0,697 & 0,68 \\
\hline 17. & Pakruojo r. SVB & 4,22 & 0,703 & 0,73 \\
\hline 18. & Ignalinos r. SVB & 4,26 & 0,710 & 0,77 \\
\hline 19. & Širvintų r. SVB & 4,41 & 0,735 & 0,82 \\
\hline 20. & Molètų r. SVB & 4,44 & 0,740 & 0,86 \\
\hline 21. & Skuodo r. SVB & 4,71 & 0,785 & 0,91 \\
\hline 22. & Lazdijų r. SVB & 4,73 & 0,788 & 0,95 \\
\hline 23. & Zarasų r. SVB & 5,63 & 0,938 & 1,00 \\
\hline
\end{tabular}


13 lentelè. I dimensija. 2 grupès biblioteku ištekliu ir infrastruktūros įvertinimas

\begin{tabular}{|c|c|c|c|c|}
\hline Eil. Nr. & SVB pavadinimas & Procentiliu suma & $\begin{array}{c}\text { Procentilių suma, } \\
\text { padalyta iš } 6\end{array}$ & $\begin{array}{l}\text { Galutinis } \\
\text { procentilis }\end{array}$ \\
\hline 1. & Zarasų r. SVB & 5,63 & 0,938 & 1,00 \\
\hline 2. & Lazdijų r. SVB & 4,73 & 0,788 & 0,95 \\
\hline 3. & Skuodo r. SVB & 4,71 & 0,785 & 0,91 \\
\hline 4. & Molètų r. SVB & 4,44 & 0,740 & 0,86 \\
\hline 5. & Širvintų r. SVB & 4,41 & 0,735 & 0,82 \\
\hline 6. & Ignalinos r. SVB & 4,26 & 0,710 & 0,77 \\
\hline 7. & Pakruojo r. SVB & 4,22 & 0,703 & 0,73 \\
\hline 8. & Pasvalio r. SVB & 4,18 & 0,697 & 0,68 \\
\hline 9. & Alytaus r. SVB & 3,91 & 0,652 & 0,64 \\
\hline 10. & Kupiškio r. SVB & 3,78 & 0,630 & 0,59 \\
\hline 11. & Varénos r. SVB & 3,46 & 0,577 & 0,55 \\
\hline 12. & Anykščių r. SVB & 3,44 & 0,573 & 0,50 \\
\hline 13. & Palangos SVB & 2,42 & 0,403 & 0,45 \\
\hline 14. & Jurbarko r. SVB & 2,14 & 0,357 & 0,41 \\
\hline 15. & Biržų r. SVB & 1,96 & 0,327 & 0,36 \\
\hline 16. & Joniškio r. SVB & 1,95 & 0,325 & 0,32 \\
\hline 17. & Švenčionių r. SVB & 1,87 & 0,312 & 0,27 \\
\hline 18. & Elektrėnų SVB & 1,77 & 0,295 & 0,23 \\
\hline 19. & Šilalès r. SVB & 1,69 & 0,282 & 0,18 \\
\hline 20. & Akmenės r. SVB & 1,60 & 0,267 & 0,14 \\
\hline 21. & Prienų r. SVB & 1,50 & 0,250 & 0,09 \\
\hline 22. & Druskininkų SVB & 0,83 & 0,138 & 0,05 \\
\hline 23. & Visagino SVB & 0,10 & 0,017 & 0,00 \\
\hline
\end{tabular}

3 grupè. It aukščiausią grupę pateko ir geriausiai ịvertintos Rokiškio, Panevėžio, Kelmès, Radviliškio, Utenos, Šalčininkų ir Kaišiadorių rajonų SVB (žr.16 lentelę).

Rokiškio rajono SVB yra šios grupès biblioteku reitingo viršuje: rodikliu dokumentu (fiz. vnt.) skaicius 1 gyventojui; profesionaliu bibliotekininku (viso etato ekvivalentais - VEE) skaičius 1000 gyventoju; viešosios prieigos kompiuterizuotu darbo vietu (vartotojams) skaičius 10000 gyventoju; interneto seansu skaičius 1 gyventojui ir renginiu skaičius 1000 gyventojui procentiliai - 1,00, o likusio rodiklio vertinimai - 0,94 procentilio. Utenos rajono SVB pirmavo pagal rodiklio vartotoju aptarnavimo patalpu plotas $\left(m^{2}\right)$, tenkantis 1000 gyventoju vertę (14 lentelè). 
İ vidurinę grupę pateko ir po pusę žvaigždès gavo Ukmergès, Šilutės, Vilkaviškio, Raseinių, Tauragès, Šakių rajonų SVB.

Žemiausioje grupèje - Šiaulių, Trakų, Telšių, Kretingos, Jonavos, Plungès rajonų SVB. İ šią grupę pateko bibliotekos, kurių procentilis yra iki 0,32. Remiantis BIX metodika, visu 3 grupès biblioteku pozicijos yra geresnès nei Plungès rajono SVB, kurios galutinis procentilis yra 0,00 (žr. 14, 15, 16 lenteles).

14 lentelè. I dimensija. 3 grupès biblioteku ištekliu ir infrastruktūros rodikliu verčiu procentiliais suma

\begin{tabular}{|c|c|c|c|c|c|c|c|c|}
\hline \multirow{2}{*}{$\begin{array}{l}\text { Eil. } \\
\text { Nr. }\end{array}$} & \multirow[b]{2}{*}{ SVB pavadinimas } & \multicolumn{6}{|c|}{ Procentilis } & \multirow{2}{*}{$\begin{array}{l}\text { Bendra } \\
\text { procenti- } \\
\text { lių suma }\end{array}$} \\
\hline & & $\begin{array}{l}1 \text { ro- } \\
\text { diklis }\end{array}$ & $\begin{array}{l}2 \text { ro- } \\
\text { diklis }\end{array}$ & $\begin{array}{l}3 \text { ro- } \\
\text { dilklis }\end{array}$ & $\begin{array}{l}4 \text { ro- } \\
\text { dilklis }\end{array}$ & $\begin{array}{l}5 \text { ro- } \\
\text { diklis }\end{array}$ & $\begin{array}{l}6 \text { ro- } \\
\text { diklis }\end{array}$ & \\
\hline 1. & Jonavos r. SVB & 0,06 & 0,00 & 0,00 & 0,00 & 0,61 & 0,11 & 0,78 \\
\hline 2. & Kaišiadorių r. SVB & 0,39 & 0,78 & 0,39 & 0,78 & 0,78 & 0,50 & 3,62 \\
\hline 3. & Kelmès r. SVB & 0,44 & 0,61 & 0,56 & 0,67 & 0,89 & 0,94 & 4,11 \\
\hline 4. & Kretingos r. SVB & 0,11 & 0,22 & 0,22 & 0,22 & 0,22 & 0,33 & 1,32 \\
\hline 5. & Panevėžio r. SVB & 0,67 & 0,72 & 0,94 & 0,94 & 0,94 & 0,83 & 5,04 \\
\hline 6. & Plungès r. SVB & 0,00 & 0,11 & 0,11 & 0,17 & 0,33 & 0,06 & 0,78 \\
\hline 7. & Radviliškio r. SVB & 0,89 & 0,89 & 0,50 & 0,39 & 0,83 & 0,56 & 4,06 \\
\hline 8. & Raseinių r. SVB & 0,56 & 0,67 & 0,44 & 0,28 & 0,39 & 0,67 & 3,01 \\
\hline 9. & Rokiškio r. SVB & 1,00 & 0,94 & 1,00 & 1,00 & 1,00 & 1,00 & 5,94 \\
\hline 10. & Šakių r. SVB & 0,28 & 0,39 & 0,61 & 0,33 & 0,17 & 0,72 & 2,50 \\
\hline 11. & Šalčininkų r. SVB & 0,94 & 0,56 & 0,89 & 0,72 & 0,44 & 0,39 & 3,94 \\
\hline 12. & Šiaulių r. SVB & 0,83 & 0,28 & 0,17 & 0,11 & 0,06 & 0,61 & 2,06 \\
\hline 13. & Šilutès r. SVB & 0,22 & 0,44 & 0,67 & 0,89 & 0,67 & 0,22 & 3,11 \\
\hline 14. & Tauragès r. SVB & 0,33 & 0,33 & 0,83 & 0,61 & 0,11 & 0,44 & 2,65 \\
\hline 15. & Telšių r. SVB & 0,50 & 0,17 & 0,06 & 0,50 & 0,28 & 0,17 & 1,68 \\
\hline 16. & Trakų r. SVB & 0,61 & 0,06 & 0,28 & 0,06 & 0,56 & 0,28 & 1,85 \\
\hline 17. & Ukmergès r. SVB & 0,17 & 0,83 & 0,78 & 0,44 & 0,50 & 0,78 & 3,50 \\
\hline 18. & Utenos r. SVB & 0,72 & 1,00 & 0,72 & 0,83 & 0,72 & 0,00 & 3,99 \\
\hline 19. & Vilkaviškio r. SVB & 0,78 & 0,50 & 0,33 & 0,56 & 0,00 & 0,89 & 3,06 \\
\hline
\end{tabular}

1 rodiklis - dokumentu (fiz. vnt.) skaičius 1 gyventojui;

2 rodiklis - vartotoju aptarnavimo patalpu plotas $\left(\mathrm{m}^{2}\right)$, tenkantis 1000 gyventoju;

3 rodiklis - profesionaliu bibliotekininku (viso etato ekvivalentais-VEE) skaicius 1000 gyventoju;

4 rodiklis - viešosios prieigos kompiuterizuotu darbo vietu (vartotojams) skaičius 10000 gyventoju;

5 rodiklis - interneto seansu skaičius 1 gyventojui;

6 rodiklis - renginiu skaičius 1000 gyventoju. 
15 lentelè. I dimensija. 3 grupès biblioteku bendrasis ištekliu ir infrastruktūros rodikliu verčiu procentilis

\begin{tabular}{|c|c|c|c|c|}
\hline $\begin{array}{l}\text { Eil. } \\
\text { Nr. }\end{array}$ & SVB pavadinimas & $\begin{array}{l}\text { Procentiliu } \\
\text { suma }\end{array}$ & $\begin{array}{l}\text { Procentilių suma, } \\
\text { padalyta iš } 6\end{array}$ & $\begin{array}{l}\text { Galutinis } \\
\text { procentilis }\end{array}$ \\
\hline 1. & Jonavos r. SVB & 0,78 & 0,130 & 0,00 \\
\hline 2. & Plungès r. SVB & 0,78 & 0,130 & 0,00 \\
\hline 3. & Kretingos r. SVB & 1,32 & 0,220 & 0,11 \\
\hline 4. & Telšių r. SVB & 1,68 & 0,280 & 0,17 \\
\hline 5. & Trakų r. SVB & 1,85 & 0,308 & 0,22 \\
\hline 6. & Šiaulių r. SVB & 2,06 & 0,343 & 0,24 \\
\hline 7. & Šakių r. SVB & 2,50 & 0,417 & 0,33 \\
\hline 8. & Tauragès r. SVB & 2,65 & 0,442 & 0,39 \\
\hline 9. & Raseinių r. SVB & 3,01 & 0,502 & 0,44 \\
\hline 10. & Vilkaviškio r. SVB & 3,06 & 0,510 & 0,50 \\
\hline 11. & Šilutès r. SVB & 3,11 & 0,518 & 0,56 \\
\hline 12. & Ukmergès r. SVB & 3,50 & 0,583 & 0,61 \\
\hline 13. & Kaišiadorių r. SVB & 3,62 & 0,603 & 0,67 \\
\hline 14. & Šalčininkų r. SVB & 3,94 & 0,657 & 0,72 \\
\hline 15. & Utenos r. SVB & 3,99 & 0,665 & 0,78 \\
\hline 16. & Radviliškio r. SVB & 4,06 & 0,677 & 0,83 \\
\hline 17. & Kelmès r. SVB & 4,11 & 0,685 & 0,89 \\
\hline 18. & Panevėžio r. SVB & 5,04 & 0,840 & 0,94 \\
\hline 19. & Rokiškio r. SVB & 5,94 & 0,990 & 1,00 \\
\hline
\end{tabular}

16 lentelè. I dimensija. 3 grupès bibliotekų ištekliu ir infrastruktūros įvertinimas

\begin{tabular}{|c|l|c|c|c|c|}
\hline Eil. & \multicolumn{1}{|c|}{ SVB pavadinimas } & $\begin{array}{c}\text { Procentilių } \\
\text { suma }\end{array}$ & $\begin{array}{c}\text { Procentilių suma, } \\
\text { padalyta iš 6 }\end{array}$ & $\begin{array}{c}\text { Galutinis } \\
\text { procentilis }\end{array}$ \\
\hline N. & Rokiškio r. SVB & 5,94 & 0,990 & 1,00 & $\star$ \\
\hline 2. & Panevěžio r. SVB & 5,04 & 0,840 & 0,94 & $\star$ \\
\hline 3. & Kelmès r. SVB & 4,11 & 0,685 & 0,89 & $\star$ \\
\hline 4. & Radviliškio r. SVB & 4,06 & 0,677 & 0,83 & $\star$ \\
\hline 5. & Utenos r. SVB & 3,99 & 0,665 & 0,78 & $\star$ \\
\hline 6. & Šalčininkų r. SVB & 3,94 & 0,657 & 0,72 & $\star$ \\
\hline 7. & Kaišiadorių r. SVB & 3,62 & 0,603 & 0,67 & $\star$ \\
\hline
\end{tabular}




\begin{tabular}{|c|c|c|c|c|}
\hline $\begin{array}{l}\text { Eil. } \\
\text { Nr. }\end{array}$ & SVB pavadinimas & $\begin{array}{l}\text { Procentilių } \\
\text { suma }\end{array}$ & $\begin{array}{c}\text { Procentilių suma, } \\
\text { padalyta iš } 6\end{array}$ & $\begin{array}{l}\text { Galutinis } \\
\text { procentilis }\end{array}$ \\
\hline 8. & Ukmergès r. SVB & 3,50 & 0,583 & 0,61 \\
\hline 9. & Šilutès r. SVB & 3,11 & 0,518 & 0,56 \\
\hline 10. & Vilkaviškio r. SVB & 3,06 & 0,510 & 0,50 \\
\hline 11. & Raseiniu r. SVB & 3,01 & 0,502 & 0,44 \\
\hline 12. & Tauragès r. SVB & 2,65 & 0,442 & 0,39 \\
\hline 13. & Šakių r. SVB & 2,50 & 0,417 & 0,33 \\
\hline 14. & Šiaulių r. SVB & 2,06 & 0,343 & 0,24 \\
\hline 15. & Trakų r. SVB & 1,85 & 0,308 & 0,22 \\
\hline 16. & Telšių r. SVB & 1,68 & 0,280 & 0,17 \\
\hline 17. & Kretingos r. SVB & 1,32 & 0,220 & 0,11 \\
\hline 18. & Jonavos r. SVB & 0,78 & 0,130 & 0,00 \\
\hline 19. & Plungès r. SVB & 0,78 & 0,130 & 0,00 \\
\hline
\end{tabular}

4 grupè. İ aukščiausią grupę pateko ir po žvaigždę pelnè Kèdainių, Klaipèdos rajonų ir Marijampolès SVB (̌̌r. 19 lentelę). Šios grupès reitingo viršuje atsidūrẻ Kèdainių rajono SVB, gavusi aukščiausius įvertinimus pagal 6 šios dimensijos rodiklius: rodikliu dokumentu (fiz. vnt.) skaičius 1 gyventojui; vartotoju aptarnavimo patalpu plotas $\left(\mathrm{m}^{2}\right)$, tenkantis 1000 gyventoju; profesionaliu bibliotekininku (viso etato ekvivalentais - VEE) skaičius 1000 gyventoju; viešosios prieigos kompiuterizuotu darbo vietu (vartotojams) skaičius 10000 gyventoju; renginiu skaičius 1000 gyventoju ir interneto seansu skaičius 1 gyventojui procentiliai - 1,00.

İ vidurinę grupę pateko ir po pusę žvaigždès pelnè Kauno ir Mažeikių rajonų SVB.

Žemiausioje grupëje liko Vilniaus rajono ir Alytaus bei Panevėžio miestų SVB. Visų šios grupès bibliotekų pozicijos yra geresnès negu Panevėžio miesto $S V B$, kurios bendrasis I dimensijos procentilis lygus 0,00 (žr. 17, 19 lenteles). 
17 lentelè. I dimensija. 4 grupès bibliotekų ištekliu ir infrastruktūros rodikliu verčiu procentiliais suma

\begin{tabular}{|c|c|c|c|c|c|c|c|c|}
\hline \multirow{2}{*}{$\begin{array}{l}\text { Eil. } \\
\text { Nr. }\end{array}$} & \multirow{2}{*}{ SVB pavadinimas } & \multicolumn{6}{|c|}{ Procentilis } & \multirow{2}{*}{$\begin{array}{c}\text { Bendra } \\
\text { procentiliu } \\
\text { suma }\end{array}$} \\
\hline & & $\begin{array}{l}1 \text { ro- } \\
\text { diklis }\end{array}$ & $\begin{array}{l}2 \text { ro- } \\
\text { diklis }\end{array}$ & $\begin{array}{l}3 \text { ro- } \\
\text { diklis }\end{array}$ & $\begin{array}{l}4 \text { ro- } \\
\text { diklis }\end{array}$ & $\begin{array}{l}5 \text { ro- } \\
\text { diklis }\end{array}$ & $\begin{array}{l}6 \text { ro- } \\
\text { diklis }\end{array}$ & \\
\hline 1. & Alytaus m. SVB & 0,14 & 0,14 & 0,14 & 0,14 & 0,00 & 0,00 & 0,56 \\
\hline 2. & Kauno r. SVB & 0,57 & 0,43 & 0,29 & 0,43 & 0,71 & 0,86 & 3,29 \\
\hline 3. & Kèdainių r. SVB & 1,00 & 1,00 & 1,00 & 1,00 & 1,00 & 1,00 & 6,00 \\
\hline 4. & Klaipėdos r. SVB & 0,86 & 0,57 & 0,86 & 0,86 & 0,57 & 0,71 & 4,43 \\
\hline 5. & Marijampolès SVB & 0,43 & 0,86 & 0,71 & 0,71 & 0,43 & 0,57 & 3,71 \\
\hline 6. & Mažeikių r. SVB & 0,71 & 0,71 & 0,57 & 0,57 & 0,29 & 0,29 & 3,14 \\
\hline 7. & Panevėžio m. SVB & 0,00 & 0,00 & 0,00 & 0,00 & 0,14 & 0,14 & 0,28 \\
\hline 8. & Vilniaus r. SVB & 0,29 & 0,29 & 0,43 & 0,29 & 0,86 & 0,43 & 2,59 \\
\hline
\end{tabular}

1 rodiklis - dokumentu (fiz. vnt.) skaičius 1 gyventojui;

2 rodiklis - vartotoju aptarnavimo patalpu plotas $\left(\mathrm{m}^{2}\right)$, tenkantis 1000 gyventoju;

3 rodiklis - profesionaliu bibliotekininku (viso etato ekvivalentais - VEE) skaičius 1000 gyventoju; 4 rodiklis - viešsios prieigos kompiuterizuotu darbo vietu (vartotojams) skaičius 10000 gyventoju; 5 rodiklis - interneto seansu skaičius 1 gyventojui;

6 rodiklis - renginiu skaičius 1000 gyventojų.

18 lentelè. I dimensija. 4 grupes biblioteku bendrasis ištekliu ir infrastruktūros rodikliu. verčiu procentilis

\begin{tabular}{|c|l|c|c|c|}
\hline $\begin{array}{c}\text { Eil. } \\
\text { Nr. }\end{array}$ & \multicolumn{1}{|c|}{ SVB pavadinimas } & $\begin{array}{c}\text { Procentilių } \\
\text { suma }\end{array}$ & $\begin{array}{c}\text { Procentilių suma, } \\
\text { padalyta iš 6 }\end{array}$ & $\begin{array}{c}\text { Galutinis } \\
\text { procentilis }\end{array}$ \\
\hline 1. & Panevėžio m. SVB & 0,28 & 0,047 & 0,00 \\
\hline 2. & Alytaus m. SVB & 0,56 & 0,093 & 0,14 \\
\hline 3. & Vilniaus r. SVB & 2,59 & 0,432 & 0,29 \\
\hline 4. & Mažeikių r. SVB & 3,14 & 0,523 & 0,43 \\
\hline 5. & Kauno r. SVB & 3,29 & 0,548 & 0,57 \\
\hline 6. & Marijampolès SVB & 3,71 & 0,618 & 0,71 \\
\hline 7. & Klaipèdos r. SVB & 4,43 & 0,738 & 0,86 \\
\hline 8. & Kèdainių r. SVB & 6,00 & 1,000 & 1,00 \\
\hline
\end{tabular}

19 lentelè. I dimensija. 4 grupès bibliotekų ištekliu ir infrastruktūros įvertinimas

\begin{tabular}{|c|c|c|c|c|}
\hline $\begin{array}{l}\text { Eil. } \\
\text { Nr. }\end{array}$ & SVB & $\begin{array}{l}\text { Procentiliu } \\
\text { suma }\end{array}$ & $\begin{array}{c}\text { Procentilių suma, } \\
\text { padalyta iš } 6\end{array}$ & $\begin{array}{l}\text { Galutinis } \\
\text { procentilis }\end{array}$ \\
\hline 1. & Këdainių r. SVB & 6,00 & 1,000 & 1,00 \\
\hline 2. & Klaipèdos r. SVB & 4,43 & 0,738 & 0,86 \\
\hline 3. & Marijampolès SVB & 3,71 & 0,618 & 0,71 \\
\hline
\end{tabular}




\begin{tabular}{|c|c|c|c|c|}
\hline $\begin{array}{l}\text { Eil. } \\
\text { Nr. }\end{array}$ & SVB & $\begin{array}{l}\text { Procentilių } \\
\text { suma }\end{array}$ & $\begin{array}{l}\text { Procentilių suma, } \\
\text { padalyta iš } 6\end{array}$ & $\begin{array}{l}\text { Galutinis } \\
\text { procentilis }\end{array}$ \\
\hline 4. & Kauno r. SVB & 3,29 & 0,548 & 0,57 \\
\hline 5. & Mažeikių r. SVB & 3,14 & 0,523 & 0,43 \\
\hline 6. & Vilniaus r. SVB & 2,59 & 0,432 & 0,29 \\
\hline 7. & Alytaus m. SVB & 0,56 & 0,093 & 0,14 \\
\hline 8. & Panevėžio m. SVB & 0,28 & 0,047 & 0,00 \\
\hline
\end{tabular}

5 grupè. Šioje grupejje yra tik 4 SVB. I aukščiausiąją grupę pateko Šiaulių m. ir Klaipèdos m. SVB (žr. 22 lentelę). Jos abi pirmavo pagal tris rodiklius: Šiauliu miesto SVB rodiklių profesionaliu bibliotekininku (viso etato ekvivalentais - VEE) skaičius 1000 gyventoju; interneto seansu skaičius 1 gyventojui ir renginiu skaičius 1000 gyventoju procentiliai yra 1,00, o Klaipèdos miesto SVB užèmè pirmaujančias pozicijas pagal rodiklių dokumentu (fiz. vnt.) skaičius 1 gyventojui; vartotoju aptarnavimo patalpu plotas $\left(m^{2}\right)$, tenkantis 1000 gyventoju; viešosios prieigos kompiuterizuotu darbo vietu (vartotojams) skaičius 10000 gyventoju (20 lentelè).

I vidurinę grupę pateko ir pusę žvaigždès pelnè Kauno miesto SVB. Žemiausioje grupèje liko Vilniaus miesto SVB (žr. 22 lentelę).

20 lentelè. I dimensija. 5 grupès biblioteku ištekliu ir infrastruktūros rodikliu verčiu procentiliais suma

\begin{tabular}{|c|c|c|c|c|c|c|c|c|}
\hline \multirow[b]{2}{*}{$\begin{array}{l}\text { Eil. } \\
\text { Nr. }\end{array}$} & \multirow[b]{2}{*}{ SVB pavadinimas } & \multicolumn{6}{|c|}{ Procentilis } & \multirow{2}{*}{$\begin{array}{l}\text { Bendra } \\
\text { procenti- } \\
\text { lių suma }\end{array}$} \\
\hline & & $\begin{array}{l}1 \text { ro- } \\
\text { dilklis }\end{array}$ & $\begin{array}{l}2 \text { ro- } \\
\text { diklis }\end{array}$ & $\begin{array}{l}3 \text { ro- } \\
\text { dilklis }\end{array}$ & $\begin{array}{l}4 \text { ro- } \\
\text { diklis }\end{array}$ & $\begin{array}{l}5 \text { ro- } \\
\text { dilklis }\end{array}$ & $\begin{array}{l}6 \text { ro- } \\
\text { diklis }\end{array}$ & \\
\hline 1. & Kauno m. SVB & 0,33 & 0,33 & 0,67 & 0,33 & 0,67 & 0,33 & 2,66 \\
\hline 2. & Klaipedos m. SVB & 1,00 & 1,00 & 0,33 & 1,00 & 0,33 & 0,67 & 4,33 \\
\hline 3. & Šiaulių m. SVB & 0,67 & 0,67 & 1,00 & 0,67 & 1,00 & 1,00 & 5,01 \\
\hline 4. & Vilniaus $\mathrm{m}$. SVB & 0,00 & 0,00 & 0,00 & 0,00 & 0,00 & 0,00 & 0,00 \\
\hline
\end{tabular}

1 rodiklis - dokumentu (fiz. vnt.) skaičius 1 gyventojui;

2 rodiklis - vartotoju aptarnavimo patalpu plotas $\left(\mathrm{m}^{2}\right)$, tenkantis 1000 gyventoju;

3 rodiklis - profesionaliu bibliotekininku (viso etato ekvivalentais - VEE) skaicius 1000 gyventoju;

4 rodiklis - viešosios prieigos kompiuterizuotu darbo vietu (vartotojams) skaičius 10000 gyventoju;

5 rodiklis - interneto seansu skaičius 1 gyventojui;

6 rodiklis - renginiu skaičius 1000 gyventoju. 
21 lentelè. I dimensija. 5 grupès biblioteku bendrasis ištekliu ir infrastruktūros rodikliu verčiu procentilis

\begin{tabular}{|c|l|c|c|c|}
\hline $\begin{array}{c}\text { Eil. } \\
\text { Nr. }\end{array}$ & \multicolumn{1}{|c|}{ SVB pavadinimas } & $\begin{array}{c}\text { Procentilių } \\
\text { suma }\end{array}$ & $\begin{array}{c}\text { Procentilių suma, } \\
\text { padalyta iš 6 }\end{array}$ & $\begin{array}{c}\text { Galutinis } \\
\text { procentilis }\end{array}$ \\
\hline 1. & Vilniaus m. SVB & 0,00 & 0,000 & 0,00 \\
\hline 2. & Kauno m. SVB & 2,66 & 0,443 & 0,33 \\
\hline 3. & Klaipédos m. SVB & 4,33 & 0,722 & 0,67 \\
\hline 4. & Šiaulių m. SVB & 5,01 & 0,835 & 1,00 \\
\hline
\end{tabular}

22 lentelè. I dimensija. 5 grupès bibliotekų ištekliu ir infrastruktūros įvertinimas

\begin{tabular}{|c|c|c|c|c|}
\hline $\begin{array}{l}\text { Eil. } \\
\text { Nr. }\end{array}$ & SVB pavadinimas & $\begin{array}{l}\text { Procentilių } \\
\text { suma }\end{array}$ & $\begin{array}{c}\text { Procentilių suma, } \\
\text { padalyta iš } 6\end{array}$ & $\begin{array}{l}\text { Galutinis } \\
\text { procentilis }\end{array}$ \\
\hline 1. & Šiaulių m. SVB & 5,01 & 0,835 & 1,00 \\
\hline 2. & Klaipėdos m. SVB & 4,33 & 0,722 & 0,67 \\
\hline 3. & Kauno m. SVB & 2,66 & 0,443 & 0,33 \\
\hline 4. & Vilniaus $\mathrm{m}$. SVB & 0,00 & 0,000 & 0,00 \\
\hline
\end{tabular}

\section{II dimensija. Naudojimasis biblioteka}

Šioje dimensijoje vertinami 5 rodikliai, atspindintys, kaip aptarnaujami gyventojai naudojasi ištekliais ir infrastruktūra, kurie buvo ịvertinti I dimensijoje; pateikiami II dimensijos biblioteku 1, 2, 3, 4, 5 grupių rezultatai bei jų reitingai.

1 grupè. 23 lentelèje yra pateikiama II dimensijos 5 rodiklių verčių procentiliais suma. Skaičiuojant galutinị II dimensijos procentilị ir nustatant bibliotekų reitinga, ị aukščiausią grupę pateko ir žvaigždę pelnẻ Birštono SVB (žr. 25 lentelę): pagal 4 iš 5 rodiklių ji užėmė aukščiausias pozicijas (procentiliai - 1,00); o rodiklio fondo apyvarta procentilis - 0,80. Be to, Birštono SVB ir I dimensijoje pateko ị auksinę grupę ir gavo žvaigždę, todèl galima teigti, kad bibliotekų turimi ištekliai ir infrastruktūra daro tiesioginę įtaką bendruomenès naudojimuisi biblioteka (žr. 10, 25 lenteles). 
I vidurinę grupę pateko ir po pusę žvaigždès gavo Pagėgiu, Neringos ir Kazlų Rūdos SVB (žr. 25 lentelę). Šioje dimensijoje kelioms bibliotekoms surinkus vienodą galutini procentili, pirmumo teisè atitenka bibliotekai, kurios rodiklio bendras bibliotekos darbo valandu, kai biblioteka atvira vartotojui, skaičius per metus, tenkantis 1000 gyventoju procentilis yra aukštesnis. Tiek Pagègiu, tiek Neringos SVB bendrasis II dimensijos procentilis lygus 0,60, tačiau galutiniame bibliotekų reitinge Pagègių SVB yra aukščiau, nes jos šio rodiklio procentilis yra 0,80 , o Neringos SVB 0,60 (žr. 24, 25 lenteles).

Žemiausioje grupèje liko Kalvarijos ir Rietavo SVB. Pagal BIX metodiką naudojimasis turimais ištekliais ir infrastruktūra šiose bibliotekose vertinamas žemiausiai (žr. 25 lentelę).

23 lentelè. II dimensija. 1 grupes biblioteku naudojimosi biblioteka rodikliu verčiu procentiliais suma

\begin{tabular}{|c|l|c|c|c|c|c|c|}
\hline \multirow{2}{*}{$\begin{array}{l}\text { Eil. } \\
\text { Nr. }\end{array}$} & \multirow{6}{*}{ SVB pavadinimas } & $\begin{array}{c}\text { 1 ro- } \\
\text { diklis }\end{array}$ & $\begin{array}{c}\text { 2 ro- } \\
\text { diklis }\end{array}$ & $\begin{array}{c}\text { 3 ro- } \\
\text { diklis }\end{array}$ & $\begin{array}{c}\text { 4 ro- } \\
\text { diklis }\end{array}$ & $\begin{array}{c}\text { 5 ro- } \\
\text { diklis }\end{array}$ & $\begin{array}{c}\text { Bendra } \\
\text { procenti- } \\
\text { lių suma }\end{array}$ \\
\hline 1. & Birštono SVB & 1,00 & 1,00 & 1,00 & 0,80 & 1,00 & 4,80 \\
\hline 2. & Kalvarijos SVB & 0,40 & 0,00 & 0,20 & 0,60 & 0,20 & 1,40 \\
\hline 3. & Kazlų Rūdos SVB & 0,20 & 0,25 & 0,60 & 1,00 & 0,00 & 2,05 \\
\hline 4. & Neringos SVB & 0,60 & 0,75 & 0,80 & 0,00 & 0,60 & 2,75 \\
\hline 5. & Pagègių SVB & 0,80 & n. d. & 0,40 & 0,20 & 0,80 & 2,20 \\
\hline 6. & Rietavo SVB & 0,00 & 0,00 & 0,00 & 0,40 & 0,40 & 0,80 \\
\hline
\end{tabular}

1 rodiklis - apsilankymu (fiziniu) skaičius 1 gyventojui;

2 rodiklis - virtualiu apsilankymu skaičius 1 gyventojui;

3 rodiklis - dokumentu išduočiu (fiz. vnt.) skaičius 1 gyventojui;

4 rodiklis - fondo apyvarta;

5 rodiklis - bendras bibliotekos darbo valandu, kai biblioteka atvira vartotojui, skaičius per metus, tenkantis 1000 gyventoju. 
24 lentelè. II dimensija. 1 grupès biblioteku bendrasis naudojimosi biblioteka rodikliu verčiu procentilis

\begin{tabular}{|c|l|c|c|c|}
\hline Eil. & \multicolumn{1}{|c|}{ SVB pavadinimas } & Procentilių suma & $\begin{array}{c}\text { Procentilių suma, } \\
\text { padalyta iš 5 }\end{array}$ & $\begin{array}{c}\text { Galutinis } \\
\text { procentilis }\end{array}$ \\
\hline 1. & Rietavo SVB & 0,80 & 0,160 & 0,00 \\
\hline 2. & Kalvarijos SVB & 1,40 & 0,280 & 0,20 \\
\hline 3. & Kazlų Rūdos SVB & 2,05 & 0,410 & 0,40 \\
\hline 4. & Neringos SVB & 2,75 & 0,550 & 0,60 \\
\hline 5. & Pagègių SVB* & 2,20 & 0,550 & 0,60 \\
\hline 6. & Birštono SVB & 4,80 & 0,960 & 1,00 \\
\hline
\end{tabular}

* Pagegiu SVB procentiliu suma padalyta iš 4, nes 2 rodikliui (virtualių apsilankymų skaičius 1 gyventojui) apskaičiuoti nera duomenu (n. d.).

25 lentelè. II dimensija. 1 grupes biblioteku naudojimosi biblioteka ivvertinimas

\begin{tabular}{|c|c|c|c|c|}
\hline $\begin{array}{l}\text { Eil. } \\
\text { Nr. }\end{array}$ & SVB pavadinimas & Procentilių suma & $\begin{array}{l}\text { Procentilių suma, } \\
\text { padalyta iš } 5\end{array}$ & $\begin{array}{l}\text { Galutinis } \\
\text { procentilis }\end{array}$ \\
\hline 1. & Birštono SVB & 4,80 & 0,960 & 1,00 \\
\hline 2. & Pagègių SVB & 2,20 & 0,550 & 0,60 \\
\hline 3. & Neringos SVB & 2,75 & 0,550 & 0,60 \\
\hline 4. & Kazlų Rūdos SVB & 2,05 & 0,410 & 0,40 \\
\hline 5. & Kalvarijos SVB & 1,40 & 0,280 & 0,20 \\
\hline 6. & Rietavo SVB & 0,80 & 0,160 & 0,00 \\
\hline
\end{tabular}

2 grupè. İ aukščiausią grupę pateko ir po žvaigždę pelnè 8 SVB: Pasvalio, Alytaus, Zarasu, Varẻnos, Ignalinos, Anykščių, Širvintų ir Joniškio rajonų SVB (žr. 28 lentelę). 4 SVB - Pasvalio, Zarasų, Ignalinos bei Širvintų rajonų - ir I dimensijoje buvo patekusios ị auksinę grupę ir pelniusios po žvaigždę. Alytaus, Varẻnos, Anykščių rajonų SVB I dimensijoje pateko į vidurinę grupę ir pelnè po pusę žvaigždès. Taigi šie rezultatai patvirtina teigini, kad naudojimasis biblioteka tiesiogiai priklauso nuo turimų bibliotekos išteklių ir infrastruktūros (žr. 13, 28 lenteles). Zarasų ir Varènos rajonų SVB surinkus vienodą galutini II dimensijos procentili - 0,86, bibliotekų reitinge Zarasų rajono SVB atsidūrè aukščiau, nes šios bibliotekos rodiklio bendras bibliotekos darbo valandu, kai biblioteka atvira vartotojui, skaičius per metus, tenkantis 1000 gyventoju procentilis lygus 0,82, o Varẻnos rajono SVB - 0,59 (žr. 27, 28 lenteles). 
İ vidurinę grupę pateko ir po pusę žvaigždès igijo 7 SVB: Molètu, Kupiškio, Prienų, Skuodo, Jurbarko rajonų ir Elektrènų, Palangos SVB.

Žemiausioje grupëje liko 8 SVB: Šilalès, Biržų, Pakruojo, Lazdijų, Švenčionių, Akmenės rajonų ir Druskininkų, Visagino SVB. 5 iš šiu SVB Šilalès, Švenčionių, Akmenès rajonų ir Druskininkų, Visagino SVB - ir I dimensijoje buvo žemiausioje vietoje. Galutinis pagal BIX metodiką gautas rezultatas yra toks: II dimensijoje 95 proc. biblioteku yra geresneje pozicijoje negu Akmenès rajono SVB ir visų grupès bibliotekų pozicija yra geresnè negu Visagino SVB (žr. 13, 28 lenteles).

26 lentelè. II dimensija. 2 grupès biblioteku naudojimosi biblioteka rodikliu verčiu procentiliais suma

\begin{tabular}{|c|c|c|c|c|c|c|c|}
\hline \multirow{2}{*}{$\begin{array}{l}\text { Eil } \\
\text { Nr. }\end{array}$} & \multirow[b]{2}{*}{ SVB pavadinimas } & \multicolumn{5}{|c|}{ Procentilis } & \multirow{2}{*}{$\begin{array}{l}\text { Bendra } \\
\text { procenti- } \\
\text { lių suma }\end{array}$} \\
\hline & & $\begin{array}{l}1 \text { ro- } \\
\text { diklis }\end{array}$ & $\begin{array}{l}2 \text { ro- } \\
\text { diklis }\end{array}$ & $\begin{array}{l}3 \text { ro- } \\
\text { diklis }\end{array}$ & $\begin{array}{l}4 \text { ro- } \\
\text { diklis }\end{array}$ & $\begin{array}{l}5 \text { ro- } \\
\text { diklis }\end{array}$ & \\
\hline 1. & Alytaus r. SVB & 1,00 & 0,10 & 1,00 & 0,86 & 0,95 & 3,91 \\
\hline 2. & Akmenės r. SVB & 0,05 & 0,19 & 0,05 & 0,05 & 0,18 & 0,52 \\
\hline 3. & Anykščių r. SVB & 0,64 & 0,48 & 0,64 & 0,82 & 0,55 & 3,13 \\
\hline 4. & Biržų r. SVB & 0,23 & 0,67 & 0,36 & 0,41 & 0,36 & 2,03 \\
\hline 5. & Druskininkų SVB & 0,14 & 0,71 & 0,09 & 0,18 & 0,09 & 1,21 \\
\hline 6 & Elektrėnų SVB & 0,55 & 0,86 & 0,23 & 0,68 & 0,14 & 2,46 \\
\hline 7. & Ignalinos r. SVB & 0,95 & 0,14 & 0,95 & 0,73 & 0,73 & 3,50 \\
\hline 8. & Joniškio r. SVB & 0,50 & 0,29 & 0,73 & 1,00 & 0,41 & 2,93 \\
\hline 9. & Jurbarko r. SVB & 0,27 & 0,24 & 0,86 & 0,77 & 0,27 & 2,41 \\
\hline 10 & Kupiškio r. SVB & 0,36 & 0,62 & 0,77 & 0,32 & 0,64 & 2,71 \\
\hline 11. & Lazdijų r. SVB & 0,45 & 0,33 & 0,18 & 0,00 & 0,86 & 1,82 \\
\hline 12. & Molètų r. SVB & 0,82 & 0,05 & 0,50 & 0,50 & 0,91 & 2,78 \\
\hline 13. & Palangos SVB & 0,86 & 0,38 & 0,55 & 0,45 & 0,00 & 2,24 \\
\hline 14. & Pakruojo r. SVB & 0,41 & 0,43 & 0,41 & 0,23 & 0,45 & 1,93 \\
\hline 15. & Pasvalio r. SVB & 0,91 & 0,90 & 0,82 & 0,64 & 0,68 & 3,95 \\
\hline 16. & Prienų r. SVB & 0,18 & 0,76 & 0,27 & 0,95 & 0,50 & 2,66 \\
\hline 17. & Skuodo r. SVB & 0,59 & n.d. & 0,59 & 0,14 & 0,77 & 2,09 \\
\hline 18. & Šilalès r. SVB & 0,32 & 1,00 & 0,14 & 0,27 & 0,32 & 2,05 \\
\hline 19. & Širvintų r. SVB & 0,68 & 0,52 & 0,45 & 0,36 & 1,00 & 3,01 \\
\hline 20. & Švenčionių r. SVB & 0,09 & 0,57 & 0,32 & 0,59 & 0,23 & 1,80 \\
\hline 21. & Varénos r. SVB & 0,73 & 0,95 & 0,68 & 0,91 & 0,59 & 3,86 \\
\hline
\end{tabular}




\begin{tabular}{|c|c|c|c|c|c|c|c|}
\hline \multirow[b]{2}{*}{$\begin{array}{l}\text { Eil } \\
\mathrm{Nr} .\end{array}$} & \multirow[b]{2}{*}{ SVB pavadinimas } & \multicolumn{5}{|c|}{ Procentilis } & \multirow{2}{*}{$\begin{array}{l}\text { Bendra } \\
\text { procenti- } \\
\text { lių suma }\end{array}$} \\
\hline & & $\begin{array}{l}1 \text { ro- } \\
\text { diklis }\end{array}$ & $\begin{array}{l}2 \text { ro- } \\
\text { diklis }\end{array}$ & $\begin{array}{l}3 \text { ro- } \\
\text { diklis }\end{array}$ & $\begin{array}{l}4 \text { ro- } \\
\text { diklis }\end{array}$ & $\begin{array}{l}5 \text { ro- } \\
\text { diklis }\end{array}$ & \\
\hline 22. & Visagino SVB & 0,00 & 0,00 & 0,00 & 0,09 & 0,00 & 0,09 \\
\hline 23. & Zarasų r. SVB & 0,77 & 0,81 & 0,91 & 0,55 & 0,82 & 3,86 \\
\hline
\end{tabular}

1 rodiklis - apsilankymu (fiziniu) skaičius 1 gyventojui;

2 rodiklis - virtualiu apsilankymu skaičius 1 gyventojui;

3 rodiklis - dokumentu išduočiu (fiz. vnt.) skaičius 1 gyventojui;

4 rodiklis - fondo apyvarta;

5 rodiklis - bendras bibliotekos darbo valandu, kai biblioteka atvira vartotojui, skaičius per metus, tenkantis 1000 gyventoju.

27 lentelè. II dimensija. 2 grupès biblioteku bendrasis naudojimosi biblioteka rodikliu verčiu procentilis

\begin{tabular}{|c|c|c|c|c|}
\hline $\begin{array}{l}\text { Eil. } \\
\text { Nr. }\end{array}$ & SVB pavadinimas & $\begin{array}{l}\text { Procentilių } \\
\text { suma }\end{array}$ & $\begin{array}{c}\text { Procentilių suma, } \\
\text { padalyta iš } 5\end{array}$ & $\begin{array}{l}\text { Galutinis } \\
\text { procentilis }\end{array}$ \\
\hline 1. & Visagino SVB & 0,09 & 0,018 & 0,00 \\
\hline 2. & Akmenès r. SVB & 0,52 & 0,104 & 0,05 \\
\hline 3. & Druskininkų SVB & 1,21 & 0,234 & 0,09 \\
\hline 4. & Švenčionių r. SVB & 1,80 & 0,360 & 0,14 \\
\hline 5. & Lazdijų r. SVB & 1,82 & 0,364 & 0,18 \\
\hline 6. & Pakruojo r. SVB & 1,93 & 0,386 & 0,23 \\
\hline 7. & Biržų r. SVB & 2,03 & 0,406 & 0,27 \\
\hline 8. & Šilalès r. SVB & 2,05 & 0,410 & 0,32 \\
\hline 9. & Palangos SVB & 2,24 & 0,466 & 0,36 \\
\hline 10. & Jurbarko r. SVB & 2,41 & 0,482 & 0,41 \\
\hline 11. & Elektrènų SVB & 2,46 & 0,492 & 0,45 \\
\hline 12. & Skuodo r. SVB* & 2,09 & 0,523 & 0,50 \\
\hline 13. & Prienų r. SVB & 2,66 & 0,532 & 0,55 \\
\hline 14. & Kupiškio r. SVB & 2,71 & 0,542 & 0,59 \\
\hline 15. & Molètų r. SVB & 2,78 & 0,556 & 0,64 \\
\hline 16. & Joniškio r. SVB & 2,93 & 0,586 & 0,68 \\
\hline 17. & Širvintų r. SVB & 3,01 & 0,602 & 0,73 \\
\hline 18. & Anykščių r. SVB & 3,13 & 0,626 & 0,77 \\
\hline 19. & Ignalinos r. SVB & 3,50 & 0,700 & 0,82 \\
\hline 20. & Varènos r. SVB & 3,86 & 0,772 & 0,86 \\
\hline 21. & Zarasų r. SVB & 3,86 & 0,772 & 0,86 \\
\hline 22. & Alytaus r. SVB & 3,91 & 0,782 & 0,95 \\
\hline 23. & Pasvalio r. SVB & 3,95 & 0,790 & 1,00 \\
\hline
\end{tabular}

* Skuodo rajono SVB procentiliu suma padalyta iš 4, nes 2 rodikliui (virtualių apsilankymų skaičius 1 gyventojui) apskaičiuoti nera duomenu (n. d.). 
28 lentelè. II dimensija. 2 grupés biblioteku naudojimosi biblioteka rodiklio ivertinimas

\begin{tabular}{|c|c|c|c|c|}
\hline $\begin{array}{l}\text { Eil. } \\
\text { Nr. }\end{array}$ & SVB pavadinimas & Procentilių suma & $\begin{array}{c}\text { Procentilių suma, } \\
\text { padalyta iš } 5\end{array}$ & $\begin{array}{l}\text { Galutinis } \\
\text { procentilis }\end{array}$ \\
\hline 1. & Pasvalio r. SVB & 3,95 & 0,790 & 1,00 \\
\hline 2. & Alytaus r. SVB & 3,91 & 0,782 & 0,95 \\
\hline 3. & Zarasų r. SVB & 3,86 & 0,772 & 0,86 \\
\hline 4. & Varénos r. SVB & 3,86 & 0,772 & 0,86 \\
\hline 5. & Ignalinos r. SVB & 3,50 & 0,700 & 0,82 \\
\hline 6. & Anykščių r. SVB & 3,13 & 0,626 & 0,77 \\
\hline 7. & Širvintų r. SVB & 3,01 & 0,602 & 0,73 \\
\hline 8. & Joniškio r. SVB & 2,93 & 0,586 & 0,68 \\
\hline 9. & Molètų r. SVB & 2,78 & 0,556 & 0,64 \\
\hline 10. & Kupiškio r. SVB & 2,71 & 0,542 & 0,59 \\
\hline 11. & Prienų r. SVB & 2,66 & 0,532 & 0,55 \\
\hline 12. & Skuodo r. SVB* & 2,09 & 0,523 & 0,50 \\
\hline 13. & Elektrènų SVB & 2,46 & 0,492 & 0,45 \\
\hline 14. & Jurbarko r. SVB & 2,41 & 0,482 & 0,41 \\
\hline 15. & Palangos SVB & 2,24 & 0,466 & 0,36 \\
\hline 16. & Šilalès r. SVB & 2,05 & 0,410 & 0,32 \\
\hline 17. & Biržų r. SVB & 2,03 & 0,406 & 0,27 \\
\hline 18. & Pakruojo r. SVB & 1,93 & 0,386 & 0,23 \\
\hline 19. & Lazdijų r. SVB & 1,82 & 0,364 & 0,18 \\
\hline 20. & Švenčionių r. SVB & 1,80 & 0,360 & 0,14 \\
\hline 21. & Druskininkų SVB & 1,21 & 0,234 & 0,09 \\
\hline 22. & Akmenès r. SVB & 0,52 & 0,104 & 0,05 \\
\hline 23. & Visagino SVB & 0,09 & 0,018 & 0,00 \\
\hline
\end{tabular}

3 grupè. I aukščiausią grupę pateko ir po žvaigždę pelnė Rokiškio, Utenos, Panevėžio, Ukmergès, Radviliškio, Jonavos ir Šilutės rajonų SVB (žr. 31 lentelę). Rokiškio rajono SVB pagal II dimensijos du rodiklius apsilankymu (fziniu) skaičiu 1 gyventojui ir dokumentu išduočiu skaičiu 1 gyventojui ịvertinta aukščiausiai (procentiliai - 1,00), o pagal rodikliu fondo apyvarta ir bendras bibliotekos darbo valandu, kai biblioteka atvira vartotojui, skaičius per metus, tenkantis 1000 gyventoju vertes - 0,94 procentilio. 
Utenos rajono rajono SVB šios dimensijos rodikliu procentiliai - nuo 0,39 iki 0,94. Panevėžio ir Ukmergès rajonų SVB surinko vienodą procentilių sumą, bet šios grupès biblioteku reitinge Panevėžio biblioteka yra aukščiau, nes jos rodiklio bendras bibliotekos darbo valandu, kai biblioteka atvira vartotojui, skaičius per metus, tenkantis 1000 gyventoju vertès procentilis yra 0,89, o Ukmergès - 0,78 (žr. 30, 31 lenteles).

4 SVB - Rokiškio, Utenos, Panevėžio ir Radviliškio rajonų - ir I dimensijoje buvo patekusios ị auksinę grupę bei pelniusios po žvaigždę. Vis dèlto naudojimąsi bibliotekos paslaugomis gali lemti ne tik turimi ištekliai, infrastruktūra, bet ir kiti veiksniai. Pavyzdžiui, Jonavos rajono SVB, kuri pagal išteklius ir infrastruktūrą gavo žemiausią ịvertinimą (procentilis 0,00), II dimensijoje pateko ị aukščiausią grupę. Šis pavyzdys rodo, kad II dimensijos rodiklių vertés priklauso nuo daugelio veiksnių, kuriems nustatyti ir ịvertinti reikètų papildomų duomenų ir nuodugnesnès analizès (žr. 16, 31 lenteles).

I vidurinę (šviesiai mèlyna) grupę pateko ir po pusę žvaigždès gavo Kelmès, Traku, Telšių, Šakių, Šalčininku, Kaišiadorių rajonų SVB.

Žemiausioje grupeje liko 6 SVB: Kretingos, Plungès, Raseiniu, Vilkaviškio, Šiaulių ir Tauragès rajonų. Remiantis BIX metodika, Šiaulių rajono SVB naudojimasis biblioteka įvertintas žemais procentiliais. Šis ivvertinimas yra proporcingas I dimensijos (Ištekliai ir infrastruktūra) rezultatams, nes ši SVB ir šiuo požiūriu yra žemiausioje grupejje, jos galutinis procentilis nesiekè 0,32 (žr. 16, 31 lenteles).

29 lentelè. II dimensija. 3 grupes biblioteku naudojimosi biblioteka rodikliu verčiu procentiliais suma

\begin{tabular}{|l|l|c|c|c|c|c|c|}
\multirow{2}{*}{$\begin{array}{c}\text { Eil } \\
\text { Nr. }\end{array}$} & \multicolumn{1}{|c|}{ SVB pavadinimas } & $\begin{array}{c}\text { Procentilis } \\
\text { 1 ro- } \\
\text { diklis }\end{array}$ & $\begin{array}{c}\text { 2 ro- } \\
\text { diklis }\end{array}$ & $\begin{array}{c}\text { 3 ro- } \\
\text { diklis }\end{array}$ & $\begin{array}{c}\text { 4 ro- } \\
\text { diklis }\end{array}$ & $\begin{array}{c}\text { 5 ro-- } \\
\text { diklis }\end{array}$ & $\begin{array}{c}\text { Bendra } \\
\text { procenti- } \\
\text { lių suma }\end{array}$ \\
\hline 1. & Jonavos r. SVB & 0,39 & 0,67 & 0,89 & 1,00 & 0,00 & 2,95 \\
\hline 2. & Kaišiadorių r. SVB & 0,72 & 0,44 & 0,22 & 0,17 & 0,50 & 2,05 \\
\hline 3. & Kelmés r. SVB & 0,56 & 0,61 & 0,50 & 0,39 & 0,61 & 2,67 \\
\hline
\end{tabular}




\begin{tabular}{|c|c|c|c|c|c|c|c|}
\hline \multirow[b]{2}{*}{$\begin{array}{l}\text { Eil } \\
\text { Nr. }\end{array}$} & \multirow[b]{2}{*}{ SVB pavadinimas } & \multicolumn{5}{|c|}{ Procentilis } & \multirow{2}{*}{$\begin{array}{l}\text { Bendra } \\
\text { procenti- } \\
\text { lių suma }\end{array}$} \\
\hline & & $\begin{array}{l}1 \text { ro- } \\
\text { diklis }\end{array}$ & $\begin{array}{l}2 \text { ro- } \\
\text { diklis }\end{array}$ & $\begin{array}{l}3 \text { ro- } \\
\text { diklis }\end{array}$ & $\begin{array}{l}4 \text { ro- } \\
\text { diklis }\end{array}$ & $\begin{array}{l}5 \text { ro- } \\
\text { diklis }\end{array}$ & \\
\hline 4. & Kretingos r. SVB & 0,17 & 0,78 & 0,39 & 0,61 & 0,06 & 2,01 \\
\hline 5. & Panevėžio r. SVB & 0,67 & 1,00 & 0,67 & 0,44 & 0,89 & 3,67 \\
\hline 6. & Plungės r. SVB & 0,44 & 0,22 & 0,11 & 0,67 & 0,28 & 1,72 \\
\hline 7. & Radviliškio r. SVB & 0,89 & 0,50 & 0,72 & 0,50 & 1,00 & 3,61 \\
\hline 8. & Raseinių r. SVB & 0,33 & 0,39 & 0,28 & 0,22 & 0,44 & 1,66 \\
\hline 9. & Rokiškio r. SVB & 1,00 & 0,56 & 1,00 & 0,94 & 0,94 & 4,44 \\
\hline 10. & Šakių r. SVB & 0,22 & 0,28 & 0,44 & 0,56 & 0,72 & 2,22 \\
\hline 11. & Šalčininkų r. SVB & 0,28 & 0,06 & 0,61 & 0,28 & 0,83 & 2,06 \\
\hline 12. & Šiaulių r. SVB & 0,00 & 0,72 & 0,00 & 0,00 & 0,22 & 0,94 \\
\hline 13. & Šilutès r. SVB & 0,83 & 0,11 & 0,83 & 0,89 & 0,17 & 2,83 \\
\hline 14. & Tauragès r. SVB & 0,06 & 0,00 & 0,06 & 0,06 & 0,67 & 0,85 \\
\hline 15. & Telšių r. SVB & 0,61 & 0,89 & 0,33 & 0,33 & 0,33 & 2,49 \\
\hline 16. & Trakų r. SVB & 0,50 & 0,33 & 0,78 & 0,78 & 0,11 & 2,50 \\
\hline 17. & Ukmergès r. SVB & 0,78 & 0,83 & 0,56 & 0,72 & 0,78 & 3,67 \\
\hline 18. & Utenos r. SVB & 0,94 & 0,94 & 0,94 & 0,83 & 0,39 & 4,04 \\
\hline 19. & Vilkaviškio r. SVB & 0,11 & 0,17 & 0,17 & 0,11 & 0,56 & 1,12 \\
\hline
\end{tabular}

1 rodiklis - apsilankymu (fiziniu) skaičius 1 gyventojui;

2 rodiklis - virtualiu apsilankymu skaičius 1 gyventojui;

3 rodiklis - dokumentu išduočiu (fiz. vnt.) skaičius 1 gyventojui;

4 rodiklis - fondo apyvarta;

5 rodiklis - bendras bibliotekos darbo valandu, kai biblioteka atvira vartotojui, skaičius per metus, tenkantis 1000 gyventoju.

30 lentelè. II dimensija. 3 grupés biblioteku bendrasis naudojimosi biblioteka rodikliu verčiu procentilis

\begin{tabular}{|c|l|c|c|c|}
\hline $\begin{array}{c}\text { Ei1. } \\
\text { Nr. }\end{array}$ & \multicolumn{1}{|c|}{ SVB pavadinimas } & $\begin{array}{c}\text { Procentilių } \\
\text { suma }\end{array}$ & $\begin{array}{c}\text { Procentilių suma, } \\
\text { padalyta iš 5 }\end{array}$ & $\begin{array}{c}\text { Galutinis } \\
\text { procentilis }\end{array}$ \\
\hline 1. & Tauragès r. SVB & 0,85 & 0,170 & 0,00 \\
\hline 2. & Šiaulių r. SVB & 0,94 & 0,188 & 0,06 \\
\hline 3. & Vilkaviškio r. SVB & 1,12 & 0,224 & 0,11 \\
\hline 4. & Raseinių r. SVB & 1,66 & 0,332 & 0,17 \\
\hline 5. & Plungės r. SVB & 1,72 & 0,344 & 0,22 \\
\hline 6. & Kretingos r. SVB & 2,01 & 0,402 & 0,28 \\
\hline 7. & Kaišiadorių r. SVB & 2,05 & 0,410 & 0,33 \\
\hline 8. & Šalčininkų r. SVB & 2,06 & 0,412 & 0,39 \\
\hline 9. & Šakių r. SVB & 2,22 & 0,444 & 0,44 \\
\hline
\end{tabular}




\begin{tabular}{|c|l|c|c|c|}
\hline $\begin{array}{c}\text { Eil. } \\
\text { Nr. }\end{array}$ & \multicolumn{1}{|c|}{ SVB pavadinimas } & $\begin{array}{c}\text { Procentilių } \\
\text { suma }\end{array}$ & $\begin{array}{c}\text { Procentilių suma, } \\
\text { padalyta ǐ 5 }\end{array}$ & $\begin{array}{c}\text { Galutinis } \\
\text { procentilis }\end{array}$ \\
\hline 10. & Telšių r. SVB & 2,49 & 0,498 & 0,50 \\
\hline 11. & Trakų r. SVB & 2,50 & 0,500 & 0,56 \\
\hline 12. & Kelmès r. SVB & 2,67 & 0,534 & 0,61 \\
\hline 13. & Šilutés r. SVB & 2,83 & 0,566 & 0,67 \\
\hline 14. & Jonavos r. SVB & 2,95 & 0,590 & 0,72 \\
\hline 15. & Radviliškio r. SVB & 3,61 & 0,722 & 0,78 \\
\hline 16. & Panevěžio r. SVB & 3,67 & 0,734 & 0,83 \\
\hline 17. & Ukmergès r. SVB & 3,67 & 0,734 & 0,83 \\
\hline 18. & Utenos r. SVB & 4,04 & 0,808 & 0,94 \\
\hline 19. & Rokiškio r. SVB & 4,44 & 0,888 & 1,00 \\
\hline
\end{tabular}

31 lentelè. II dimensija. 3 grupès biblioteku naudojimosi biblioteka įvertinimas

\begin{tabular}{|c|c|c|c|c|}
\hline $\begin{array}{l}\text { Eil. } \\
\text { Nr. }\end{array}$ & SVB pavadinimas & $\begin{array}{l}\text { Procentilių } \\
\text { suma }\end{array}$ & $\begin{array}{l}\text { Procentilių suma, } \\
\text { padalyta iš } 5\end{array}$ & $\begin{array}{l}\text { Galutinis } \\
\text { procentilis }\end{array}$ \\
\hline 1. & Rokiškio r. SVB & 4,44 & 0,888 & 1,00 \\
\hline 2. & Utenos r. SVB & 4,04 & 0,808 & 0,94 \\
\hline 3. & Panevėžio r. SVB & 3,67 & 0,734 & 0,83 \\
\hline 4. & Ukmergès r. SVB & 3,67 & 0,734 & 0,83 \\
\hline 5. & Radviliškio r. SVB & 3,61 & 0,722 & 0,78 \\
\hline 6. & Jonavos r. SVB & 2,95 & 0,590 & 0,72 \\
\hline 7. & Šilutès r. SVB & 2,83 & 0,566 & 0,67 \\
\hline 8. & Kelmès r. SVB & 2,67 & 0,534 & 0,61 \\
\hline 9. & Trakų r. SVB & 2,50 & 0,500 & 0,56 \\
\hline 10. & Telšių r. SVB & 2,49 & 0,498 & 0,50 \\
\hline 11. & Šakių r. SVB & 2,22 & 0,444 & 0,44 \\
\hline 12. & Šalčininkų r. SVB & 2,06 & 0,412 & 0,39 \\
\hline 13. & Kaišiadorių r. SVB & 2,05 & 0,410 & 0,33 \\
\hline 14. & Kretingos r. SVB & 2,01 & 0,402 & 0,28 \\
\hline 15. & Plungès r. SVB & 1,72 & 0,344 & 0,22 \\
\hline 16. & Raseinių r. SVB & 1,66 & 0,332 & 0,17 \\
\hline 17. & Vilkaviškio r. SVB & 1,12 & 0,224 & 0,11 \\
\hline 18. & Šiaulių r. SVB & 0,94 & 0,188 & 0,06 \\
\hline 19. & Tauragès r. SVB & 0,85 & 0,170 & 0,00 \\
\hline
\end{tabular}


4 grupè. İ aukščiausią grupę pateko Kèdainių, Klaipèdos rajonų ir Marijampolès SVB (žr. 34 lentelę). Kèdainių rajono SVB atsidūrè aukščiausioje vietoje pagal rodiklių apsilankymu (fiziniu) skaičius 1 gyventojui; dokumentu išduočiu (fiz. vnt.) skaičius 1 gyventojui procentilius $(1,00)$, o kiti rodikliu procentiliai svyruoja nuo 0,57 (fondo apyvarta) iki 0,86 (bendras bibliotekos darbo valandu, kai biblioteka atvira vartotojui, skaičius per metus, tenkantis 1000 gyventoju). Klaipèdos rajono SVB rodiklių verčiu procentiliai varijuoja nuo 0,43 iki 1,00 (žr. 32 lentelę).

I vidurinę grupę pateko ir pusę žvaigždès pelnè Panevezžio miesto ir Kauno rajono SVB.

Žemiausioje grupeje liko 3 SVB: Alytaus miesto, Mažeikių ir Vilniaus rajonų. Remiantis BIX metodika, šių SVB naudojimasis biblioteka įvertintas žemiausiais procentiliais. Be to, Alytaus $\mathrm{m}$. ir Vilniaus $\mathrm{r}$. SVB II dimensijos ịvertinimas yra proporcingas I dimensijos (Ištekliai ir infrastruktūra) rezultatams, nes I dimensijoje jos yra žemiausioje grupëje, jų bendrasis procentilis nesiekè 0,32 (žr. 19, 34 lenteles).

32 lentelè. II dimensija. 4 grupès biblioteku naudojimosi biblioteka rodikliu verčiu procentiliais suma

\begin{tabular}{|c|c|c|c|c|c|c|c|}
\hline \multirow[b]{2}{*}{$\begin{array}{l}\text { Eil } \\
\text { Nr. }\end{array}$} & \multirow[b]{2}{*}{ SVB pavadinimas } & \multicolumn{5}{|c|}{ Procentilis } & \multirow{2}{*}{$\begin{array}{l}\text { Bendra } \\
\text { procenti- } \\
\text { lių suma }\end{array}$} \\
\hline & & $\begin{array}{l}1 \text { ro- } \\
\text { diklis }\end{array}$ & $\begin{array}{l}2 \text { ro- } \\
\text { diklis }\end{array}$ & $\begin{array}{l}3 \text { ro- } \\
\text { diklis }\end{array}$ & $\begin{array}{l}4 \text { ro- } \\
\text { diklis }\end{array}$ & $\begin{array}{l}5 \text { ro- } \\
\text { diklis }\end{array}$ & \\
\hline 1. & Alytaus m. SVB & 0,29 & 0,33 & 0,57 & 0,86 & 0,00 & 2,05 \\
\hline 2. & Kauno r. SVB & 0,57 & 1,00 & 0,14 & 0,14 & 0,29 & 2,14 \\
\hline 3. & Kèdainių r. SVB & 1,00 & 0,83 & 1,00 & 0,57 & 0,86 & 4,26 \\
\hline 4. & Klaipèdos r. SVB & 0,86 & n.d. & 0,86 & 0,43 & 1,00 & 3,15 \\
\hline 5. & Marijampolès SVB & 0,71 & 0,50 & 0,71 & 0,71 & 0,43 & 3,06 \\
\hline 6. & Mažeikių r. SVB & 0,43 & 0,17 & 0,43 & 0,29 & 0,71 & 2,03 \\
\hline 7. & Panevėžio m. SVB & 0,14 & 0,67 & 0,29 & 1,00 & 0,14 & 2,24 \\
\hline 8. & Vilniaus r. SVB & 0,00 & 0,00 & 0,00 & 0,00 & 0,57 & 0,57 \\
\hline
\end{tabular}

1 rodiklis - apsilankymu (fiziniu) skaičius 1 gyventojui;

2 rodiklis - virtualiu apsilankymu skaičius 1 gyventojui;

3 rodiklis - dokumentu išduočiu (fiz. vnt.) skaičius 1 gyventojui;

4 rodiklis - fondo apyvarta;

5 rodiklis - bendras bibliotekos darbo valandu, kai biblioteka atvira vartotojui, skaičius per metus, tenkantis 1000 gyventoju. 
33 lentelè. II dimensija. 4 grupès biblioteku bendrasis naudojimosi biblioteka rodikliu verčiu procentilis

\begin{tabular}{|c|l|c|c|c|}
\hline $\begin{array}{c}\text { Eil. } \\
\text { Nr. }\end{array}$ & \multicolumn{1}{|c|}{ SVB pavadinimas } & Procentilių suma & $\begin{array}{c}\text { Procentilių suma, } \\
\text { padalyta iš 5 }\end{array}$ & $\begin{array}{c}\text { Galutinis pro- } \\
\text { centilis }\end{array}$ \\
\hline 1. & Vilniaus r. SVB & 0,57 & 0,114 & 0,00 \\
\hline 2. & Mažeikių r. SVB & 2,03 & 0,406 & 0,14 \\
\hline 3. & Alytaus m. SVB & 2,05 & 0,410 & 0,29 \\
\hline 4. & Kauno r. SVB & 2,14 & 0,428 & 0,43 \\
\hline 5. & Panevežio m. SVB & 2,24 & 0,448 & 0,57 \\
\hline 6. & Marijampolès SVB & 3,06 & 0,612 & 0,71 \\
\hline 7. & Klaipédos r. SVB* & 3,15 & 0,788 & 0,86 \\
\hline 8. & Kèdainių r. SVB & 4,26 & 0,852 & 1,00 \\
\hline
\end{tabular}

* Klaipedos rajono SVB procentiliu suma padalyta iš 4, nes 2 rodikliui (virtualių apsilankymų skaičius 1 gyventojui) apskaičiuoti nera duomenu.

34 lentelè. II dimensija. 4 grupès biblioteku naudojimosi biblioteka įvertinimas

\begin{tabular}{|c|c|c|c|c|}
\hline $\begin{array}{l}\text { Eil. } \\
\text { Nr. }\end{array}$ & SVB pavadinimas & Procentilių suma & $\begin{array}{c}\text { Procentilių suma, } \\
\text { padalyta iš } 5\end{array}$ & $\begin{array}{l}\text { Galutinis } \\
\text { procentilis }\end{array}$ \\
\hline 1. & Kèdainių r. SVB & 4,26 & 0,852 & 1,00 \\
\hline 2. & Klaipedos r. SVB & 3,15 & 0,788 & 0,86 \\
\hline 3. & Marijampolès SVB & 3,06 & 0,612 & 0,71 \\
\hline 4. & Panevėžio m. SVB & 2,24 & 0,448 & 0,57 \\
\hline 5. & Kauno r. SVB & 2,14 & 0,428 & 0,43 \\
\hline 6. & Alytaus m. SVB & 2,05 & 0,410 & 0,29 \\
\hline 7. & Mažeikių r. SVB & 2,03 & 0,406 & 0,14 \\
\hline 8. & Vilniaus r. SVB & 0,57 & 0,114 & 0,00 \\
\hline
\end{tabular}

5 grupè. İ aukščiausiąją grupę pateko ir po žvaigždę gavo Klaipèdos ir Kauno miestų SVB (žr. 37 lentelę).

Klaipedos miesto SVB aukščiausiose pozicijose yra pagal 3 rodiklių: apsilankymu (fiziniu) skaičius 1 gyventojui; virtualiu apsilankymu skaičius 1 gyventojui; dokumentu išduočiu (fiz. vnt.) skaičius 1 gyventojui - verčiu procentilius $(1,00)$, o kitų rodiklių procentiliai - 0,67 (35 lentelè).

I vidurinę grupę pateko ir pusę žvaigždès igijo Šiaulių miesto SVB. 
Remiantis BIX metodika, Vilniaus miesto SVB naudojimasis biblioteka vertinamas žemiausiai. Šis įvertinimas yra proporcingas I dimensijos (Ištekliai ir infrastruktūra) rezultatams, šiuo požiūriu Vilniaus biblioteka irgi įvertinta žemiausiu procentiliu $(0,00)$ (žr. 22, 37 lenteles).

Palyginus 2013 ir 2014 m. tyrimus, išryškëjo tokie rezultatai: abu kartus pagal II dimensijos rezultatus Klaipèdos m. SVB buvo auksinëje grupeje ir pelnè žvaigždę; Kauno m. SVB 2013 m. tyrime buvo žemiausioje grupèje, o $2014 \mathrm{~m}$. pagerino savo pozicijas ir pateko ị auksinę grupę. Vilniaus m. SVB $2013 \mathrm{~m}$. tyrime nedalyvavo.

35 lentelè. II dimensija. 5 grupes biblioteku naudojimosi biblioteka rodikliu verčiu procentiliais suma

\begin{tabular}{|c|c|c|c|c|c|c|c|}
\hline \multirow[b]{2}{*}{$\begin{array}{l}\text { Eil } \\
\text { Nr. }\end{array}$} & \multirow[b]{2}{*}{ SVB pavadinimas } & \multicolumn{5}{|c|}{ Procentilis } & \multirow{2}{*}{$\begin{array}{l}\text { Bendra } \\
\text { procenti- } \\
\text { lių suma }\end{array}$} \\
\hline & & $\begin{array}{l}1 \text { ro- } \\
\text { diklis }\end{array}$ & $\begin{array}{l}2 \text { ro- } \\
\text { diklis }\end{array}$ & $\begin{array}{l}3 \text { ro- } \\
\text { diklis }\end{array}$ & $\begin{array}{l}4 \text { ro- } \\
\text { diklis }\end{array}$ & $\begin{array}{l}5 \text { ro- } \\
\text { diklis }\end{array}$ & \\
\hline 1. & Kauno m. SVB & 0,67 & 0,33 & 0,33 & 0,33 & 1,00 & 2,66 \\
\hline 2. & Klaipèdos m. SVB & 1,00 & 1,00 & 1,00 & 0,67 & 0,67 & 4,34 \\
\hline 3. & Šiaulių m. SVB & 0,33 & 0,67 & 0,67 & 0,00 & 0,33 & 2,00 \\
\hline 4. & Vilniaus m. SVB & 0,00 & 0,00 & 0,00 & 1,00 & 0,00 & 1,00 \\
\hline
\end{tabular}

1 rodiklis - apsilankymu (fziniu) skaičius 1 gyventojui;

2 rodiklis - virtualiu apsilankymu skaičius 1 gyventojui;

3 rodiklis - dokumentu išduočiu (fiz. vnt.) skaičius 1 gyventojui;

4 rodiklis - fondo apyvarta;

5 rodiklis - bendras bibliotekos darbo valandu, kai biblioteka atvira vartotojui, skaičius per metus, tenkantis 1000 gyventoju.

36 lentelè. II dimensija. 5 grupes biblioteku bendrasis naudojimosi biblioteka rodikliu verčiu procentilis

\begin{tabular}{|c|l|c|c|c|}
\hline Eil. & \multicolumn{1}{|c|}{ SVB pavadinimas } & $\begin{array}{c}\text { Procentilių } \\
\text { suma }\end{array}$ & $\begin{array}{c}\text { Procentilių suma, } \\
\text { padalyta iš 5 }\end{array}$ & $\begin{array}{c}\text { Galutinis } \\
\text { procentillis }\end{array}$ \\
\hline 1. & Vilniaus m. SVB & 1,00 & 0,200 & 0,00 \\
\hline 2. & Šiaulių m. SVB & 2,00 & 0,400 & 0,33 \\
\hline 3. & Kauno m. SVB & 2,66 & 0,532 & 0,67 \\
\hline 4. & Klaipédos m. SVB & 4,34 & 0,868 & 1,00 \\
\hline
\end{tabular}


37 lentelè. II dimensija. 5 grupès biblioteku naudojimosi biblioteka įvertinimas

\begin{tabular}{|c|c|c|c|c|}
\hline $\begin{array}{l}\text { Eil. } \\
\text { Nr. }\end{array}$ & SVB pavadinimas & $\begin{array}{l}\text { Procentilių } \\
\text { suma }\end{array}$ & $\begin{array}{c}\text { Procentilių suma, } \\
\text { padalyta iš } 5\end{array}$ & $\begin{array}{l}\text { Galutinis } \\
\text { procentilis }\end{array}$ \\
\hline 1. & Klaipèdos m. SVB & 4,34 & 0,868 & 1,00 \\
\hline 2. & Kauno m. SVB & 2,66 & 0,532 & 0,67 \\
\hline 3. & Šiaulių m. SVB & 2,00 & 0,400 & 0,33 \\
\hline 4. & Vilniaus m. SVB & 1,00 & 0,200 & 0,00 \\
\hline
\end{tabular}

\section{III dimensija. Našumas}

Šioje dimensijoje vertinami 4 rodikliai, kurie parodo lěšų ir darbo laiko sąnaudas, reikalingas siekiant užtikrinti pagrindines bibliotekos paslaugas. Trys šios dimensijos rodikliai vertinami atvirkštine seka, t. y. kuo mažesnè rodiklio vertè, tuo aukštesnis įvertinimas arba kuo mažesnèmis sąnaudomis užtikrinama bibliotekos veikla, tuo geriau vertinama biblioteka. Pateikiami šios dimensijos bibliotekų 1, 2, 3, 4, 5 grupių rezultatai bei ju reitingai.

1 grupè. Čia ị aukščiausią grupę pateko ir po žvaigždę gavo Pagėgiu, Birštono SVB (žr. 40 lentelę).

Atkreiptinas dėmesys, kad Birštono SVB rezultatai, vertinant tiek I dimensijos (Ištekliai ir infrastruktūra), tiek II dimensijos (Naudojimasis biblioteka) požiūriu, yra tolygūs: ji pateko į aukščiausią̧ą grupę ir pelnė po žvaigždę, o III dimensijos rezultatas tik patvirtina šios bibliotekos pranašumą tarp kitų grupès bibliotekų. Teikiamos bibliotekos paslaugos ir tinkamas ju prieigos organizavimas rodo bibliotekos gebëjimą veiksmingai paskirstyti darbo sąnaudas, panaudoti turimus išteklius. Paslaugų ir naudojimosi jomis sąnaudų santykis įvertintas aukščiausiai (žr. 10, 25, 40 lenteles).

Pagėgių SVB rezultatai yra geri: I ir III dimensijose pateko į auksinę grupę ir pelnè po žvaigždę; II dimensijoje - ị vidurinę grupę ir pelnė pusę žvaigždès.

Neringos SVB pagal I ir II dimensiju rodiklius pateko ị vidurinę grupę ir gavo po pusę žvaigždès, o III dimensijoje atsidūrẻ žemiausioje grupèje. 
Kalvarijos SVB su I dimensijos rodikliais pateko ị vidurinę grupę ir pelnè pusę žvaigždès, o pagal II ir III dimensijų rodiklius atsidūrè tarp blogiausių (procentilis - 0,20). Bibliotekų veiklos našumą parodantys rodikliai tiesiogiai susiję su aptarnaujamos bendruomenès naudojimusi bibliotekos paslaugomis, todèl aukščiausius įvertinimus gavo tos SVB, kurių paslaugomis gyventojai naudojasi intensyviausiai. Pritaikius BIX metodiką, Neringos $(0,00)$ ir Kalvarijos SVB $(0,20)$ paslaugu ir naudojimusi jomis santykis įvertintas žemiausiai (žr. 10, 25, 40 lenteles).

38 lentelè. III dimensija. 1 grupè bibliotekų našumo rodikliu verčiu procentiliais suma

\begin{tabular}{|c|l|c|c|c|c|c|}
\hline \multirow{2}{*}{$\begin{array}{c}\text { Eil } \\
\text { Nr. }\end{array}$} & \multirow{2}{*}{ SVB pavadinimas } & \multicolumn{4}{|c|}{ Procentilis } & Bendra pro- \\
\cline { 3 - 7 } & & 1 rodiklis & 2 rodiklis & 3 rodiklis & 4 rodiklis & centilių suma \\
\hline 1. & Birštono SVB & 0,20 & 0,20 & 1,00 & 1,00 & 2,40 \\
\hline 2. & Kalvarijos SVB & 0,80 & 0,40 & 0,20 & 0,00 & 1,40 \\
\hline 3. & Kazlų Rūdos SVB & 0,60 & 0,60 & 0,40 & 0,40 & 2,00 \\
\hline 4. & Neringos SVB & 0,00 & 0,00 & 0,60 & 0,20 & 0,80 \\
\hline 5. & Pagègių SVB & 1,00 & 1,00 & 0,80 & 0,80 & 3,60 \\
\hline 6. & Rietavo SVB & 0,40 & 0,80 & 0,00 & 0,60 & 1,80 \\
\hline
\end{tabular}

1 rodiklis - fondui komplektuoti skirtos lësos, tenkančios 1 išduočiai;

2 rodiklis - darbuotoju darbo valandu ir valandu, per kurias biblioteka atvira lankytojams, santykis;

3 rodiklis - apsilankymu skaičius per 1 bibliotekos darbo (kai ji atvira lankytojui) valanda;

4 rodiklis - paprastosios 1 apsilankymui skirtos išlaidos.

39 lentelè. III dimensija. 1 grupès bibliotekų bendrasis našumo rodikliu verčiu procentilis

\begin{tabular}{|c|l|c|c|c|}
\hline $\begin{array}{c}\text { Eil. } \\
\text { Nr. }\end{array}$ & \multicolumn{1}{|c|}{ SVB pavadinimas } & $\begin{array}{c}\text { Procentilių } \\
\text { suma }\end{array}$ & $\begin{array}{c}\text { Procentilių suma, } \\
\text { padalyta iš 4 }\end{array}$ & $\begin{array}{c}\text { Galutinis } \\
\text { procentilis }\end{array}$ \\
\hline 1. & Neringos SVB & 0,80 & 0,200 & 0,00 \\
\hline 2. & Kalvarijos SVB & 1,40 & 0,350 & 0,20 \\
\hline 3. & Rietavo SVB & 1,80 & 0,450 & 0,40 \\
\hline 4. & Kazlų Rūdos SVB & 2,00 & 0,500 & 0,60 \\
\hline 5. & Birštono SVB & 2,40 & 0,600 & 0,80 \\
\hline 6. & Pagègių SVB & 3,60 & 0,900 & 1,00 \\
\hline
\end{tabular}


40 lentelè. III dimensija. 1 grupès bibliotekų našumo įvertinimas

\begin{tabular}{|c|c|c|c|c|}
\hline $\begin{array}{l}\text { Eil. } \\
\text { Nr. }\end{array}$ & SVB pavadinimas & $\begin{array}{l}\text { Procentilių } \\
\text { suma }\end{array}$ & $\begin{array}{c}\text { Procentilių suma, } \\
\text { padalyta iš } 4\end{array}$ & $\begin{array}{l}\text { Galutinis pro- } \\
\text { centilis }\end{array}$ \\
\hline 1. & Pagėgių SVB & 3,60 & 0,900 & 1,00 \\
\hline 2. & Birštono SVB & 2,40 & 0,600 & 0,80 \\
\hline 3. & Kazlų Rūdos SVB & 2,00 & 0,500 & 0,60 \\
\hline 4. & Rietavo SVB & 1,80 & 0,450 & 0,40 \\
\hline 5. & Kalvarijos SVB & 1,40 & 0,350 & 0,20 \\
\hline 6. & Neringos SVB & 0,80 & 0,200 & 0,00 \\
\hline
\end{tabular}

2 grupè. İ aukščiausiąją grupę pateko ir po žvaigždę pelnẻ Alytaus, Pasvalio, Varènos, Joniškio, Ignalinos, Jurbarko, Švenčionių rajonų ir Druskininkų SVB (žr. 43 lentelę).

Pasvalio ir Ignalinos rajonų SVB rezultatai pagal pagrindinius veiklos rodiklius yra tolygūs, abi SVB pateko ị aukščiausią grupę: Pasvalio r. SVB I dimensijos rodikliu galutinis procentilis - 0,68, Ignalinos r. SVB - 0,77; II dimensijos Pasvalio r. SVB galutinis procentilis - 1,00, o Ignalinos rajono SVB - 0,82. III dimensijos rezultatai tik patvirtina šiu SVB gebèjimą našiai teikti veiksmingas paslaugas, organizuoti tinkamą jų prieigą, racionaliai paskirstyti darbo sąnaudas ir panaudoti turimus išteklius (žr. 13, 28, 43 lenteles).

Geru rezultatu pasiekè Alytaus rajono SVB: pagal II ir III dimensiju rezultatus pateko i̇ aukščiausią grupę, o I dimensijos - liko per vidurị.

Druskininkų SVB su I ir II dimensijų rodikliais atsidūrè žemiausioje grupèje, o III dimensijos - pateko ị auksinę grupę ir pelnẻ žvaigždę. Tokị rezultatą daugiausia nulèmé sumažèjusios paprastosios 1 apsilankymui skirtos lèšos (2013 m. atlikto tyrimo duomenimis, paprastujų išlaidų suma Druskininkų SVB buvo 63 proc. didesné; tiketina, kad dèl bibliotekos ịsikūrimo naujame pastate) (žr. 13, 28, 41, 43 lenteles). 
Pagal III dimensijos rodiklius ị vidurinę grupę pateko Palangos miesto, Molètų, Anykščių, Skuodo, Biržų, Pakruojo rajonų SVB ir pelnẻ po pusę žvaigždès.

Žemiausioje grupëje liko 9 SVB: Širvintų, Zarasų, Prienų, Šilalès, Lazdijų, Kupiškio, Akmenès rajonų ir Elektrènų bei Visagino SVB.

Akmenès rajono ir Visagino SVB rezultatai (išteklių ir infrastruktūros, naudojimosi biblioteka dimensijos) yra proporcingi III dimensijoje (Našumas) pasiektiems rezultatams: Akmenès r. SVB I dimensijos procentilis - 0,14, II dimensijos procentilis - 0,05. Visagino SVB stokoja materialiųjų ir žmogiškujų išteklių (rodiklių vartotoju aptarnavimo patalpu plotas $\left(m^{2}\right)$, tenkantis 1000 gyventoju; profesionaliu bibliotekininku (viso etato ekvivalentais - VEE) skaičius 1000 gyventoju; viešosios prieigos kompiuterizuotu darbo vietu (vartotojams) skaičius 10000 gyventoju procentiliai - 0,00); jos naudojimosi biblioteka rodiklis irgi žemas: rodikliu apsilankymu (fiziniu) skaičius 1 gyventojui; virtualiu apsilankymu skaičius 1000 gyventoju; dokumentu išduočiu (fiz. vnt.) skaicius 1 gyventojui; bendras bibliotekos darbo valandu, kai biblioteka atvira vartotojui, skaicius per metus, tenkantis 1000 gyventoju procentiliai - 0,00, fondo apyvartos procentilis -0,09 (žr. 11, 26, 43 lenteles).

Varenos ir Joniškio rajonų SVB surinko vienodą procentilių sumą. Dviem ar daugiau SVB surinkus vienodą sumą, atsižvelgiama ị rodiklị paprastosios 1 apsilankymui skirtos išlaidos; kuo mažesnè šio rodiklio vertė (procentilis), tuo aukštesnè pozicija skiriama. Šios grupès biblioteku reitinge Varènos rajono SVB yra aukščiau, nes jos minèto rodiklio procentilis - 0,73, o Joniškio rajono SVB - 0,59; Širvintų ir Zarasų rajonų SVB taip pat surinko vienodą procentilių sumą, aukščiau reitinge yra Širvintų r. SVB (procentilis - 0,36), o Zarasų r. SVB procentilis - 0,18. 
41 lentelè. III dimensija. 2 grupès biblioteku našumo rodikliu verčiu procentiliais suma

\begin{tabular}{|c|c|c|c|c|c|c|}
\hline \multirow{2}{*}{$\begin{array}{l}\text { Eil } \\
\text { Nr. }\end{array}$} & \multirow{2}{*}{ SVB pavadinimas } & \multicolumn{4}{|c|}{ Procentilis } & \multirow{2}{*}{$\begin{array}{l}\text { Bendra pro- } \\
\text { centilių suma }\end{array}$} \\
\hline & & 1 rodiklis & 2 rodilklis & 3 rodilklis & 4 rodiklis & \\
\hline 1. & Alytaus r. SVB & 0,95 & 1,00 & 0,68 & 0,95 & 3,58 \\
\hline 2. & Akmenès r. SVB & 0,77 & 0,32 & 0,05 & 0,05 & 1,19 \\
\hline 3. & Anykščių r. SVB & 0,27 & 0,59 & 0,59 & 0,55 & 2,00 \\
\hline 4. & Biržų r. SVB & 0,55 & 0,55 & 0,27 & 0,41 & 1,78 \\
\hline 5. & Druskininkų SVB & 0,36 & 0,09 & 0,95 & 0,82 & 2,22 \\
\hline 6. & Elektrènų SVB & 0,09 & 0,18 & 0,86 & 0,32 & 1,45 \\
\hline 7. & Ignalinos r. SVB & 0,50 & 0,36 & 0,77 & 0,91 & 2,54 \\
\hline 8. & Joniškio r. SVB & 0,73 & 0,64 & 0,64 & 0,59 & 2,60 \\
\hline 9. & Jurbarko r. SVB & 0,82 & 0,86 & 0,55 & 0,09 & 2,32 \\
\hline 10. & Kupiškio r. SVB & 0,64 & 0,27 & 0,18 & 0,14 & 1,23 \\
\hline 11. & Lazdijų r. SVB & 0,32 & 0,91 & 0,09 & 0,23 & 1,55 \\
\hline 12. & Molètų r. SVB & 0,00 & 0,95 & 0,32 & 0,77 & 2,04 \\
\hline 13. & Palangos SVB & 0,05 & 0,05 & 1,00 & 0,86 & 1,96 \\
\hline 14. & Pakruojo r. SVB & 0,18 & 0,41 & 0,50 & 0,64 & 1,73 \\
\hline 15. & Pasvalio r. SVB & 1,00 & 0,68 & 0,82 & 1,00 & 3,50 \\
\hline 16. & Prienų r. SVB & 0,45 & 0,50 & 0,23 & 0,50 & 1,68 \\
\hline 17. & Skuodo r. SVB & 0,41 & 0,82 & 0,14 & 0,45 & 1,82 \\
\hline 18. & Šilalès r. SVB & 0,23 & 0,73 & 0,36 & 0,27 & 1,59 \\
\hline 19. & Širvintų r. SVB & 0,59 & 0,77 & 0,00 & 0,36 & 1,72 \\
\hline 20. & Švenčionių r. SVB & 0,86 & 0,14 & 0,45 & 0,68 & 2,13 \\
\hline 21. & Varėnos r. SVB & 0,91 & 0,23 & 0,73 & 0,73 & 2,60 \\
\hline 22. & Visagino SVB & 0,14 & 0,00 & 0,91 & 0,00 & 1,05 \\
\hline 23. & Zarasų r. SVB & 0,68 & 0,45 & 0,41 & 0,18 & 1,72 \\
\hline
\end{tabular}

1 rodiklis - fondui komplektuoti skirtos lèsos, tenkančios 1 išduočiai;

2 rodiklis - darbuotoju darbo valandu ir valandu, per kurias biblioteka atvira lankytojams, santykis; 3 rodiklis - apsilankymu skaičius per 1 bibliotekos darbo (kai ji atvira lankytojui) valanda; 4 rodiklis - paprastosios 1 apsilankymui skirtos išlaidos. 
42 lentelè. III dimensija. 2 grupès bibliotekų bendrasis našumo rodikliu verčiu procentilis

\begin{tabular}{|c|c|c|c|c|}
\hline $\begin{array}{l}\text { Eil. } \\
\text { Nr. }\end{array}$ & SVB pavadinimas & $\begin{array}{l}\text { Procentilių } \\
\text { suma }\end{array}$ & $\begin{array}{l}\text { Procentilių suma, } \\
\text { padalyta iš } 4\end{array}$ & $\begin{array}{l}\text { Galutinis } \\
\text { procentilis }\end{array}$ \\
\hline 1. & Visagino SVB & 1,05 & 0,263 & 0,00 \\
\hline 2. & Akmenès r. SVB & 1,19 & 0,298 & 0,05 \\
\hline 3. & Kupiškio r. SVB & 1,23 & 0,308 & 0,09 \\
\hline 4. & Elektrėnų SVB & 1,45 & 0,363 & 0,14 \\
\hline 5. & Lazdijų r. SVB & 1,55 & 0,388 & 0,18 \\
\hline 6. & Šilalès r. SVB & 1,59 & 0,398 & 0,23 \\
\hline 7. & Prienų r. SVB & 1,68 & 0,420 & 0,27 \\
\hline 8. & Širvintų r. SVB & 1,72 & 0,430 & 0,32 \\
\hline 9. & Zarasų r. SVB & 1,72 & 0,430 & 0,32 \\
\hline 10. & Pakruojo r. SVB & 1,73 & 0,433 & 0,41 \\
\hline 11. & Biržų r. SVB & 1,78 & 0,445 & 0,45 \\
\hline 12. & Skuodo r. SVB & 1,82 & 0,455 & 0,50 \\
\hline 13. & Palangos SVB & 1,96 & 0,490 & 0,55 \\
\hline 14. & Anykščių r. SVB & 2,00 & 0,500 & 0,59 \\
\hline 15. & Molètų r. SVB & 2,04 & 0,510 & 0,64 \\
\hline 16. & Švenčionių r. SVB & 2,13 & 0,533 & 0,68 \\
\hline 17. & Druskininkų SVB & 2,22 & 0,555 & 0,73 \\
\hline 18. & Jurbarko r. SVB & 2,32 & 0,580 & 0,77 \\
\hline 19. & Ignalinos r. SVB & 2,54 & 0,635 & 0,82 \\
\hline 20. & Joniškio r. SVB & 2,60 & 0,650 & 0,86 \\
\hline 21. & Varènos r. SVB & 2,60 & 0,650 & 0,86 \\
\hline 22. & Pasvalio r. SVB & 3,50 & 0,875 & 0,95 \\
\hline 23. & Alytaus r. SVB & 3,58 & 0,895 & 1,00 \\
\hline
\end{tabular}

43 lentelè. III dimensija. 2 grupès biblioteku našumo įvertinimas

\begin{tabular}{|c|l|c|c|c|c|}
$\begin{array}{c}\text { Eil. } \\
\text { Nr. }\end{array}$ & \multicolumn{1}{|c|}{ SVB pavadinimas } & $\begin{array}{c}\text { Procentilių } \\
\text { suma }\end{array}$ & $\begin{array}{c}\text { Procentilių suma, } \\
\text { padalyta iš } 4\end{array}$ & $\begin{array}{c}\text { Galutinis } \\
\text { procentilis }\end{array}$ \\
\hline 1. & Alytaus r. SVB & 3,58 & 0,895 & 1,00 & $\star$ \\
\hline 2. & Pasvalio r. SVB & 3,50 & 0,875 & 0,95 & $\star$ \\
\hline 3. & Varènos r. SVB & 2,60 & 0,650 & 0,86 & $\star$ \\
\hline 4. & Joniškio r. SVB & 2,60 & 0,650 & 0,86 & $\star$ \\
\hline
\end{tabular}




\begin{tabular}{|c|c|c|c|c|}
\hline $\begin{array}{l}\text { Eil. } \\
\text { Nr. }\end{array}$ & SVB pavadinimas & $\begin{array}{l}\text { Procentilių } \\
\text { suma }\end{array}$ & $\begin{array}{c}\text { Procentilių suma, } \\
\text { padalyta iš } 4\end{array}$ & $\begin{array}{l}\text { Galutinis } \\
\text { procentilis }\end{array}$ \\
\hline 5. & Ignalinos r. SVB & 2,54 & 0,635 & 0,82 \\
\hline 6. & Jurbarko r. SVB & 2,32 & 0,580 & 0,77 \\
\hline 7. & Druskininkų SVB & 2,22 & 0,555 & 0,73 \\
\hline 8. & Švenčionių r. SVB & 2,13 & 0,533 & 0,68 \\
\hline 9. & Molètų r. SVB & 2,04 & 0,510 & 0,64 \\
\hline 10. & Anykščių r. SVB & 2,00 & 0,500 & 0,59 \\
\hline 11. & Palangos SVB & 1,96 & 0,490 & 0,55 \\
\hline 12. & Skuodo r. SVB & 1,82 & 0,455 & 0,50 \\
\hline 13. & Biržų r. SVB & 1,78 & 0,445 & 0,45 \\
\hline 14. & Pakruojo r. SVB & 1,73 & 0,433 & 0,41 \\
\hline 15. & Širvintų r. SVB & 1,72 & 0,430 & 0,32 \\
\hline 16. & Zarasų r. SVB & 1,72 & 0,430 & 0,32 \\
\hline 17. & Prienų r. SVB & 1,68 & 0,420 & 0,27 \\
\hline 18. & Šilalès r. SVB & 1,59 & 0,398 & 0,23 \\
\hline 19. & Lazdijų r. SVB & 1,55 & 0,388 & 0,18 \\
\hline 20. & Elektrènų SVB & 1,45 & 0,363 & 0,14 \\
\hline 21. & Kupiškio r. SVB & 1,23 & 0,308 & 0,09 \\
\hline 22. & Akmenès r. SVB & 1,19 & 0,298 & 0,05 \\
\hline 23. & Visagino SVB & 1,05 & 0,263 & 0,00 \\
\hline
\end{tabular}

3 grupè. I aukščiausią grupę pateko ir po žvaigždę gavo Rokiškio, Telšių, Šilutès, Plungès, Trakų, Jonavos rajonų SVB (žr. 46 lentelę). Rokiškio rajono SVB pagal I, II ir III dimensijų rodiklius pateko į auksinę grupę, todèl pagal BIX metodiką paslaugu ir naudojimosi jomis santykis vertinamas geriausiai.

Vidurinëje grupèje yra ir po pusę žvaigždès pelnè Kaišiadorių, Radviliškio, Šalčininku, Utenos, Ukmergès, Kelmès ir Panevežzio rajonų SVB. Gerų rezultatų pasiekè Radviliškio, Utenos, Panevěžio rajonų SVB: I dimensijos požiūriu Panevėžio r. SVB procentilis - 0,94, Radviliškio $r$. SVB - 0,83, Utenos r. SVB - 0,78; pagal II dimensijos rodiklius Utenos r. SVB procentilis - 0,94, Panevėžio r. SVB - 0,83, Radviliškio r. SVB - 0,78; visos išvardytos SVB I ir II dimensijose pateko į auksinę grupę. Bibliotekų 
našumą išreiškiantys rodikliai tiesiogiai susiję su naudojimusi bibliotekos paslaugomis, todèl aukščiausius vertinimus gavo tos bibliotekos, kurių paslaugomis gyventojai naudojasi intensyviausiai (žr. 16, 31, 46 lenteles).

Žemiausioje grupëje liko Šakių, Vilkaviškio, Raseiniu, Kretingos, Tauragès ir Šiaulių rajonų SVB (̌̌r. 46 lentelę).

44 lentelè. III dimensija. 3 grupès biblioteku našumo rodikliu verčiu procentiliais suma

\begin{tabular}{|c|c|c|c|c|c|c|}
\hline \multirow{2}{*}{$\begin{array}{l}\text { Eil } \\
\text { Nr. }\end{array}$} & \multirow{2}{*}{ SVB pavadinimas } & \multicolumn{4}{|c|}{ Procentilis } & \multirow{2}{*}{$\begin{array}{l}\text { Bendra pro- } \\
\text { centilių suma }\end{array}$} \\
\hline & & 1 rodiklis & 2 rodiklis & 3 rodiklis & 4 rodiklis & \\
\hline 1. & Jonavos r. SVB & 0,83 & 0,00 & 0,94 & 0,72 & 2,49 \\
\hline 2. & Kaišiadorių r. SVB & 0,17 & 0,78 & 0,67 & 0,83 & 2,45 \\
\hline 3. & Kelmės r. SVB & 0,67 & 0,44 & 0,50 & 0,44 & 2,05 \\
\hline 4. & Kretingos r. SVB & 0,33 & 0,06 & 0,56 & 0,11 & 1,06 \\
\hline 5. & Panevėžio r. SVB & 0,56 & 0,94 & 0,33 & 0,17 & 2,00 \\
\hline 6. & Plungès r.SVB & 0,22 & 0,72 & 0,78 & 0,89 & 2,61 \\
\hline 7. & Radviliškio r. SVB & 0,44 & 1,00 & 0,17 & 0,78 & 2,39 \\
\hline 8. & Raseinių r. SVB & 0,11 & 0,33 & 0,44 & 0,22 & 1,10 \\
\hline 9. & Rokiškio r. SVB & 1,00 & 0,67 & 0,61 & 1,00 & 3,28 \\
\hline 10. & Šakių r. SVB & 0,50 & 0,39 & 0,28 & 0,33 & 1,50 \\
\hline 11. & Šalčininkų r. SVB & 0,72 & 0,83 & 0,11 & 0,61 & 2,27 \\
\hline 12. & Šiaulių r. SVB & 0,06 & 0,17 & 0,00 & 0,00 & 0,23 \\
\hline 13. & Šilutès r. SVB & 0,94 & 0,22 & 0,89 & 0,67 & 2,72 \\
\hline 14. & Tauragès r. SVB & 0,00 & 0,50 & 0,06 & 0,06 & 0,62 \\
\hline 15. & Telšių r. SVB & 0,39 & 0,89 & 0,72 & 0,94 & 2,94 \\
\hline 16. & Trakų r. SVB & 0,89 & 0,28 & 0,83 & 0,56 & 2,56 \\
\hline 17. & Ukmergès r. SVB & 0,78 & 0,56 & 0,39 & 0,39 & 2,12 \\
\hline 18. & Utenos r. SVB & 0,61 & 0,11 & 1,00 & 0,50 & 2,22 \\
\hline 19. & Vilkaviškio r. SVB & 0,28 & 0,61 & 0,22 & 0,28 & 1,39 \\
\hline
\end{tabular}

1 rodiklis - fondui komplektuoti skirtos lésos, tenkančios 1 išduočiai;

2 rodiklis - darbuotoju darbo valandu ir valandu, per kurias biblioteka atvira lankytojams, santykis;

3 rodiklis - apsilankymu skaičius per 1 bibliotekos darbo (kai ji atvira lankytojui) valanda;

4 rodiklis - paprastosios 1 apsilankymui skirtos išlaidos. 
45 lentelè. III dimensija. 3 grupes bibliotekų bendrasis našumo rodikliu verčiu procentilis

\begin{tabular}{|c|c|c|c|c|}
\hline $\begin{array}{l}\text { Eil. } \\
\text { Nr. }\end{array}$ & SVB pavadinimas & $\begin{array}{l}\text { Procentilių } \\
\text { suma }\end{array}$ & $\begin{array}{l}\text { Procentilių suma, } \\
\text { padalyta iš } 4\end{array}$ & $\begin{array}{l}\text { Galutinis } \\
\text { procentilis }\end{array}$ \\
\hline 1. & Šiaulių r. SVB & 0,23 & 0,060 & 0,00 \\
\hline 2. & Tauragès r. SVB & 0,62 & 0,160 & 0,06 \\
\hline 3. & Kretingos r. SVB & 1,06 & 0,270 & 0,11 \\
\hline 4. & Raseinių r. SVB & 1,10 & 0,280 & 0,17 \\
\hline 5. & Vilkaviškio r. SVB & 1,39 & 0,348 & 0,22 \\
\hline 6. & Šakių r. SVB & 1,50 & 0,380 & 0,28 \\
\hline 7. & Panevėžio r. SVB & 2,00 & 0,500 & 0,33 \\
\hline 8. & Kelmès r. SVB & 2,05 & 0,510 & 0,39 \\
\hline 9. & Ukmergès r. SVB & 2,12 & 0,530 & 0,44 \\
\hline 10. & Utenos r. SVB & 2,22 & 0,560 & 0,50 \\
\hline 11. & Šalčininkų r. SVB & 2,27 & 0,570 & 0,56 \\
\hline 12. & Kaišiadorių r. SVB & 2,45 & 0,613 & 0,67 \\
\hline 13. & Radviliškio r. SVB & 2,39 & 0,600 & 0,61 \\
\hline 14. & Jonavos r. SVB & 2,49 & 0,620 & 0,72 \\
\hline 15. & Trakų r. SVB & 2,56 & 0,640 & 0,78 \\
\hline 16. & Plungės r. SVB & 2,61 & 0,650 & 0,83 \\
\hline 17. & Šilutès r. SVB & 2,72 & 0,680 & 0,89 \\
\hline 18. & Telšių r. SVB & 2,94 & 0,735 & 0,94 \\
\hline 19. & Rokiškio r. SVB & 3,28 & 0,820 & 1,00 \\
\hline
\end{tabular}

46 lentelè. III dimensija. 3 grupès bibliotekų našumo įvertinimas

\begin{tabular}{|c|c|c|c|c|}
\hline $\begin{array}{l}\text { Eil. } \\
\text { Nr. }\end{array}$ & SVB pavadinimas & $\begin{array}{l}\text { Procentilių } \\
\text { suma }\end{array}$ & $\begin{array}{l}\text { Procentilių suma, } \\
\text { padalyta iš } 4\end{array}$ & $\begin{array}{l}\text { Galutinis } \\
\text { procentilis }\end{array}$ \\
\hline 1. & Rokiškio r. SVB & 3,28 & 0,820 & 1,00 \\
\hline 2. & Telšių r. SVB & 2,94 & 0,740 & 0,94 \\
\hline 3. & Šilutès r. SVB & 2,72 & 0,680 & 0,89 \\
\hline 4. & Plungès r. SVB & 2,61 & 0,650 & 0,83 \\
\hline 5. & Trakų r. SVB & 2,56 & 0,640 & 0,78 \\
\hline 6. & Jonavos r. SVB & 2,49 & 0,620 & 0,72 \\
\hline 7. & Kaišiadorių r. SVB & 2,45 & 0,613 & 0,67 \\
\hline 8. & Radviliškio r. SVB & 2,39 & 0,600 & 0,61 \\
\hline 9. & Šalčininkų r. SVB & 2,27 & 0,570 & 0,56 \\
\hline
\end{tabular}




\begin{tabular}{|c|c|c|c|c|}
\hline $\begin{array}{l}\text { Eil. } \\
\text { Nr. }\end{array}$ & SVB pavadinimas & $\begin{array}{l}\text { Procentilių } \\
\text { suma }\end{array}$ & $\begin{array}{c}\text { Procentilių suma, } \\
\text { padalyta iš } 4\end{array}$ & $\begin{array}{l}\text { Galutinis } \\
\text { procentilis }\end{array}$ \\
\hline 10. & Utenos r. SVB & 2,22 & 0,560 & 0,50 \\
\hline 11. & Ukmergès r. SVB & 2,12 & 0,530 & 0,44 \\
\hline 12. & Kelmės r. SVB & 2,05 & 0,510 & 0,39 \\
\hline 13. & Panevėžio r. SVB & 2,00 & 0,500 & 0,33 \\
\hline 14. & Šakių r. SVB & 1,50 & 0,380 & 0,28 \\
\hline 15. & Vilkaviškio r. SVB & 1,39 & 0,348 & 0,22 \\
\hline 16. & Raseinių r. SVB & 1,10 & 0,280 & 0,17 \\
\hline 17. & Kretingos r. SVB & 1,06 & 0,270 & 0,11 \\
\hline 18. & Tauragès r. SVB & 0,62 & 0,160 & 0,06 \\
\hline 19. & Šiaulių r. SVB & 0,23 & 0,060 & 0,00 \\
\hline
\end{tabular}

4 grupè. İ aukščiausią grupę pateko ir po žvaigždę gavo Kèdainių rajono, Alytaus ir Panevėžio miestų SVB (žr. 49 lentelę).

Kèdainių rajono SVB pagal I, II ir III dimensijų rezultatus yra aukščiausioje grupeje (procentiliai - 1,00). III dimensijoje rodiklių fondui komplektuoti skirtos lèsos, tenkančios 1 išduočiai, ir paprastosios 1 apsilankymui skirtos išlaidos procentiliai - 1,00. Kèdainių r. SVB sugeba tinkamai panaudoti turimus išteklius, pagal naudojimosi biblioteka rodiklius ji yra ivertinta aukščiausiai, be to, ši SVB tinkamai paskirsto darbo sąnaudas ir investuoja gaunamas lèšas (žr. 19, 34, 47, 49 lenteles).

I vidurinę grupę pateko ir po pusę žvaigždès laimëjo Klaipèdos rajono ir Marijampolès SVB, o žemiausioje grupeje liko Mažeikių, Kauno ir Vilniaus rajonų SVB (žr. 49 lentelę). Pasatarosios ịstaigos rezultatas yra proporcingas I ir II dimensijų rodikliais pasiektiems rezultatams: visose trijose dimensijose Vilniaus rajono SVB pateko ị žemiausiąją grupę; Kauno r. SVB su I ir II dimensiju rodikliais atsidūrè vidurinèje grupèje; Mažeikių r. SVB I dimensijos požiūriu pateko ị vidurinę grupę, II dimensijos - $\mathrm{i}$ žemiausią grupę.

Alytaus ir Panevėžio miestų SVB surinko vienodą procentilių sumą; aukščiau reitinge yra Alytaus m. SVB, nes jos rodiklio paprastosios 1 apsilankymui skirtos lèšs procentilis - 0,86, Panevėžio m. SVB - 0,71. 
47 lentelè. III dimensija. 4 grupè bibliotekų našumo rodikliu verčiu procentiliais suma

\begin{tabular}{|c|c|c|c|c|c|c|}
\hline \multirow{2}{*}{$\begin{array}{l}\text { Eil } \\
\text { Nr. }\end{array}$} & \multirow{2}{*}{ SVB pavadinimas } & \multicolumn{4}{|c|}{ Procentilis } & \multirow{2}{*}{$\begin{array}{l}\text { Bendra pro- } \\
\text { centilių suma }\end{array}$} \\
\hline & & 1 rodiklis & 2 rodiklis & 3 rodiklis & 4 rodiklis & \\
\hline 1. & Alytaus m. SVB & 0,71 & 0,00 & 1,00 & 0,86 & 2,57 \\
\hline 2. & Kauno r. SVB & 0,14 & 0,71 & 0,43 & 0,14 & 1,42 \\
\hline 3. & Kèdainių r. SVB & 1,00 & 0,29 & 0,57 & 1,00 & 2,86 \\
\hline 4. & Klaipedos r. SVB & 0,57 & 1,00 & 0,29 & 0,57 & 2,43 \\
\hline 5. & Marijampolès SVB & 0,29 & 0,43 & 0,71 & 0,43 & 1,86 \\
\hline 6. & Mažeikių r. SVB & 0,43 & 0,57 & 0,14 & 0,29 & 1,43 \\
\hline 7. & Panevėžio $\mathrm{m}$. SVB & 0,86 & 0,14 & 0,86 & 0,71 & 2,57 \\
\hline 8. & Vilniaus r. SVB & 0,00 & 0,86 & 0,00 & 0,00 & 0,86 \\
\hline
\end{tabular}

1 rodiklis - fondui komplektuoti skirtos lësos, tenkančios 1 išduočiai;

2 rodiklis - darbuotoju darbo valandu ir valandu, per kurias biblioteka atvira lankytojams, santykis;

3 rodiklis - apsilankymu skaičius per 1 bibliotekos darbo (kai ji atvira lankytojui) valanda;

4 rodiklis - paprastosios 1 apsilankymui skirtos išlaidos.

48 lentelè. III dimensija. 4 grupès biblioteku bendrasis našumo rodikliu verčiu procentilis

\begin{tabular}{|c|l|c|c|c|}
\hline $\begin{array}{c}\text { Eil. } \\
\text { Nr. }\end{array}$ & \multicolumn{1}{|c|}{ SVB pavadinimas } & $\begin{array}{c}\text { Procentilių } \\
\text { suma }\end{array}$ & $\begin{array}{c}\text { Procentilių suma, } \\
\text { padalyta iš 4 }\end{array}$ & $\begin{array}{c}\text { Galutinis } \\
\text { procentilis }\end{array}$ \\
\hline 1. & Vilniaus r. SVB & 0,86 & 0,215 & 0,00 \\
\hline 2. & Kauno r. SVB & 1,42 & 0,355 & 0,14 \\
\hline 3. & Mažeikių r. SVB & 1,43 & 0,358 & 0,29 \\
\hline 4. & Marijampolès SVB & 1,86 & 0,465 & 0,43 \\
\hline 5. & Klaipédos r. SVB & 2,43 & 0,608 & 0,57 \\
\hline 6. & Panevèžio m. SVB & 2,57 & 0,643 & 0,71 \\
\hline 7. & Alytaus m. SVB & 2,57 & 0,643 & 0,71 \\
\hline 8. & Kèdainių r. SVB & 2,86 & 0,715 & 1,00 \\
\hline
\end{tabular}

49 lentelè. III dimensija. 4 grupès biblioteku našumo įvertinimas

\begin{tabular}{|c|c|c|c|c|}
\hline $\begin{array}{l}\text { Eil. } \\
\text { Nr. }\end{array}$ & SVB pavadinimas & $\begin{array}{l}\text { Procentilių } \\
\text { suma }\end{array}$ & $\begin{array}{l}\text { Procentilių suma, } \\
\text { padalyta iš } 4\end{array}$ & $\begin{array}{l}\text { Galutinis } \\
\text { procentilis }\end{array}$ \\
\hline 1. & Këdainių r. SVB & 2,86 & 0,715 & 1,00 \\
\hline 2. & Alytaus m. SVB & 2,57 & 0,643 & 0,71 \\
\hline 3. & Panevėžio $\mathrm{m}$. SVB & 2,57 & 0,643 & 0,71 \\
\hline 4. & Klaipèdos r. SVB & 2,43 & 0,608 & 0,57 \\
\hline 5. & Marijampolès SVB & 1,86 & 0,465 & 0,43 \\
\hline 6. & Mažeikių r. SVB & 1,43 & 0,358 & 0,29 \\
\hline 7. & Kauno r. SVB & 1,42 & 0,355 & 0,14 \\
\hline 8. & Vilniaus r. SVB & 0,86 & 0,215 & 0,00 \\
\hline
\end{tabular}


5 grupè. It aukščiausią grupę pateko ir po žvaigždę gavo Klaipėdos ir Vilniaus miestų SVB (žr. 52 lentelę). Atkreiptinas dèmesys ị tai, kad Klaipedos m. SVB rezultatai ir I dimensijos, ir II dimensijos rodikliais yra tolygūs: pateko į aukščiausią grupę ir pelnè po žvaigždę, o šios dimensijos rezultatas tik patvirtina uostamiesčio bibliotekos pranašumą tarp kitu grupès biblioteku.

I vidurinę grupę pateko ir pusę žvaigždès gavo Kauno miesto SVB.

Remiantis BIX metodika, Šiaulių miesto SVB veiklos našumas vertinamas žemiausiai, nors, vertinant I dimensijos (Ištekliai ir infrastruktūra) rodiklių požiūriu, ji pateko ị auksinę grupę, o II dimensijos (Naudojimasis biblioteka) - i vidurinę grupę (žr. 22, 37, 52 lenteles).

50 lentelè. III dimensija. 5 grupès biblioteku našumo rodikliu verčiu procentiliais suma

\begin{tabular}{|c|c|c|c|c|c|c|}
\hline \multirow{2}{*}{$\begin{array}{l}\text { Eil } \\
\text { Nr. }\end{array}$} & \multirow[b]{2}{*}{ SVB pavadinimas } & \multicolumn{4}{|c|}{ Procentilis } & \multirow{2}{*}{$\begin{array}{l}\text { Bendra pro- } \\
\text { centilių suma }\end{array}$} \\
\hline & & $\begin{array}{l}1 \text { rodik- } \\
\text { lis }\end{array}$ & $\begin{array}{l}2 \text { rodik- } \\
\text { lis }\end{array}$ & $\begin{array}{c}3 \text { rodik- } \\
\text { lis }\end{array}$ & $\begin{array}{l}4 \text { rodik- } \\
\text { lis }\end{array}$ & \\
\hline 1. & Kauno m. SVB & 1,00 & 0,67 & 0,00 & 0,00 & 1,67 \\
\hline 2. & Klaipèdos m. SVB & 0,00 & 1,00 & 0,67 & 1,00 & 2,67 \\
\hline 3. & Šiaulių m. SVB & 0,67 & 0,00 & 0,33 & 0,33 & 1,33 \\
\hline 4. & Vilniaus $\mathrm{m}$. SVB & 0,33 & 0,33 & 1,00 & 0,67 & 2,33 \\
\hline
\end{tabular}

1 rodiklis - fondui komplektuoti skirtos lëšs, tenkančios 1 išduočiai;

2 rodiklis - darbuotoju darbo valandu ir valandu, per kurias biblioteka atvira lankytojams, santykis;

3 rodiklis - apsilankymu skaičius per 1 bibliotekos darbo (kai ji atvira lankytojui) valanda;

4 rodiklis - paprastosios 1 apsilankymui skirtos iślaidos.

51 lentelè. III dimensija. 5 grupès biblioteku bendrasis našumo rodikliu verčiu procentilis

\begin{tabular}{|c|l|c|c|c|}
\hline $\begin{array}{c}\text { Eil. } \\
\text { Nr. }\end{array}$ & \multicolumn{1}{|c|}{ SVB pavadinimas } & $\begin{array}{c}\text { Procentilių } \\
\text { suma }\end{array}$ & $\begin{array}{c}\text { Procentilių suma, } \\
\text { padalyta ǐ } 4\end{array}$ & $\begin{array}{c}\text { Galutinis } \\
\text { procentilis }\end{array}$ \\
\hline 1. & Šiaulių m. SVB & 1,33 & 0,333 & 0,00 \\
\hline 2. & Kauno m. SVB & 1,67 & 0,418 & 0,33 \\
\hline 3. & Vilniaus m. SVB & 2,33 & 0,583 & 0,67 \\
\hline 4. & Klaipėdos m. SVB & 2,67 & 0,668 & 1,00 \\
\hline
\end{tabular}


52 lentelè. III dimensija. 5 grupès bibliotekų našumo įvertinimas

\begin{tabular}{|c|c|c|c|c|}
\hline $\begin{array}{l}\text { Eil. } \\
\text { Nr. }\end{array}$ & SVB pavadinimas & $\begin{array}{l}\text { Procentilių } \\
\text { suma }\end{array}$ & $\begin{array}{l}\text { Procentilių suma } \\
\text { padalinta iš } 4\end{array}$ & $\begin{array}{l}\text { Galutinis } \\
\text { procentilis }\end{array}$ \\
\hline 1. & Klaipèdos m. SVB & 2,67 & 0,668 & 1,00 \\
\hline 2. & Vilniaus $\mathrm{m}$. SVB & 2,33 & 0,583 & 0,67 \\
\hline 3. & Kauno m. SVB & 1,67 & 0,418 & 0,33 \\
\hline 4. & Šiaulių m. SVB & 1,33 & 0,333 & 0,00 \\
\hline
\end{tabular}

\section{IV dimensija. Plètra}

Šioje dimensijoje vertinami 3 rodikliai, kurie susiję su dokumentų fondo atnaujinimu, bibliotekos darbuotojų kompetencijų ugdymu ir bibliotekos infrastruktūros gerinimu. Pateikiami šios dimensijos bibliotekų 1, 2, 3, 4, 5 grupių rezultatai bei jų reitingai.

1 grupè. I aukščiausią auksinę grupę pateko ir po žvaigždę pelnè Rietavo ir Kazlų Rūdos SVB. Lyderès pozicijas užèmusios Rietavo SVB rodiklių 1 darbuotojo mokymams skirtu valandu skaičius ir nepaprastosios išlaidos 1 gyventojui vertes procentiliai - 1,00; fondo atnaujinimo procento0,60 (žr. 55 lentelę).

Birštono ir Kalvarijos SVB pateko ị vidurinę grupę ir pelnè po pusę žvaigždès. Birštono SVB rodiklių 1 darbuotojo mokymams skirtu valandu skaičius ir nepaprastosios lésos 1 gyventojui procentilis - 0,80. O fondo atnaujinimo procentas yra vienas žemiausių (procentilis $-0,20$ ). Šis rodiklis turètų paskatinti šią SVB daugiau dèmesio skirti fondo komplektavimo, jo kokybės ir atnaujinimo reikalams. Birštono biblioteka yra sukaupusi didelị fondą, o nauju gautų dokumentų procentas yra vienas mažiausių šioje biblioteku grupejje (53 lentelè).

Kalvarijos SVB rodikliu fondo atnaujinimo procentas procentilis 0,80 , nepaprastosios léšs 1 gyventojui - 0,40 procentilio, o štai 1 darbuotojo mokymams skirtu valandu skaičiaus procentilis - tik 0,20. Mokymams skirtų valandų skaičius yra vienas mažiausių grupejje, nors šios bibliotekos darbuotojų skaičius yra didžiausias grupejje. 
Žemiausi rodikliai yra Neringos ir Pagègiu SVB. Pastarosios nepaprastosios išlaidos 1 gyventojui yra nulinès, atitinkamai ir procentilis yra 0,00, o fondo atnaujinimo procentas yra pats žemiausias šioje grupëje (procentilis - 0,00). Pagègiu SVB pagal kitas dimensijas buvo tarp lyderių: su I ir III dimensijų rodikliais pateko ị auksinę grupę, o II dimensijoje pelnè pusę žvaigždès. IV dimensijoje, kuri pagal BIX metodiką yra siejama su dokumentų fondo atnaujinimu, bibliotekos darbuotoju kompetenciju ugdymu ir bibliotekos infrastruktūros gerinimu, Pagegiu SVB galimybès buvo įvertintos prasčiausiai (žr. 10, 25, 40, 53 lenteles).

53 lentelè. IV dimensija. 1 grupès biblioteku plètros rodikliu verčiu procentiliais suma

\begin{tabular}{|c|l|c|c|c|c|}
\hline \multirow{2}{*}{ Eil. } & \multirow{2}{*}{ SVB pavadinimas } & \multicolumn{3}{|c|}{ Procentilis } & Bendra pro- \\
\cline { 3 - 5 } & & 1 rodiklis & 2 rodiklis & 3 rodiklis & centilių suma \\
\hline 1. & Birštono SVB & 0,20 & 0,80 & 0,80 & 1,80 \\
\hline 2. & Kalvarijos SVB & 0,80 & 0,20 & 0,40 & 1,40 \\
\hline 3. & Kazlų Rūdos SVB & 1,00 & 0,60 & 0,60 & 2,20 \\
\hline 4. & Neringos SVB & 0,40 & 0,00 & 0,00 & 0,60 \\
\hline 5. & Pagègių SVB & 0,00 & 0,40 & 0,00 & 0,40 \\
\hline 6. & Rietavo SVB & 0,60 & 1,00 & 1,00 & 2,60 \\
\hline
\end{tabular}

1 rodiklis - fondo atnaujinimo procentas;

2 rodiklis - 1 darbuotojo mokymams skirtu valandu skaičius;

3 rodiklis - nepaprastosios išlaidos 1 gyventojui.

54 lentelè. IV dimensija. 1 grupès biblioteku bendrasis pletros rodikliu verčiu procentilis

\begin{tabular}{|c|l|c|c|c|}
\hline $\begin{array}{c}\text { Eil. } \\
\text { Nr. }\end{array}$ & \multicolumn{1}{|c|}{ SVB pavadinimas } & $\begin{array}{c}\text { Procentilių } \\
\text { suma }\end{array}$ & $\begin{array}{c}\text { Procentilių suma, } \\
\text { padalyta iš 3 }\end{array}$ & $\begin{array}{c}\text { Galutinis } \\
\text { procentilis }\end{array}$ \\
\hline 1. & Pagègių SVB & 0,40 & 0,133 & 0,00 \\
\hline 2. & Neringos SVB & 0,60 & 0,200 & 0,20 \\
\hline 3. & Kalvarijos SVB & 1,40 & 0,467 & 0,40 \\
\hline 4. & Birštono SVB & 1,80 & 0,600 & 0,60 \\
\hline 5. & Kazlų Rūdos SVB & 2,20 & 0,733 & 0,80 \\
\hline 6. & Rietavo SVB & 2,60 & 0,867 & 1,00 \\
\hline
\end{tabular}


55 lentelè. IV dimensija. 1 grupes biblioteku plètros įvertinimas

\begin{tabular}{|c|l|c|c|c|c|} 
Eil. & \multicolumn{1}{|c|}{ SVB pavadinimas } & $\begin{array}{c}\text { Procentilių } \\
\text { suma }\end{array}$ & $\begin{array}{c}\text { Procentilių suma, } \\
\text { padalyta iš } 3\end{array}$ & $\begin{array}{c}\text { Galutinis } \\
\text { procentilis }\end{array}$ \\
\hline 1. & Rietavo SVB & 2,60 & 0,867 & 1,00 & $\star$ \\
\hline 2. & Kazlų Rūdos SVB & 2,20 & 0,733 & 0,80 & $\star$ \\
\hline 3. & Birštono SVB & 1,80 & 0,600 & 0,60 & 丸 \\
\hline 4. & Kalvarijos SVB & 1,40 & 0,467 & 0,40 & 丸 \\
\hline 5. & Neringos SVB & 0,60 & 0,200 & 0,20 \\
\hline 6. & Pagègių SVB & 0,40 & 0,133 & 0,00 \\
\hline
\end{tabular}

2 grupè. İ aukščiausią grupę pateko ir po žvaigždę pelnè Molètų, Zarasų, Joniškio, Jurbarko, Pasvalio, Anykščių, Ignalinos rajonų bei Elektrènų SVB (̌̌r. 58 lentelę).

Molètu rajono SVB rodikliu ịverčiai svyravo nuo 0,55 (nepaprastosios išlaidos 1 gyventojui) iki 1,00 procentilio (1 darbuotojo mokymams skirtu valandu skaicius). Zarasu rajono SVB geriausiai įvertinti rodikliai yra 1 darbuotojo mokymams skirtu valandu skaičius procentilis - 0,95; nepaprastosios išlaidos 1 gyventojui - 0,86 (56 lentelè).

Kupiškio, Prienų, Biržų, Alytaus rajonų ir Druskininkų SVB pateko i vidurinę grupę ir gavo po pusę žvaigždès. Kupiškio rajono SVB rodiklių vertès - nuo 0,41 (fondo atnaujinimo procentas) iki 0,82 procentilio (nepaprastosios išlaidos 1 gyventojui). Prienų ir Biržų rajonų SVB surinko vienodą procentilių sumą $(0,55)$; reitinguojant bibliotekas, esant vienodai visų rodikliu procentilių sumai, bibliotekos vietai reitinge svarbus fondo atnaujinimo procento rodiklis. Aukštesnè vieta suteikiama tai bibliotekai, kurios fondo atnaujinimo procento procentilis didesnis, t. y. artimesnis vienetui $(1,00)$, todèl aukštesnëje pozicijoje atsidūrè Prienų r. SVB, nes jos minèto rodiklio procentilis - 0,86, o Biržų r. SVB - 0,59 (žr. 56, 57, 58 lenteles).

Žemiausioje grupèje liko Palangos miesto, Šilalès, Varènos, Širvintų, Pakruojo, Lazdijų, Švenčionių, Akmenės, Skuodo rajonų ir Visagino SVB. Žemi ịvertinimai yra Skuodo rajono SVB: pagal rodikli fondo atnaujinimo procentas (0,00 procentilis) 100 proc. grupès biblioteku buvo aukštesnèje 
pozicijoje; pagal 1 darbuotojo mokymams skirtu valandu skaičiu (procentilis - 0,09) 91 proc. grupès bibliotekų buvo aukštesnëje vietoje, o pagal nepaprastasias islaidas 1 gyventojui (procentilis - 0,36) - 64 proc. bibliotekų (56 lentelè).

Šilalès, Varènos rajonų ir Palangos SVB surinko vienodą procentilių sumą (0,32 procentilio), tačiau aukštesnejje pozicijoje yra Šilalès r. SVB, nes rodiklio fondo atnaujinimo procentas procentilis - 0,64, Varènos $\mathrm{r}$. SVB - 0,50, Palangos SVB - 0,23 (žr. 57, 58 lenteles).

56 lentelè. IV dimensija. 2 grupès biblioteku plètros rodikliu verčiu procentiliais suma

\begin{tabular}{|c|c|c|c|c|c|}
\hline \multirow{2}{*}{$\begin{array}{l}\text { Eil. } \\
\text { Nr. }\end{array}$} & \multirow{2}{*}{ SVB pavadinimas } & \multicolumn{3}{|c|}{ Procentilis } & \multirow{2}{*}{$\begin{array}{l}\text { Bendra pro- } \\
\text { centilių suma }\end{array}$} \\
\hline & & 1 rodiklis & 2 rodiklis & 3 rodiklis & \\
\hline 1. & Alytaus r. SVB & 0,27 & 0,55 & 0,73 & 1,55 \\
\hline 2. & Akmenès r. SVB & 0,09 & 0,14 & 0,32 & 0,55 \\
\hline 3. & Anykščių r. SVB & 0,77 & 0,18 & 0,91 & 1,86 \\
\hline 4. & Biržų r. SVB & 0,59 & 0,23 & 0,77 & 1,59 \\
\hline 5. & Druskininkų SVB & 0,32 & 0,68 & 0,41 & 1,41 \\
\hline 6. & Elektrėnų SVB & 0,82 & 0,36 & 0,64 & 1,82 \\
\hline 7. & Ignalinos r. SVB & 1,00 & 0,27 & 0,50 & 1,77 \\
\hline 8. & Joniškio r. SVB & 0,91 & 0,91 & 0,59 & 2,41 \\
\hline 9. & Jurbarko r. SVB & 0,73 & 0,36 & 1,00 & 2,09 \\
\hline 10. & Kupiškio r. SVB & 0,41 & 0,50 & 0,82 & 1,73 \\
\hline 11. & Lazdijų r. SVB & 0,18 & 0,77 & 0,00 & 0,95 \\
\hline 12. & Molètų r. SVB & 0,95 & 1,00 & 0,55 & 2,50 \\
\hline 13. & Palangos SVB & 0,23 & 0,64 & 0,45 & 1,32 \\
\hline 14. & Pakruojo r. SVB & 0,36 & 0,45 & 0,27 & 1,08 \\
\hline 15. & Pasvalio r. SVB & 0,14 & 0,86 & 0,95 & 1,95 \\
\hline 16. & Prienų r. SVB & 0,86 & 0,73 & 0,00 & 1,59 \\
\hline 17. & Skuodo r. SVB & 0,00 & 0,09 & 0,36 & 0,45 \\
\hline 18. & Šilalès r. SVB & 0,64 & 0,00 & 0,68 & 1,32 \\
\hline 19. & Širvintų r. SVB & 0,55 & 0,59 & 0,00 & 1,14 \\
\hline 20. & Švenčionių r. SVB & 0,45 & 0,05 & 0,23 & 0,73 \\
\hline 21. & Varènos r. SVB & 0,50 & 0,82 & 0,00 & 1,32 \\
\hline 22. & Visagino SVB & 0,05 & 0,32 & 0,18 & 0,55 \\
\hline 23. & Zarasų r. SVB & 0,68 & 0,95 & 0,86 & 2,49 \\
\hline
\end{tabular}

1 rodiklis - fondo atnaujinimo procentas;

2 rodiklis -1 darbuotojo mokymams skirtu valandu skaičius;

3 rodiklis - nepaprastosios išlaidos 1 gyventojui. 
57 lentelè. IV dimensija. 2 grupes biblioteku bendrasis pletros rodikliu verčiu procentilis

\begin{tabular}{|c|l|c|c|c|}
\hline Eil. & \multicolumn{1}{|c|}{ SVB pavadinimas } & $\begin{array}{c}\text { Procentilių } \\
\text { suma }\end{array}$ & $\begin{array}{c}\text { Procentilių suma, } \\
\text { padalyta iš } 3\end{array}$ & $\begin{array}{c}\text { Galutinis } \\
\text { procentilis }\end{array}$ \\
\hline 1. & Skuodo r. SVB & 0,45 & 0,150 & 0,00 \\
\hline 2. & Visagino SVB & 0,55 & 0,182 & 0,05 \\
\hline 3. & Akmenès r. SVB & 0,55 & 0,183 & 0,09 \\
\hline 4. & Švenčionių r. SVB & 0,73 & 0,245 & 0,14 \\
\hline 5. & Lazdijų r. SVB & 0,95 & 0,317 & 0,18 \\
\hline 6. & Pakruojo r. SVB & 1,08 & 0,360 & 0,23 \\
\hline 7. & Širvintų r. SVB & 1,14 & 0,380 & 0,27 \\
\hline 8. & Palangos SVB & 1,32 & 0,440 & 0,32 \\
\hline 9. & Šilalès r. SVB & 1,32 & 0,440 & 0,32 \\
\hline 10. & Varènos r. SVB & 1,32 & 0,440 & 0,32 \\
\hline 11. & Druskininkų SVB & 1,41 & 0,470 & 0,45 \\
\hline 12. & Alytaus r. SVB & 1,55 & 0,517 & 0,50 \\
\hline 13. & Biržų r. SVB & 1,59 & 0,530 & 0,55 \\
\hline 14. & Prienų r. SVB & 1,59 & 0,530 & 0,55 \\
\hline 15. & Kupiškio r. SVB & 1,73 & 0,576 & 0,64 \\
\hline 16. & Ignalinos r. SVB & 1,77 & 0,590 & 0,68 \\
\hline 17. & Elektrènų SVB & 1,82 & 0,606 & 0,73 \\
\hline 18. & Anykščiu r. SVB & 1,86 & 0,621 & 0,77 \\
\hline 19. & Pasvalio r. SVB & 1,95 & 0,649 & 0,82 \\
\hline 20. & Jurbarko r. SVB & 2,09 & 0,696 & 0,86 \\
\hline 21. & Joniškio r. SVB & 2,41 & 0,803 & 0,91 \\
\hline 22. & Zarasų r. SVB & 2,49 & 0,830 & 0,95 \\
\hline 23. & Molètų r. SVB & 2,50 & 0,833 & 1,00 \\
\hline & & & & \\
\hline
\end{tabular}


58 lentelè. IV dimensija. 2 grupès biblioteku plètros įvertinimas

\begin{tabular}{|c|c|c|c|c|}
\hline $\begin{array}{l}\text { Eil. } \\
\text { Nr. }\end{array}$ & SVB pavadinimas & Procentilių suma & $\begin{array}{c}\text { Procentilių suma, } \\
\text { padalyta iš } 3\end{array}$ & $\begin{array}{c}\text { Galutinis pro- } \\
\text { centilis }\end{array}$ \\
\hline 1. & Molètų r. SVB & 2,50 & 0,833 & 1,00 \\
\hline 2. & Zarasų r. SVB & 2,49 & 0,830 & 0,95 \\
\hline 3. & Joniškio r. SVB & 2,41 & 0,803 & 0,91 \\
\hline 4. & Jurbarko r. SVB & 2,09 & 0,696 & 0,86 \\
\hline 5. & Pasvalio r. SVB & 1,95 & 0,649 & 0,82 \\
\hline 6. & Anykščių r. SVB & 1,86 & 0,621 & 0,77 \\
\hline 7. & Elektrènų SVB & 1,82 & 0,606 & 0,73 \\
\hline 8. & Ignalinos r. SVB & 1,77 & 0,590 & 0,68 \\
\hline 9. & Kupiškio r. SVB & 1,73 & 0,576 & 0,64 \\
\hline 10. & Prienų r. SVB & 1,59 & 0,530 & 0,55 \\
\hline 11. & Biržų r. SVB & 1,59 & 0,530 & 0,55 \\
\hline 12. & Alytaus r. SVB & 1,55 & 0,517 & 0,50 \\
\hline 13. & Druskininku SVB & 1,41 & 0,469 & 0,45 \\
\hline 14. & Šilalès r. SVB & 1,32 & 0,440 & 0,32 \\
\hline 15. & Varènos r. SVB & 1,32 & 0,440 & 0,32 \\
\hline 16. & Palangos SVB & 1,32 & 0,440 & 0,32 \\
\hline 17. & Širvintų r. SVB & 1,14 & 0,380 & 0,27 \\
\hline 18. & Pakruojo r. SVB & 1,08 & 0,360 & 0,23 \\
\hline 19. & Lazdijų r. SVB & 0,95 & 0,317 & 0,18 \\
\hline 20. & Švenčionių r. SVB & 0,73 & 0,245 & 0,14 \\
\hline 21. & Akmenès r. SVB & 0,55 & 0,183 & 0,09 \\
\hline 22. & Visagino SVB & 0,55 & 0,182 & 0,05 \\
\hline 23. & Skuodo r. SVB & 0,45 & 0,150 & 0,00 \\
\hline
\end{tabular}

3 grupè. I aukščiausią grupę pateko ir po žvaigždę pelnè Telšiu, Plungès, Utenos, Jonavos, Kelmès, Rokiškio rajonų SVB. Geri ịvertinimai ir aukšta Telšių rajono SVB pozicija pagal du rodiklius: 1 darbuotojo mokymams skirtu valandu skaičiu ir nepaprastąias išlaidas 1 gyventojui - procentilis 1,00, o pagal fondo atnaujinimo procentą ( 0,50 procentilio) biblioteka yra grupès viduryje. Vertinant pagal BIX metodiką, Telšių r. SVB yra sudarytos geros sąlygos tolesnei bibliotekų plètrai (59 lentelè). 
I vidurinę grupę pateko ir po pusę žvaigždès gavo Radviliškio, Trakų, Kaišiadorių, Raseinių, Šilutès, Tauragès, Šiaulių rajonų SVB. Radviliškio ir Trakų rajonu SVB surinkus vienodą procentilių sumą, aukštesnëje vietoje atsidūrè Radviliškio rajono $\mathrm{SVB}$, kurios rodiklio fondo atnaujinimo procentas procentilis - 0,89, Trakų rajono SVB - 0,56.

Žemiausioje grupëje liko Ukmergès, Panevěžio, Šalčininku, Kretingos, Vilkaviškio, Šakių rajonų SVB. Pastarosios bibliotekos IV dimensijos rodiklių ịverčiai yra žemiausi: pagal rodikli fondo atnaujinimo procentas (procentilis - 0,06) 94 proc. grupès bibliotekų buvo aukštesnëje pozicijoje negu ši SVB; pagal 1 darbuotojo mokymams skirtu valandu skaičiu (procentilis - 0,11) aukštesnëje pozicijoje 89 proc. grupès biblioteku, o pagal nepaprastasias išlaidas 1 gyventojui (procentilis - 0,17) 83 proc. grupès bibliotekų. Šakių r. SVB nepakankamai investuoja ị naujas paslaugas ir išteklius, tai rodo rezultatai, pasiekti vertinant I (procentilis 0,33 ), II (procentilis $-0,44$ ) ir III dimensijų rodiklius (procentilis - 0,28) (žr. 14, 16, 31, 46, 59, 60, 61 lenteles).

59 lentelè. IV dimensija. 3 grupès biblioteku pletros rodikliu verčiu procentiliais suma

\begin{tabular}{|c|c|c|c|c|c|}
\hline \multirow{2}{*}{$\begin{array}{l}\text { Eil. } \\
\text { Nr. }\end{array}$} & \multirow{2}{*}{ SVB pavadinimas } & \multicolumn{3}{|c|}{ Procentilis } & \multirow{2}{*}{$\begin{array}{l}\text { Bendra pro- } \\
\text { centilių suma }\end{array}$} \\
\hline & & 1 rodiklis & 2 rodilklis & 3 rodiklis & \\
\hline 1. & Jonavos r. SVB & 1,00 & 0,17 & 0,89 & 2,06 \\
\hline 2. & Kaišiadorių r. SVB & 0,72 & 0,28 & 0,72 & 1,72 \\
\hline 3. & Kelmès r. SVB & 0,22 & 0,89 & 0,94 & 2,05 \\
\hline 4. & Kretingos r. SVB & 0,17 & 0,56 & 0,00 & 0,73 \\
\hline 5. & Panevėžio r. SVB & 0,11 & 0,50 & 0,33 & 0,94 \\
\hline 6. & Plungès r. SVB & 0,83 & 0,94 & 0,56 & 2,33 \\
\hline 7. & Radviliškio r. SVB & 0,89 & 0,39 & 0,50 & 1,78 \\
\hline 8. & Raseinių r. SVB & 0,94 & 0,33 & 0,39 & 1,66 \\
\hline 9. & Rokiškio r. SVB & 0,39 & 0,67 & 0,78 & 1,84 \\
\hline 10. & Šakių r. SVB & 0,06 & 0,11 & 0,17 & 0,34 \\
\hline 11. & Šalčininkų r. SVB & 0,28 & 0,22 & 0,28 & 0,78 \\
\hline 12. & Šiaulių r. SVB & 0,00 & 0,61 & 0,61 & 1,22 \\
\hline 13. & Šilutès r. SVB & 0,61 & 0,83 & 0,22 & 1,66 \\
\hline
\end{tabular}




\begin{tabular}{|c|c|c|c|c|c|}
\hline \multirow{2}{*}{$\begin{array}{l}\text { Eil. } \\
\text { Nr. }\end{array}$} & \multirow{2}{*}{ SVB pavadinimas } & \multicolumn{3}{|c|}{ Procentilis } & \multirow{2}{*}{$\begin{array}{l}\text { Bendra pro- } \\
\text { centilių suma }\end{array}$} \\
\hline & & 1 rodiklis & 2 rodilklis & 3 rodiklis & \\
\hline 14. & Tauragès r. SVB & 0,67 & 0,00 & 0,83 & 1,50 \\
\hline 15. & Telšių r. SVB & 0,50 & 1,00 & 1,00 & 2,50 \\
\hline 16. & Trakų r. SVB & 0,56 & 0,78 & 0,44 & 1,78 \\
\hline 17. & Ukmergès r. SVB & 0,44 & 0,44 & 0,11 & 0,99 \\
\hline 18. & Utenos r. SVB & 0,78 & 0,72 & 0,67 & 2,17 \\
\hline 19. & Vilkaviškio r. SVB & 0,33 & 0,06 & 0,06 & 0,45 \\
\hline
\end{tabular}

1 rodiklis - fondo atnaujinimo procentas;

2 rodiklis - 1 darbuotojo mokymams skirtu valandu skaičius;

3 rodiklis - nepaprastosios išlaidos 1 gyventojui.

60 lentelè. IV dimensija. 3 grupes biblioteku bendrasis pletros rodikliu verčiu procentilis

\begin{tabular}{|c|c|c|c|c|}
\hline $\begin{array}{l}\text { Eil. } \\
\text { Nr. }\end{array}$ & SVB pavadinimas & $\begin{array}{l}\text { Procentilių } \\
\text { suma }\end{array}$ & $\begin{array}{c}\text { Procentilių suma, } \\
\text { padalyta iš } 3\end{array}$ & $\begin{array}{l}\text { Galutinis } \\
\text { procentilis }\end{array}$ \\
\hline 1. & Šakių r. SVB & 0,34 & 0,113 & 0,00 \\
\hline 2. & Vilkaviškio r. SVB & 0,45 & 0,150 & 0,06 \\
\hline 3. & Kretingos r. SVB & 0,73 & 0,243 & 0,11 \\
\hline 4. & Šalčininkų r. SVB & 0,78 & 0,260 & 0,17 \\
\hline 5. & Panevėžio r. SVB & 0,94 & 0,313 & 0,22 \\
\hline 6. & Ukmergès r. SVB & 0,99 & 0,330 & 0,28 \\
\hline 7. & Šiaulių r. SVB & 1,22 & 0,407 & 0,33 \\
\hline 8. & Tauragès r. SVB & 1,50 & 0,500 & 0,39 \\
\hline 9. & Šilutès r. SVB & 1,66 & 0,553 & 0,44 \\
\hline 10. & Raseinių r. SVB & 1,66 & 0,555 & 0,50 \\
\hline 11. & Kaišiadorių r. SVB & 1,72 & 0,573 & 0,56 \\
\hline 12. & Radviliškio r. SVB & 1,78 & 0,593 & 0,61 \\
\hline 13. & Trakų r. SVB & 1,78 & 0,593 & 0,61 \\
\hline 14. & Rokiškio r. SVB & 1,84 & 0,613 & 0,72 \\
\hline 15. & Kelmès r. SVB & 2,05 & 0,683 & 0,78 \\
\hline 16. & Jonavos r. SVB & 2,06 & 0,687 & 0,83 \\
\hline 17. & Utenos r. SVB & 2,17 & 0,723 & 0,89 \\
\hline 18. & Plungès r. SVB & 2,33 & 0,778 & 0,94 \\
\hline 19. & Telšių r. SVB & 2,50 & 0,833 & 1,00 \\
\hline
\end{tabular}


61 lentelè. IV dimensija. 3 grupés biblioteku pletros iqvertinimas

\begin{tabular}{|c|c|c|c|c|}
\hline $\begin{array}{l}\text { Eil. } \\
\text { Nr. }\end{array}$ & SVB pavadinimas & Pprocentilių suma & $\begin{array}{l}\text { Procentilių } \\
\text { suma, padalyta } \\
\text { iš } 3\end{array}$ & $\begin{array}{l}\text { Galutinis } \\
\text { procentilis }\end{array}$ \\
\hline 1. & Telšių r. SVB & 2,50 & 0,833 & 1,00 \\
\hline 2. & Plungès r. SVB & 2,33 & 0,778 & 0,94 \\
\hline 3. & Utenos r. SVB & 2,17 & 0,723 & 0,89 \\
\hline 4. & Jonavos r. SVB & 2,06 & 0,687 & 0,83 \\
\hline 5. & Kelmès r. SVB & 2,05 & 0,683 & 0,78 \\
\hline 6. & Rokiškio r. SVB & 1,84 & 0,613 & 0,72 \\
\hline 7. & Radviliškio r. SVB & 1,78 & 0,593 & 0,61 \\
\hline 8. & Trakų r. SVB & 1,78 & 0,593 & 0,61 \\
\hline 9. & Kaišiadorių r. SVB & 1,72 & 0,573 & 0,56 \\
\hline 10. & Raseinių r. SVB & 1,66 & 0,555 & 0,50 \\
\hline 11. & Šilutės r. SVB & 1,66 & 0,553 & 0,44 \\
\hline 12. & Tauragès r. SVB & 1,50 & 0,500 & 0,39 \\
\hline 13. & Šiaulių r. SVB & 1,22 & 0,407 & 0,33 \\
\hline 14. & Ukmergès r. SVB & 0,99 & 0,330 & 0,28 \\
\hline 15. & Panevėžio r. SVB & 0,94 & 0,313 & 0,22 \\
\hline 16. & Šalčininkų r. SVB & 0,78 & 0,260 & 0,17 \\
\hline 17. & Kretingos r. SVB & 0,73 & 0,243 & 0,11 \\
\hline 18. & Vilkaviškio r. SVB & 0,45 & 0,150 & 0,06 \\
\hline 19. & Šakių r. SVB & 0,34 & 0,113 & 0,00 \\
\hline
\end{tabular}

4 grupè. İ aukščiausią grupę pateko Marijampolès, Kauno rajono ir Panevėžio miesto SVB (žr. 64 lentelę).

Marijampolès SVB rodiklių vertès yra tokios: fondo atnaujinimo procento ir nepaprastuju išlaidu 1 gyventojui procentiliai - 1,00, o 1 darbuotojo mokymams skirtu valandu skaiciaus procentilis - 0,43. Galima teigti, kad biblioteka pakankamai investuoja ị išteklius, infrastruktūrą ir naujas paslaugas (su I ir II dimensijų rodikliais pateko ị auksinę grupę), turi gerus gebëjimus gauti pakankamą finansavimą plètrai.

Kauno rajono SVB fondo atnaujinimo procento procentilis - 0,29, kitų rodiklių procentiliai: nepaprastuju išlaidu 1 gyventojui-0,71; 1 darbuo- 
tojo mokymams skirtu valandu skaičiaus procentilis - 1,00. Šios bibliotekos pagrindinè problema - fondo atnaujinimas ir fondo kokybè, nes rodikliu dokumentu išduočiu (fiz. vnt.) skaičius 1 gyventojui (II dimensijos 1 rodiklis) ir fondo apyvarta (II dimensijos 4 rodiklis) procentiliai - 0,14, t. y. 86 proc. šios grupès bibliotekų pagal šiuos rodiklius užima aukštesnę vietą (žr. 17, 32, 62, 64 lenteles).

I vidurinę grupę pateko ir pusę žvaigždès pelnè Kèdainių rajono ir Alytaus miesto SVB. Kèdainių r. SVB fondo atnaujinimo procento procentilis - 0,71; nepaprastuju išlaidu 1 gyventojui procentilis - 0,86, o 1 darbuotojo mokymams skirtu valandu skaičiaus procentilis - 0,14. Ši SVB tiek pagal I, tiek pagal II dimensijos rodiklius pateko į auksinę grupę (procentiliai - 1,00), todèl galima teigti, kad biblioteka pakankamai investuoja i išteklius ir paslaugas, bet darbuotojų profesionalumo ugdymas turètų būti vienas svarbiausių ateities uždavinių.

İ žemiausiąją grupę pateko Klaipedos, Vilniaus ir Mažeikių rajonu SVB. Mažeikių rajono SVB rodikliu fondo atnaujinimo procentas ir nepaprastosias išlaidos 1 gyventojui procentiliai - 0,00, o 1 darbuotojo mokymams skirtu valandu skaičius procentilis $-0,57$. Atsižvelgiant $\mathfrak{i}$ tai, kad Mažeikių r. SVB ir kitose dimensijose nepasiekè gerų rezultatų (I dimensijoje pateko ị vidurinę grupëje (procentilis - 0,43), o su II, III ir IV dimensijų rodikliais yra žemiausioje grupejje, ši SVB turi pakankamai problemų: tai ir fondo atnaujinimas, ir jo kokybè, naujų paslaugu kūrimas, lèšų stoka tolesnei bibliotekos plètrai. Vilniaus rajono SVB I, II ir III dimensijų požiūriu pateko ị žemiausią grupę, o IV dimensijos rodiklių rezultatai tokie: rodikliu fondo atnaujinimo procentas ir nepaprastosias išlaidos 1 gyventojui procentiliai - 0,43; 1 darbuotojo mokymams skirtu valandu skaičiaus procentilis - 0,00. Šio tyrimo rezultatai turetu paskatinti Vilniaus r. SVB daugiau investuoti ì darbuotojų mokymą, sudaryti darbuotojams sąlygas ugdyti profesinius gebejjimus (žr. 19, 34, 49, 62, 63, 64 lenteles). 
62 lentelè. IV dimensija. 4 grupès biblioteku pletros rodikliu verčiu procentiliais suma

\begin{tabular}{|c|l|c|c|c|c|}
\hline \multirow{2}{*}{ Eil. } & \multirow{2}{*}{ SVB pavadinimas } & \multicolumn{3}{|c|}{ Procentilis } & Bendra pro- \\
\cline { 3 - 6 } & & 1 rodiklis & 2 rodiklis & 3 rodiklis & centilių suma \\
\hline 1. & Alytaus m. SVB & 0,57 & 0,86 & 0,14 & 1,57 \\
\hline 2. & Kauno r. SVB & 0,29 & 1,00 & 0,71 & 2,00 \\
\hline 3. & Kèdainių r. SVB & 0,71 & 0,14 & 0,86 & 1,71 \\
\hline 4. & Klaipèdos r. SVB & 0,14 & 0,29 & 0,57 & 1,00 \\
\hline 5. & Marijampoles SVB & 1,00 & 0,43 & 1,00 & 2,43 \\
\hline 6. & Mažeikiu r. SVB & 0,00 & 0,57 & 0,00 & 0,57 \\
\hline 7. & Panevěżio m. SVB & 0,86 & 0,71 & 0,29 & 1,86 \\
\hline 8. & Vilniaus r. SVB & 0,43 & 0,00 & 0,43 & 0,86 \\
\hline
\end{tabular}

1 rodiklis - fondo atnaujinimo procentas;

2 rodiklis - 1 darbuotojo mokymams skirtu valandu skaičius;

3 rodiklis - nepaprastosios išlaidos 1 gyventojui.

63 lentelè. IV dimensija. 4 grupès biblioteku bendrasis pletros rodikliu verčiu procentilis

\begin{tabular}{|c|l|c|c|c|}
$\begin{array}{c}\text { Eil. } \\
\text { Nr. }\end{array}$ & \multicolumn{1}{|c|}{ SVB pavadinimas } & $\begin{array}{c}\text { Procentilių } \\
\text { suma }\end{array}$ & $\begin{array}{c}\text { Procentilių suma, } \\
\text { padalyta iš 3 }\end{array}$ & $\begin{array}{c}\text { Galutinis } \\
\text { procentilis }\end{array}$ \\
\hline 1. & Mažeikių r. SVB & 0,57 & 0,190 & 0,00 \\
\hline 2. & Vilniaus r. SVB & 0,86 & 0,287 & 0,14 \\
\hline 3. & Klaipèdos r. SVB & 1,00 & 0,333 & 0,29 \\
\hline 4. & Alytaus m. SVB & 1,57 & 0,523 & 0,43 \\
\hline 5. & Kèdainių r. SVB & 1,71 & 0,570 & 0,57 \\
\hline 6. & Panevěžio m. SVB & 1,86 & 0,620 & 0,71 \\
\hline 7. & Kauno r. SVB & 2,00 & 0,667 & 0,86 \\
\hline 8. & Marijampolès SVB & 2,43 & 0,810 & 1,00 \\
\hline
\end{tabular}

64 lentelè. IV dimensija. 4 grupes biblioteku pletros įvertinimas

\begin{tabular}{|c|c|c|c|c|}
\hline $\begin{array}{l}\text { Eil. } \\
\text { Nr. }\end{array}$ & SVB pavadinimas & $\begin{array}{l}\text { Procentilių } \\
\text { suma }\end{array}$ & $\begin{array}{c}\text { Procentilių suma, } \\
\text { padalyta iš } 3\end{array}$ & $\begin{array}{l}\text { Galutinis pro- } \\
\text { centilis }\end{array}$ \\
\hline 1. & Marijampolès SVB & 2,43 & 0,810 & 1,00 \\
\hline 2. & Kauno r. SVB & 2,00 & 0,667 & 0,86 \\
\hline 3. & Panevėžio $\mathrm{m}$. SVB & 1,86 & 0,620 & 0,71 \\
\hline 4. & Kèdainių r. SVB & 1,71 & 0,570 & 0,57 \\
\hline 5. & Alytaus m. SVB & 1,57 & 0,523 & 0,43 \\
\hline 6. & Klaipèdos r. SVB & 1,00 & 0,333 & 0,29 \\
\hline 7. & Vilniaus r. SVB & 0,86 & 0,287 & 0,14 \\
\hline 8. & Mažeikių r. SVB & 0,57 & 0,190 & 0,00 \\
\hline
\end{tabular}


5 grupè. I aukščiausią̧ą grupę pateko ir žvaigždę gavo Vilniaus ir Kauno miestų SVB (̌̌r. 67 lentelę). Šioje dimensijoje Vilniaus miesto SVB rodiklių vertès: fondo atnaujinimo procento ir nepaprastuju išlaidų 1 gyventojui procentiliai - 1,00, o 1 darbuotojo mokymams skirtu valandu skaičiu procentilis - 0,00. Vilniaus $\mathrm{m}$. SVB 1 darbuotojo mokymams $2013 \mathrm{~m}$. skirta 3,54 val., o Kauno m. SVB 1 darbuotojui per metus mokymams skirta 22,82 val., arba 6,4 kartus daugiau negu darbuotojui, dirbančiam Vilniaus $\mathrm{m}$. CB ir jos padaliniuose. Vilniaus $\mathrm{m}$. SVB pagal I ir II dimensijų rodiklius pateko į žemiausią grupę, o III ir IV dimensijose - į auksinę grupę. Vilniaus $\mathrm{m}$. SVB turètų daugiau investuoti ị išteklius ir infrastruktūrą, naujas paslaugas, nes naudojimasis jos teikiamomis paslaugomis yra menkas, tačiau džiugina faktas, kad fondo atnaujinimo procentas siekia 8,18 proc., arba gauta 43989 fiz. vnt. naujų dokumentu per metus.

Vilniaus ir Kauno miestų SVB surinkus vienodą procentilių sumą, aukštesnè pozicija yra Vilniaus m. SVB, kurios rodiklio fondo atnaujinimo procentas vertès procentilis yra 1,00, Kauno m. SVB - 0,67.

I vidurinę grupę pateko ir pusę žvaigždès pelnẻ Klaipèdos m. SVB. Žemiausioje grupëje liko Šiaulių m. SVB. Pastarosios bibliotekos rodikliu fondo atnaujinimo procentas ir nepaprastosias išlaidos 1 gyventojui procentiliai yra žemiausi - 0,00 (žr. 22, 37, 52, 65, 66, 67 lenteles).

65 lentelè. IV dimensija. 5 grupès biblioteku pletros rodikliu verčiu procentiliais suma

\begin{tabular}{|c|l|c|c|c|c|}
\hline \multirow{2}{*}{ Eil. } & \multirow{2}{*}{ SVB pavadinimas } & \multicolumn{3}{|c|}{ Procentilis } & Bendra pro- \\
\cline { 3 - 6 } & & 1 rodiklis & 2 rodilklis & 3 rodiklis & $\begin{array}{c}\text { Bentilių suma } \\
\text { Nr. }\end{array}$ \\
\hline 1. & Kauno m. SVB & 0,67 & 1,00 & 0,33 & 2,00 \\
\hline 2. & Klaipèdos m. SVB & 0,33 & 0,33 & 0,67 & 1,33 \\
\hline 3. & Šiaulių m. SVB & 0,00 & 0,67 & 0,00 & 0,67 \\
\hline 4. & Vilniaus m. SVB & 1,00 & 0,00 & 1,00 & 2,00 \\
\hline
\end{tabular}

1 rodiklis - fondo atnaujinimo procentas;

2 rodiklis - 1 darbuotojo mokymams skirtu valandu skaičius;

3 rodiklis - nepaprastosios išlaidos 1 gyventojui. 
66 lentelè. IV dimensija. 5 grupes biblioteku bendrasis pletros rodikliu verčiu procentilis

\begin{tabular}{|c|l|c|c|c|}
\hline Eil. & \multicolumn{1}{|c|}{ SVB pavadinimas } & $\begin{array}{c}\text { Procentilių } \\
\text { suma }\end{array}$ & $\begin{array}{c}\text { Procentilių suma, } \\
\text { padalyta iš 3 }\end{array}$ & $\begin{array}{c}\text { Galutinis } \\
\text { procentillis }\end{array}$ \\
\hline 1. & Šiaulių m. SVB & 0,67 & 0,223 & 0,00 \\
\hline 2. & Klaipédos m.SVB & 1,33 & 0,443 & 0,33 \\
\hline 3. & Kauno m. SVB & 2,00 & 0,667 & 0,67 \\
\hline 4. & Vilniaus m. SVB & 2,00 & 0,667 & 0,67 \\
\hline
\end{tabular}

67 lentelè. IV dimensija. 5 grupes biblioteku plètros įvertinimas

\begin{tabular}{|c|c|c|c|c|}
\hline $\begin{array}{l}\text { Eil. } \\
\text { Nr. }\end{array}$ & SVB pavadinimas & $\begin{array}{l}\text { Procentilių } \\
\text { suma }\end{array}$ & $\begin{array}{l}\text { Procentilių suma, } \\
\text { padalyta iš } 3\end{array}$ & $\begin{array}{l}\text { Galutinis pro- } \\
\text { centilis }\end{array}$ \\
\hline 1. & Vilniaus $\mathrm{m}$. SVB & 2,00 & 0,67 & 0,67 \\
\hline 2. & Kauno m. SVB & 2,00 & 0,67 & 0,67 \\
\hline 3. & Klaipedos m. SVB & 1,33 & 0,44 & 0,33 \\
\hline 4. & Šiaulių m. SVB & 0,67 & 0,22 & 0,00 \\
\hline
\end{tabular}

\subsubsection{Galutinis SVB vertinimas}

Galutiniame vertinimo etape bibliotekos rikiuojamos abėcèlès seka ir pagal keturių dimensijų rezultatus pažymimos ta spalva, ị kurią vertinimo grupę pateko (auksiné, šviesiai mèlyna ar tamsiai mèlyna), taip pat susumuojamos skirtos žvaigždès (dvi po pusę žvaigždès skaičiuojama kaip viena) (žr. 68 lentelę). 1-5 prieduose pateikiamos kiekvienos bibliotekų grupès I-IV dimensijų rodiklių vertès ir kiekvienos bibliotekų grupès rodiklių minimumas, maksimumas bei šalies vidurkis.

1 grupé (6 SVB). Birštono SVB surinko 3,5 žvaigždès: I dimensijoje - Istekliai ir infrastruktūra (procentilis - 1,00), II dimensijoje Naudojimasis biblioteka (procentilis - 1,00) ir III dimensijoje - Našumas (procentilis - 0,80) pateko ị auksinę grupę, o IV dimensijoje - Pletra pelnè pusę žvaigždès (procentilis - 0,60).

Pagègių SVB pelnè 2,5 žvaigždès: ị aukščiausią grupę pateko I dimensijoje - Ištekliai ir infrastruktūra (procentilis - 0,80) ir III dimensijoje - 
Našumas (procentilis - 1,00), II dimensijoje - Naudojimasis biblioteka buvo vidurinëje grupëje ir pelnè pusę žvaigždès (procentilis - 0,60).

Kazlų Rūdos SVB surinko 2 žvaigždes. Aukščiausiai biblioteka ivertinta IV dimensijoje - Pletra (0,80 procentilio) ir pelnè žvaigždę, o II dimensijoje - Naudojimasis biblioteka ir III dimensijoje - Našumas pateko i vidurinę grupę ir gavo po pusę žvaigždès.

Rietavo SVB surinko 1,5 žvaigždès: I dimensijoje - Ištekliai ir infrastruktūra ir II dimensijose - Naudojimasis biblioteka buvo žemiausioje grupeje, III dimensijoje - Našumas (0,40 procentilio) pelnè pusę žvaigždès, o IV dimensijoje - Plètra pateko ị aukščiausią grupę (procentilis - 1,00).

Po 1 žvaigždę pelnè Neringos ir Kalvarijos SVB: Neringos SVB I ir II dimensijose pateko į vidurinę grupę, o Kalvarijos SVB - vidutiniokè pagal I ir IV dimensijų rodiklius; taigi abi gavo po pusę žvaigždès, jų procentiliai svyravo nuo 0,00 iki 0,60 procentilio.

2 grupè (pati didžiausia - 23 SVB). Maksimalų žvaigždžių skaičių (4) surinko Ignalinos ir Pasvalio rajonų SVB. Ignalinos r. SVB pagal visų dimensijų rodiklius pateko į aukščiausią grupę ir ịvertinta 4 žvaigždemis, bet nè vienoje dimensijų negavo aukščiausio ịvertinimo (1,00 procentilio); ji buvo vertinama stabiliai - 0,68-0,82 procentilio.

Pasvalio r. SVB II dimensijoje - Naudojimasis biblioteka gavo aukščiausią îvertinimą (procentilis - 1,00), o kitose trijose dimensijose - Istekliai ir infrastruktūra, Našumas ir Plètra buvo įvertinta atitinkamai 0,68, 0,95, 0,82 procentilio.

Žemesni ịvertinimą - po 3 žvaigždes gavo Alytaus, Anykščiu, Joniškio, Jurbarko, Molètų, Zarasų rajonų SVB.

Joniškio rajono SVB trijose dimensijose - Naudojimasis biblioteka, Našumas ir Pletra pateko ị auksinę grupę, nors nè vienoje negavo aukščiausio ịvertinimo (procentiliai svyravo nuo 0,68 iki 0,91), žemiausi jos I dimensijos - Istekliai ir infrastruktūra rodikliai (0,32 procentilio).

Zarasų rajono SVB pagal trijų dimensijų rodiklius: I - Ištekliai ir infrastruktūra (procentilis - 1,00), II - Naudojimasis biblioteka (procen- 
tilis - 0,86) ir IV - Plètra (procentilis - 0,95) pateko ị aukščiausią grupę, tik III dimensijos - Našumas rezultatai yra blogiausi.

Alytaus, Anykščių, Jurbarko, Molètų rajonų SVB po du kartus pateko ị auksinę grupę. Stabiliausiai iš jų pasirodè Alytaus r. SVB, kurios procentiliai svyravo nuo 0,50 (Plètra) iki 1,00 (Našumas).

2,5 žvaigždès surinko Varènos rajono SVB, po 2 žvaigždes - Skuodo ir Širvintų rajonų SVB.

Po 1,5 žvaigždès gavo Pakruojo, Biržų, Kupiškio rajonų, Druskininku, Palangos ir Elektrènų SVB.

Po 1 žvaigždę surinko Lazdijų, Švenčioniu, Prienų rajonų SVB.

Trys šios grupès SVB - Akmenès, Šilalès rajonų ir Visagino SVB nepelne žvaigždžiu.

Akmenès rajono SVB galutiniai rezultatai yra tokie: pagal I dimensijos rodiklius gavo 0,14 procentilio, 86 proc. bibliotekų rezultatai yra geresni; pagal II ir III dimensiju rodiklius - 0,05 procentilio, 95 proc. biblioteku vieta yra aukštesné; pagal IV dimensijos - 0,09 procentilio, 91 proc. bibliotekų rodikliai yra geresni. Panaši ir Visagino SVB padètis: I, II ir III dimensiju rodiklių procentiliai - 0,00, o IV dimensijos procentilis 0,05. Pastarojoje dimensijoje (Pletra) gauti žemi ịvertinimai tik patvirtina faktą, kad Akmenės rajono ir Visagino SVB turi mažą plètros potencialą. Neturèdamos pakankamai lèšu, SVB negali pagerinti bibliotekų infrastruktūros, sudaryti darbuotojams sąlygų vykti ị mokymus. Negalintys tobulinti gebejjimų darbuotojai sunkiau prisitaiko prie nuolat atsinaujinančių informacinių technologijų, negali pasiūlyti bendruomenei naujų paslaugų.

3 grupè (19 SVB). Rokiškio rajono SVB pagal visų dimensijų rodiklius pateko ị aukščiausią grupę ir ịvertinta maksimaliai -4 žvaigždemis. Trijose dimensijose - Istekliai ir infrastruktūra, Naudojimasis biblioteka, Našumas Rokiškio rajono SVB gavo aukščiausią ịvertinimą (procentilis 1,00), IV dimensijoje (Pletra) surinko 0,72 procentilio. Rokiškio r. SVB rezultatai yra stabilūs, net trijų dimensijų požiūriu ši įstaiga savo grupẻje užèmė aukščiausias vietas. 
3,5 žvaigždes surinko Utenos rajono SVB. Tik III dimensijoje (Našumas) gautas rezultatas ( 0,50 procentilio) neleido bibliotekai iškovoti maksimalaus žvaigždžiu skaičiaus: mažiausiai įvertintas šios dimensijos rodiklis Darbuotoju darbo valandu ir valandu, per kurias biblioteka atvira lankytojams, santykis - 0,11 procentilio.

3 žvaigždès atiteko Kelmès, Radviliškio, Šilutès, Jonavos rajonų SVB. Radviliškio r. SVB pasiekè gerų rezultatų: I dimensijoje - Istekliai ir infrastruktūra $(0,80$ procentilio) ir II dimensijoje - Naudojimasis biblioteka (0,78 procentilio) pateko ị auksinę grupę, o III ir IV dimensijose pateko ị vidurinę grupę ir pelnè po pusę žvaigždès (procentilis - 0,61).

Po 2,5 žvaigždès yra gavusios Panevėžio, Kaišiadorių ir Telš̌ių rajonų SVB.

2 žvaigždes pelnè Šalčininkų, Ukmergès, Trakų, Plungès rajonų SVB.

$1 \check{z}$ vaigždę gavo Raseinių, Tauragès ir Šakių rajonų SVB.

Tik 0,5 žvaigždes teko Vilkaviškio ir Šiaulių rajonų SVB.

Kretingos rajono SVB nepelne žvaigždžiu. Šios SVB galutiniai rezultatai yra tokie: I, III, IV dimensijos rodikliai - 0,11 procentilio; 89 proc. šios grupès SVB pozicija yra aukštesné; II dimensijos - 0,28 procentilio, 72 proc. SVB užèmè geresnę vietą.

4 grupè (8 SVB). Po 3,5 žvaigždes surinko Kèdainių rajono ir Marijampolès SVB. Kèdainių r. SVB I dimensijoje - Istekliai ir infrastruktūra, II dimensijoje - Naudojimasis biblioteka, III dimensijoje - Našumas gavo aukščiausią įvertinimą (procentilis - 1,00), IV dimensijoje - Pletra - 0,57 procentilio. Marijampolès SVB pagal I, II, IV dimensijų rodiklius pateko i auksinę grupę ir pelnẻ po žvaigždę, III dimensijoje pateko i̇ vidurinę grupę.

2,5 žvaigždes gavo Panevėžio miesto SVB ir Klaipedos rajono SVB. Panevežio $\mathrm{m}$. SVB I dimensijoje gavo žemiausią įvertinimą (procentilis $0,00)$, su II dimensijos rodikliais pateko ị vidurinę grupę, o štai, vertinant III ir IV dimensiju požiūriu, pateko ị auksinę grupę. 
2 žvaigždes gavo Kauno rajono SVB (IV dimensijoje pateko ị auksinę grupę).

1,5 žvaigždès atiteko Alytaus miesto SVB: I dimensijoje - Istekliai ir infrastruktūra (procentilis - 0,14) ir II dimensijoje - Naudojimasis biblioteka (procentilis - 0,29) pateko į žemiausią grupę, pagal III dimensijos Našumas (procentilis - 0,71 ) rodiklius gavo žvaigždę, o pagal IV dimensijos - Pletra rodiklius biblioteka ịvertinta puse žvaigždès ( 0,43 procentilio).

0,5 žvaigždès atiteko Mažeikių rajono SVB: pagal IV dimensijos (Pletra) rodiklius procentilis 0,00 , o pagal I dimensijos (Istekliai ir infrastruktūra) $-0,43$.

Vilniaus rajono SVB žvaigždžiu nepelnè. II dimensijoje - Naudojimasis biblioteka ir III dimensijoje - Našumas gavo žemiausią ịvertinimą 0,00, I dimensijoje - Ištekliai ir infrastruktūra procentilis buvo 0,29, o IV dimensijoje - Pletra SVB įvertinta 0,14 procentilio

5 grupè (4 VB). Klaipèdos miesto SVB gavo 3,5 žvaigždès. Vertinant I, II, III dimensijų rodiklius, ši SVB pateko ị auksinę grupę ir pelnẻ po žvaigždę, tik IV dimensijoje (Plètra) SVB buvo įvertinta 0,33 procentilio (puse žvaigždès).

3 žvaigždes gavo Kauno miesto SVB. II ir IV dimensijose ji pateko $\mathfrak{i}$ auksinę grupę.

$2 \check{z}$ vaigždes iškovojo Vilniaus m. SVB. Pagal I ir II dimensijų rodiklius ji pateko ị žemiausią gupę (procentiliai - 0,00), o štai III ir IV dimensijose pateko ị auksinę grupę (procentiliai - 1,00).

1,5 žvaigždès pelnė Šiaulių m. SVB, kuri III ir IV dimensijose buvo ivertinta žemiausiai (procentiliai - 0,00), o I dimensijoje (Istekliai ir infrastruktūra) pateko ị auksinę grupę (procentilis - 1,00). 
68 lentele. Galutinis SVB įvertinimas

\begin{tabular}{|c|c|c|c|c|c|c|c|c|}
\hline \multirow[b]{2}{*}{$\begin{array}{l}\text { Eil. } \\
\text { nr. }\end{array}$} & \multirow[b]{2}{*}{$\begin{array}{c}\text { SVB } \\
\text { pavadinimas }\end{array}$} & \multirow[b]{2}{*}{ Grupè } & \multicolumn{4}{|c|}{ DIMENSIJOS } & \multirow[b]{2}{*}{$\begin{array}{l}\text { Tarpinis } \\
\text { BIX in- } \\
\text { deksas }\end{array}$} & \multirow[b]{2}{*}{$\begin{array}{l}\text { Galutinis } \\
\text { BIX in- } \\
\text { deksas }\end{array}$} \\
\hline & & & $\begin{array}{l}\text { Ištekliai } \\
\text { ir infra- } \\
\text { struktūra }\end{array}$ & $\begin{array}{c}\text { Naudo- } \\
\text { jimasis } \\
\text { bibliote- } \\
\text { ka }\end{array}$ & Našumas & Plètra & & \\
\hline 1. & Akmenès r. SVB & 2 & & & & & - & - \\
\hline 2. & Alytaus r. SVB & 2 & & & & & 大ᄎt人从 & 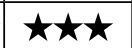 \\
\hline 3. & Alytaus m. SVB & 4 & & & & & $\star x$ & $\star x$ \\
\hline 4. & Anykščių r. SVB & 2 & & & & & 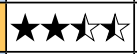 & 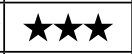 \\
\hline 5. & Birštono SVB & 1 & & & & & $\star \star \star \star \star \rtimes$ & 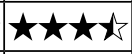 \\
\hline 6. & Biržų r. SVB & 2 & & & & & t心t & $\star x$ \\
\hline 7. & Druskininkų SVB & 2 & & & & & $\star x$ & $\star x$ \\
\hline 8. & Elektrėnų SVB & 2 & & & & & $\star x$ & $\star x$ \\
\hline 9. & Ignalinos r. SVB & 2 & & & & & 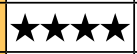 & 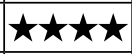 \\
\hline 10. & Jonavos r. SVB & 3 & & & & & 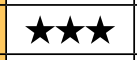 & 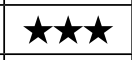 \\
\hline 11. & Joniškio r. SVB & 2 & & & & & 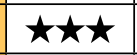 & 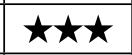 \\
\hline 12. & Jurbarko r. SVB & 2 & & & & & $\star \star x t \leq t$ & 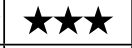 \\
\hline 13. & Kaišiadorių r. SVB & 3 & & & & & 大级认 & $\star \star \star x$ \\
\hline 14. & Kalvarijos r. SVB & 1 & & & & & $x$ & $\star$ \\
\hline 15. & Kauno m. SVB & 5 & & & & & $\star \star \star \star x \downarrow$ & 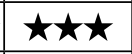 \\
\hline 16. & Kauno r. SVB & 4 & & & & & 大t女t & $\star \star \star$ \\
\hline 17. & Kazlų Rūdos SVB & 1 & & & & & $\star x<x$ & $\star \star$ \\
\hline 18. & Kelmès r. SVB & 3 & & & & & $\star \star \star \star x \downarrow$ & $\star \star \star \star$ \\
\hline 19. & Kèdainių r. SVB & 4 & & & & & 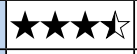 & $\star \star \star \star \star \star x$ \\
\hline 20. & Klaipèdos m. SVB & 5 & & & & & $\star \star \star \star \star \rtimes$ & $\star \star \star \star \star x$ \\
\hline 21. & Klaipèdos r. SVB & 4 & & & & & $\star \star \star x<$ & $\star \star \star x<2$ \\
\hline 22. & Kretingos r. SVB & 3 & & & & & - & - \\
\hline 23. & Kupiškio r. SVB & 2 & & & & & $x+x$ & $\star x$ \\
\hline 24. & Lazdijų r. SVB & 2 & & & & & $\star$ & $\star$ \\
\hline 25. & \begin{tabular}{|l|} 
Marijampolès \\
SVB
\end{tabular} & 4 & & & & & 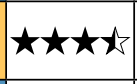 & 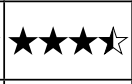 \\
\hline 26. & Mažeikių r. SVB & 4 & & & & & $x$ & $x$ \\
\hline 27. & Molètų r. SVB & 2 & & & & & 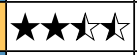 & $\star \star \star \star$ \\
\hline 28. & Neringos SVB & 1 & & & & & t心 & $\star$ \\
\hline 29. & Pagėgių SVB & 1 & & & & & $\star \star \star x t$ & $\star \star \star x$ \\
\hline 30. & Pakruojo r. SVB & 2 & & & & & $\star x$ & $\star x$ \\
\hline 31. & Palangos SVB & 2 & & & & & 颀化 & $\star x$ \\
\hline
\end{tabular}




\begin{tabular}{|c|c|c|c|c|c|c|c|c|}
\hline \multirow[b]{2}{*}{\begin{tabular}{c|} 
Eil. \\
nr.
\end{tabular}} & \multirow[b]{2}{*}{$\begin{array}{c}\text { SVB } \\
\text { pavadinimas }\end{array}$} & \multirow[b]{2}{*}{ Grupè } & \multicolumn{4}{|c|}{ DIMENSIJOS } & \multirow[b]{2}{*}{$\begin{array}{l}\text { Tarpinis } \\
\text { BLX in- } \\
\text { deksas }\end{array}$} & \multirow[b]{2}{*}{$\begin{array}{l}\text { Galutinis } \\
\text { BIX in- } \\
\text { deksas }\end{array}$} \\
\hline & & & $\begin{array}{l}\text { Ištekliai } \\
\text { ir infra- } \\
\text { struktūra }\end{array}$ & $\begin{array}{c}\text { Naudo- } \\
\text { jimasis } \\
\text { bibliote- } \\
\text { ka }\end{array}$ & Našumas & Plètra & & \\
\hline 32. & \begin{tabular}{|l} 
Panevěžio m. \\
SVB
\end{tabular} & 4 & & & & & $\star \star \star x$ & $\star \star \star x$ \\
\hline 33. & Panevė̌̌io r. SVB & 3 & & & & & $\star \star \star x t$ & $\star \star \star x$ \\
\hline 34. & Pasvalio r. SVB & 2 & & & & & 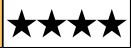 & 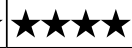 \\
\hline 35. & Plungès r. SVB & 3 & & & & & $\star \star \star$ & $\star \star$ \\
\hline 36. & Prienų r. SVB & 2 & & & & & $x$ & $\star$ \\
\hline 37. & \begin{tabular}{|l|} 
Radviliškio r. \\
SVB \\
\end{tabular} & 3 & & & & & 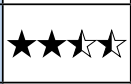 & $\star \star \star \star$ \\
\hline 38. & Raseinių r. SVB & 3 & & & & & $x$ & $\star$ \\
\hline 39. & Rietavo SVB & 1 & & & & & $\star x$ & $\star x$ \\
\hline 40. & Rokiškio r. SVB & 3 & & & & & 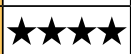 & 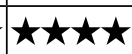 \\
\hline 41. & Skuodo r. SVB & 2 & & & & & txts & $\star \star \star$ \\
\hline 42. & Šakių r. SVB & 3 & & & & & $x$ & $\star$ \\
\hline 43. & Šalčininkų r. SVB & 3 & & & & & $\star x x t$ & $\star \star \star$ \\
\hline 44. & Šiaulių m. SVB & 5 & & & & & $\star x$ & $\star x$ \\
\hline 45. & Šiaulių r. SVB & 3 & & & & & t & 女 \\
\hline 46. & Šilalès r. SVB & 2 & & & & & - & - \\
\hline 47. & Šilutès r. SVB & 3 & & & & & ᄎᄎt女t & $\star \star \star \star$ \\
\hline 48. & Širvintų r. SVB & 2 & & & & & $\star \star \star$ & $\star \star \star$ \\
\hline 49. & Švenčionių r. SVB & 2 & & & & & $\star$ & $\star$ \\
\hline 50. & Tauragès r. SVB & 3 & & & & & $x$ & $\star$ \\
\hline 51. & Telšių r. SVB & 3 & & & & & 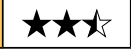 & $\star \star \star x$ \\
\hline 52. & Trakų r. SVB & 3 & & & & & 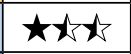 & $\star \star$ \\
\hline 53. & Ukmergės r. SVB & 3 & & & & & 大t女t & $\star \star \star$ \\
\hline 54. & Utenos r. SVB & 3 & & & & & $\star \star \star \star \star x$ & $\star \star \star \star \star x\}$ \\
\hline 55. & Varėnos r. SVB & 2 & & & & & $\star \star \star x t$ & $\star \star \star x$ \\
\hline 56. & Vilkaviškio r. SVB & 3 & & & & & th & t女 \\
\hline 57. & Vilniaus $\mathrm{m}$. SVB & 5 & & & & & $\star \star$ & $\star \star \star$ \\
\hline 58. & Vilniaus r. SVB & 4 & & & & & - & - \\
\hline 59. & Visagino SVB & 2 & & & & & - & - \\
\hline 60. & Zarasų r. SVB & 2 & & & & & 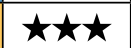 & 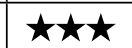 \\
\hline
\end{tabular}




\subsubsection{3 ir $2014 \mathrm{~m}$. tyrimų rezultatų palyginimas ${ }^{4}$}

Atlikus 2013 m. ir 2014 m. tyrimų rezultatu palyginimą, bibliotekas galima suskirstyti i 3 grupes:

- pirma grupé - tai savivaldybių tinklo bibliotekos (SVB), kurių vertinimo rezultatai sutapo su šių savivaldybių pagrindinių viešųjų bibliotekų (CB) vertinimo rezultatais (69 lentelè);

- antra grupé - tai savivaldybiu tinklo bibliotekos (SVB), kurių vertinimo rezultatai yra geresni nei šių savivaldybių pagrindinių viešujų biblioteku (CB) vertinimo rezultatai (70 lentelè);

- trečia grupé - tai savivaldybių tinklo bibliotekos (SVB), kuriu vertinimo rezultatai yra blogesni nei šių savivaldybių pagrindinių viešųjų bibliotekų $(\mathrm{CB})$ vertinimo rezultatai (71 lentelè).

69 lenteleje yra pateikiami savivaldybių tinklo bibliotekų vertinimo rezultatai, kurie sutapo su šių savivaldybių pagrindinių viešųjų bibliotekų vertinimo rezultatais. Šioje grupëje yra 12 SVB. Pagal pasiektus rezultatus išsiskiria Ignalinos rajono SVB: tiek savivaldybès tinklo bibliotekos, tiek pagrindinè viešoji biblioteka surinko maksimalų žvaigždžiu skaičiu (4). Gerų rezultatų pasiekè Joniškio ir Molètų rajonų SVB: šių savivaldybių tinklo bibliotekos ir pagrindinès viešosios bibliotekos surinko po 3 žvaigždes. Minimalu ịvertinimą (0,5 žvaigždès) gavo Vilkaviškio rajono savivaldybès tinklo bibliotekos ir pagrindinè viešoji biblioteka.

Čia ir toliau tekste, lyginant 2013 m. tyrimo ir 2014 m. tyrimo rezultatus, buvo remiamasi tuo pačiu šaltiniu: Jaskonienė, Dalia. Savivaldybių pagrindinių viešųjų bibliotekų veiklos tyrimas taikant BIX (Bibliotheksindex) metodiką. Bibliotekų tyrimai Lietuvoje: mokslinių straipsnių rinkinys. T. 1. Vilnius: Lietuvos nacionalinė Martyno Mažvydo biblioteka, 2015, p. 181-268. 
69 lentelè. 2013 m. ir 2014 m. tyrimu rezultatai (SVB ir CB veiklos vertinimo rezultatai sutampa)

\begin{tabular}{|c|l|c|}
\hline $\begin{array}{c}\text { Eil. } \\
\text { Nr. }\end{array}$ & \multicolumn{1}{|c|}{ SVB ir CB, kurių vertinimo rezultatai sutampa } & $\begin{array}{c}\text { SVB ir CB žvaigždžių } \\
\text { skaičius }\end{array}$ \\
\hline 1. & Biržų r. SVB ir CB & 1,5 \\
\hline 2. & Ignalinos r. SVB ir CB & 4,0 \\
\hline 3. & Elektrènų SVB ir CB & 1,5 \\
\hline 4. & Joniškio r. SVB ir CB & 3,0 \\
\hline 5. & Klaipèdos m. SVB ir CB & 3,5 \\
\hline 6. & Molètų r. SVB ir CB & 3,0 \\
\hline 7. & Pakruojo r. SVB ir CB & 1,5 \\
\hline 8. & Šiaulių m. SVB ir CB & 1,5 \\
\hline 9. & Širvintų r. SVB ir CB & 2,0 \\
\hline 10. & Tauragès r. SVB ir CB & 1,0 \\
\hline 11. & Ukmergės r. SVB ir CB & 2,0 \\
\hline 12. & Vilkaviškio r. SVB ir CB & 0,5 \\
\hline
\end{tabular}

70 lentelëje yra pateikiami savivaldybių tinklo bibliotekų (SVB) vertinimo rezultatai, kurie yra geresni negu šių savivaldybių pagrindinių viešųjų biblioteku (CB) rezultatai. Šioje grupèje yra 21 biblioteka. Šiame tyrime Rokiškio rajono SVB pasiekè maksimalų rezultatą surinkdama 4 žvaigždes, o jos pagrindinè viešoji biblioteka buvo gavusi 2 žvaigždes. Kèdainių rajono SVB tinklo rezultatai yra žymiai geresni (3,5 žvaigždès) nei pagrindinès bibliotekos (CB), kurios veikla buvo ịvertinta 0,5 žvaigždès, Pasvalio rajono SVB - 4,0 (CB - 3,0), Marijampolès SVB 3,5 žvaigždès $(\mathrm{CB}-1,5)$. Kitu savivaldybiu tinklo bibliotekų vertinimai yra labai panašūs ì šių savivaldybių pagrindinių bibliotekų vertinimus; be to, šių vertinimų skirtumai vidutiniškai ne didesni kaip 1 žvaigždè, o dažniausiai - tik 0,5 žvaigždès. 
70 lentelè. 2013 m. ir 2014 m. tyrimu rezultatai (SVB, kuriu veiklos vertinimo rezultatai geresni negu $C B$ )

\begin{tabular}{|c|c|c|}
\hline $\begin{array}{l}\text { Eil. } \\
\text { Nr. }\end{array}$ & SVB, kurių vertinimo rezultatai geresni negu CB & $\begin{array}{c}\text { SVB ir CB žvaigždžių } \\
\text { skaičius }\end{array}$ \\
\hline 1. & Anykščių r. SVB & 3,0 ir 1,0 \\
\hline 2. & Birštono SVB & 3,5 ir 3,0 \\
\hline 3. & Druskininkų SVB & 1,5 ir 0,5 \\
\hline 4. & Jonavos r. SVB & 3,0 ir 2,5 \\
\hline 5. & Jurbarko r. SVB & 3,0 ir 1,5 \\
\hline 6. & Kaišiadorių r. SVB & 2,5 ir 2,0 \\
\hline 7. & Kauno m. SVB & 3,0 ir 0,5 \\
\hline 8. & Kelmès r. SVB & 3,0 ir 2,0 \\
\hline 9. & Kèdainių r. SVB & 3,5 ir 0,5 \\
\hline 10. & Klaipèdos r. SVB & 2,5 ir 1,0 \\
\hline 11. & Marijampolès SVB & 3,5 ir 1,5 \\
\hline 12. & Neringos SVB & 1,0 ir 0,5 \\
\hline 13. & Panevėžio m. SVB & 2,5 ir 2,0 \\
\hline 14. & Panevėžio r. SVB & 2,5 ir 1,0 \\
\hline 15. & Pasvalio r. SVB & 4,0 ir 3,0 \\
\hline 16. & Prienų r. SVB & 1,0 ir 0,5 \\
\hline 17. & Radviliškio r. SVB & 3,0 ir 2,5 \\
\hline 18. & Rokiškio r. SVB & 4,0 ir 2,0 \\
\hline 19. & Šalčininkų r. SVB & 2,0 ir 1,0 \\
\hline 20. & Švenčionių r. SVB & 1,0 ir 0,5 \\
\hline 21. & Telšių r. SVB & 2,5 ir 1,5 \\
\hline
\end{tabular}

71 lentelëje yra pateikiami savivaldybių tinklo bibliotekų (SVB) vertinimo rezultatai, kurie yra blogesni negu šiu savivaldybiu pagrindiniu viešųjų bibliotekų (CB) vertinimo rezultatai. Šioje grupëje yra 25 SVB. 2013 m. atlikus tyrimą, visos savivaldybių CB gavo įvertinimus, $2014 \mathrm{~m}$. tyrimo rezultatai parodè, kad 5 savivaldybių tinklo bibliotekos (SVB) liko be ịvertinimų: Akmenès (CB - 0,5 žvaigždès), Kretingos (CB - 1,0) ir Šilalès rajonu $(\mathrm{CB}-2,5)$, Visagino miesto $(\mathrm{CB}-1,0)$ ir Vilniaus rajono $(\mathrm{CB}-0,5)$ SVB. Kitų savivaldybių tinklo bibliotekų ir šių savivaldybių 
pagrindinių viešųu bibliotekų vertinimų skirtumai yra vidutiniškai ne didesni kaip 1 žvaigždè, o dažniausiai - tik 0,5 žvaigždès.

71 lentelè. $2013 \mathrm{~m}$. ir $2014 \mathrm{~m}$. tyrimu rezultatai (SVB, kuriu veiklos vertinimo rezultatai blogesni negu $C B$ )

\begin{tabular}{|c|c|c|}
\hline $\begin{array}{l}\text { Eil. } \\
\text { Nr. }\end{array}$ & SVB, kurių vertinimo rezultatai blogesni negu CB & $\begin{array}{c}\text { SVB ir CB žvaigždžiu } \\
\text { skaičius }\end{array}$ \\
\hline 1. & Akmenès r. SVB & - ir 0,5 \\
\hline 2. & Alytaus r. SVB & 3,0 ir 4,0 \\
\hline 3. & Alytaus m. SVB & 1,5 ir 3,0 \\
\hline 4. & Kalvarijos SVB & 1,0 ir 1,5 \\
\hline 5. & Kauno r. SVB & 2,0 ir 3,0 \\
\hline 6. & Kazlų Rūdos SVB & 2,0 ir 3,0 \\
\hline 7. & Kretingos r. SVB & - ir 1,0 \\
\hline 8. & Kupiškio r. SVB & 1,5 ir 2,0 \\
\hline 9. & Lazdijų r. SVB & 1,0 ir 2,0 \\
\hline 10. & Mažeikių r. SVB & 0,5 ir 1,5 \\
\hline 11. & Pagėgių SVB & 2,5 ir 3,0 \\
\hline 12. & Palangos SVB & 1,5 ir 3,0 \\
\hline 13. & Plungès r. SVB & 2,0 ir 2,5 \\
\hline 14. & Raseinių r. SVB & 1,0 ir 1,5 \\
\hline 15. & Rietavo SVB & 1,5 ir 3,0 \\
\hline 16. & Skuodo r. SVB & 2,0 ir 2,5 \\
\hline 17. & Šakių r. SVB & 1,0 ir 3,0 \\
\hline 18. & Šilalès r. SVB & - ir 2,5 \\
\hline 19. & Šilutes r. SVB & 3,0 ir 3,5 \\
\hline 20. & Trakų r. SVB & 2,0 ir 2,5 \\
\hline 21. & Utenos r. SVB & 3,5 ir 4,0 \\
\hline 22. & Varėnos r. SVB & 2,5 ir 3,0 \\
\hline 23. & Vilniaus r. SVB & - ir 0,5 \\
\hline 24. & Visagino SVB & - ir 1,0 \\
\hline 25. & Zarasų r. SVB & 3,0 ir 4,0 \\
\hline
\end{tabular}




\subsection{Tyrimo duomenų apibendrinimas}

Tyrimo metu buvo ịvertinta apskričių teritorijose veikiančių SVB veikla ir kiekvienoje iš 4 pagrindinių dimensijų: Ištekliai ir infrastruktūra, Naudojimasis biblioteka, Našumas, Pletra - joms skirta vieta; papildomai pagal atitinkamą metodiką nustatyta bendroji kiekvienos bibliotekos vieta.

Bibliotekų vertinimas taikant BIX metodiką išryškina kiekvienos ju stiprybes ir silpnybes, parodo, kuriuos išteklius ar infrastruktūrą reikia plètoti, kurias veiklos sritis tobulinti. Didesnes galimybes gauti aukštesnị ịvertinimą galutiniame reitinge turi ta biblioteka, kurioje optimaliai subalansuoti ir tolygiai plètojami visi ištekliai ir paslaugos, užtikrinantys naudojimosi jais intensyvumą ir lemiantys bibliotekos veiklos efektyvumą, sudarytos galimybès bibliotekos plètrai prisitaikant prie pokyčiu.

BIX metodikoje naudojami rodikliai padeda atskleisti bibliotekos galimybių ir jos veiklos rezultatų sąsajas. Sugrupavus rodiklius ị 4 dimensijas, akivaizdžiai parodoma jų tarpusavio sąveika: išteklių ir paslaugu pasiūla daro įtaką gyventojų naudojimuisi biblioteka; naudojimosi bibliotekos ištekliais ir paslaugomis intensyvumas lemia bibliotekos veiklos efektyvumą ir daro ịtaką vienos paslaugos kainai; biblioteku plètrai skirtos investicijos užtikrina išteklių ir paslaugu pasiūlą. BIX rodikliai leidžia ivertinti ne tik bibliotekos personalo pastangas siekiant geru veiklos rezultatu, bet ir bibliotekos steigèju bei rèmèjų indèlį užtikrinant bibliotekos išteklius, infrastruktūros būklę ir veiklos sąlygas, kurios turi lemiamą įtaką veiklos rodikliams. Bibliotekos galimybių ir veiklos rezultatu sąsaju atskleidimas padeda pagrịsti būtinų išteklių reikalingumą bei plètrą ir yra itin reikšmingas bibliotekų atstovavimui savininko funkcijas vykdančiose institucijose, o bibliotekų savininkams ir rèmëjams suteikia galimybę įsitikinti finansinių investicijų prasmingumu ir nauda. Biblioteku vertinimas taikant BIX metodiką įtikinamai parodo, kad geriausi rezultatai ir didžiausias veiklos efektyvumas yra pasiekiami tik bendromis bibliotekų ir jų savininkų pastangomis. 
Apibendrinti $2014 \mathrm{~m}$. tyrimo rezultatai ir jų palyginimas su $2013 \mathrm{~m}$. tyrimo duomenimis rodo, kad SVB vertinimo rezultatai ir šių savivaldybių pagrindinių bibliotekų (CB) vertinimai yra labai panašūs arba sutampa su jais: šių vertinimų skirtumai dažniausiai yra vidutiniškai ne didesni kaip 1 žvaigždė arba tik 0,5 žvaigždès. Artimos arba sutampančios tų pačių savivaldybių pagrindinių ir viso tinklo bibliotekų pozicijos reitinge, vertinant rodiklius dvejus metus iš eilès, atskleidžia tam tikras viešujų bibliotekų būklès ir raidos tendencijas kiekvienoje savivaldybejje ir leidžia daryti prielaidą, kad teigiamiems pokyčiams reikalingos ilgalaikès suvienytos bibliotekų ir jų savininkų (steigejuc) pastangos. Ypač tai taikytina I dimensijos (Ištekliai ir infrastruktūra) rodikliams, kurių bent kiek žymesnę kaitą galima užtikrinti per ilgesnị nei vienerių metų laikotarpi.

Šiame tyrime naudojamų rodiklių vertė nemažai priklauso nuo SVB struktūrinių teritorinių padalinių (filialu) skaičiaus ir racionalaus jų išdèstymo teritorijoje, nuo investicijų i SVB tinklo bibliotekų išteklių ir paslaugu pletrą, t. y. nuo veiksnių, kuriuos lemia bibliotekų savininkų (steigejju) priimami sprendimai (šiuo atveju rajonų ar miestų savivaldybès). SVB tinklo bibliotekų vertinimas ir rodiklių palyginimas su kitų šalies savivaldybių SVB yra svarbus ir vertingas biblioteku atstovavimo įrankis savivaldybėse.

\subsection{Rekomendacijos}

1. Savivaldybès turi nemažai galimybių stiprinti viešąsias bibliotekas sau priskirtose teritorijose. Svarbiausia užtikrinti, kad bibliotekų ištekliai: pastatai, patalpos, dokumentų fondas (ypač ta jo dalis, kurią sistemingai atnaujinti teisės aktų tvarka yra įpareigota vietos savivalda) - būtų tinkamai palaikomi, atnaujinama informacinių technologijų infrastruktūra, o bibliotekų personalas turètų galimybę sistemingai ugdyti savo kompetencijas, nes tai yra svarbiausios šios institucijos priemonès, užtikrinančios joms galimybę adekvačiai veikti. 
2. Atlikto tyrimo „Lietuvos savivaldybių viešųų bibliotekų integravimas ị savivaldos kultūros ir socialinès plètros strategijas" (Skuodytė, E.; Biveinis, P., 2015) duomenys rodo, jog savivaldybių tarnautojai, ypač politikai, iš dalies stokoja tiesiogiai susijusios, svarbios informacijos apie viešųjų bibliotekų veiklą, viešųjų bibliotekų galimybes dalyvauti teikiant savivaldybei reikalingą ir naudingą informaciją. Todèl būtų tikslinga plèsti bibliotekinius tyrimus, reguliariai atlikti ir pristatyti savivaldybès politikams ir administracijos darbuotojams savivaldybės gyventojų ir kitų savivaldybėse veikiančiu subjektų biblioteku paslaugu poreikio tyrimus, biblioteku teikiamų paslaugu kokybès vertinimus, o šiame straipsnyje apžvelgiamo tyrimo „Savivaldybių viešųų bibliotekų sistemos veiklos tyrimas taikant BIX (Bibliotheksindex) metodiką“" medžiaga naudotis kaip vienu šaltiniu, padedančių formuoti viešujų bibliotekų ir savivaldos tarpusavio santykius, taip pat rengti biblioteku plètros politikos savivaldybejje nuostatas.

3. Reguliarus kiekvienais metais pagal BIX metodiką vykdomas SVB veiklos vertinimas, jų reitingo skelbimas viešojoje erdvejje padètų atskleisti pakankamai objektyvią informaciją apie kiekvienos SVB būklę ir veiklos rezultatus, sudarytų galimybę stebèti pokyčius ir plètros tendencijas, labiau išryškintų jų stipriuosius bruožus ir veiklos trūkumus, atskleistų tobulintinas veiklos sritis ir numatytos veiklos gerinimo priemones.

4. Taikant BIX metodiką, reikalingi statistiniai duomenys, kurie pateikiami SVB statistinèse ataskaitose arba papildomai. Tačiau ne visi šie duomenys yra pakankamai tikslūs ir patikimi, todèl atsiranda paklaidų, kurios nepagrịstai nulemia aukštesnę arba žemesnę SVB reitinge tenkančią vietą. Tikètina, kad didesni statistinių duomenų patikimumą padètu užtikrinti realus, o ne bandomasis biblioteku vertinimas, SVB iš anksto informuojant apie ji ir ịpareigojant tiksliai fiksuoti visus tyrimui būtinus duomenis nuo kalendorinių metų pradžios iki pabaigos. 


\section{Literatūra}

1. BIX. Der Bibliotheksindex [interaktyvus]. Berlin: Deutscher Bibliotheksverband [žiūrèta 2014-12-09]. Internetine prieiga: http://www.bix-bibliotheksindex.de/

2. BROPHY, P. Measuring library performance: principles and techniques. London: Facet publishing, 2006. 242 p. ISBN 978-1856045933

3. Cross-European survey to measure users' perceptions of the benefits of ICT in public libraries. QUICK, S.; PRIOR, G.; TOOMBS, B.; TAYLOR, L.; CURRENTI, R. [interaktyvus]. Washington: TNS [žiūrèta 2014-12-30]. Internetinè prieiga: https://digital.lib. washington.edu/researchworks/bitstream/handle/1773/22718/Final\%20Report\%20 \%20CrossEuropean\%20Library\%20Impact.pdf?sequence=1

4. DVORAK, J.; RUDŽIONIENĖ, J. Biblioteku kaip viešojo sektoriaus instituciju veiklos vertinimo organizavimo galimybe viešojo administravimo požiūriu [interaktyvus]. Vilnius: Vilniaus universitetas [žiūrèta 2014-12-30]. Internetinè prieiga: http://www.zurnalai.vu.lt/files/journals/163/articles/1592/public/43-64.pdf

5. Economic value and impact of public libraries in Latvia: study report [interaktyvus]. Ryga: Kultūras informācijas sistēmu centrs [žiūrèta 2014-01-22]. Internetiné prieiga: http://www.kis.gov.lv/download/Economic\%20value\%20and\%20impact $\% 20$ of $\% 20$ public\%20libraries\%20in\%20Latvia.pdf

6. HUYSMANS, F.; OOMES, M. Measuring the public library's societal value: a methodological research model. In Information in e-Motion: Proceedings BOBCATSSS2012, 20th International Conference on Information Science, abstracts, Amsterdam, 23-25 January 2012. Bad Honnef: BOCK+HERCHEN Verlag, p. 55. ISBN 978-3-88347286-7

7. ISO 2789:2013 (E) Information and documentation - International library statistics, $5^{\text {th }}$ ed., Geneva: International Organization for Standardization, 2013.71 p.

8. ISO 11620:2014 Information and documentation - Library performance indicators, $2^{\text {nd }}$ ed., Geneva: International Organization for Standardization, 2014. 86 p.

9. JASKONIENĖ, D. Savivaldybių pagrindinių viešųjų bibliotekų reitingas. Tarp knygu, 2014, kovas, Nr. 3 (662), p. 14-21. ISSN 0868-8826

10. JASKONIENE, D. Savivaldybių viešųjų bibliotekų reitingas. Tarp knygu, 2015, lieparugpjūtis, Nr. 7-8 (678-679), p. 2-6; rugsëjis, Nr. 9 (680), p. 6-11. ISSN 0868-8826

11. KAPLAN, R. S.; NORTON, D. P. The balanced scorecard: measures that drive performance. Harvard Business Review: The Best of HBR 1992, 2005, July-August, p. 1-10. ISSN 00178012

12. KVIETKAUSKIENĖ, R. IFLA reikalavimai viešujų biblioteka veiklai. Šiandien aktualu, 2001, Nr.1, p. 3-13. ISSN 1392-1428

13. LANCASTER, W. F. If you want to evaluate your library... 2nd ed. London: Library Association Publishing, 1993. 352 p. ISBN 978-0878450787

14. Lietuvos Respublikos terminu bankas [interaktyvus]. Vilnius: Valstybinè lietuvių kalbos komisija [žiūrèta 2015-04-05]. Internetinè prieiga:

http: //terminai.vlkk.lt/pls/tb/tb.result

15. Lietuvos valstybinès reikšmès ir apskričiu viešuju biblioteka strategiju, kokybiniu ir kiekybiniu veiklos rodikliu tyrimas [interaktyvus]. [žiūrèta 2014-04-12]. Internetinè prieiga: http://www.esparama.lt/es_parama_pletra/failai/ESFproduktai/2013_strategiju_veiklos_rodikliu_metodika.pdf 
16. MUNDT, S. BIX - The Bibliotheksindex: statistical benchmarking in German. In Public Libraries, Proceedings of the conference held in Montreal on 18-19 August reporting on the Global Library Statistics Project, Library statistics for the twenty-first century world [interaktyvus]. München: K. G. Saur, 2009. p. 188-195 [žiūrèta 2013-12-09]. Internetine prieiga: http://www.degruyter.com/view/product/41428

17. PARMENTER, D. Key performance indicators: developing, implementing and using winning KPIs. $2^{\text {nd }}$ edition. Hoboken: Wiley \& Sons, 2010. 299 p. ISBN 978-0-47054515-7

18. POLL, R.; BOEKHORST, p. Measuring quality: performance measurement in libraries / series publications IFLA. $2^{\text {nd }}$ revised edition [interaktyvus]. [žiūrèta 2013-12-09]. München: K. G. Saur, 2007. 269 p. Internetinė prieiga: http://www.degruyter.com/ view/product $/ 37583$

19. RUDŽIONIENĖ, J. Bibliotekos veiklos vertinimo ABC: mokomoji knyga. Vilnius: Vilniaus universiteto leidykla, 2010. 80 p. ISBN 978-9955-33-550-4

20. RUDŽIONIENÉ, J. Culture of performance evaluation: seeking the ways of better quality library management and university teaching methodology. Tiltai, 2012, Nr. 1 (58), p. 149-158. ISSN 1392-313

21. RUTKAUSKIENĖ, U. Viešuju biblioteku socialinis ir ekonominis poveikis vartotojams: daktaro disertacija. Humanitariniai mokslai, komunikacija ir informacija $(06 \mathrm{H})$. [interaktyvus]. Vilnius, 2009. 236 p. [žiūrèta 2015-04-05]. Prieiga per internetą http:// vddb.library.lt/fedora/get/LT-eLABa-0001:E.02-2009-D_2009

22. SKUODYTE், E.; BIVEINIS, p. (2015). Lietuvos savivaldybių viešųų bibliotekų integravimas ị savivaldos kultūros ir socialinès plètros strategijas. Iš Biblioteku tyrimai Lietuvoje: mokslinių straipsnių rinkinys. T. 1, Vilnius: Lietuvos nacionalinė Martyno Mažvydo biblioteka, 2015, p. 10-171. ISBN 978-609-405-112-8

23. Vartotoju nuomone apie informaciniu ir komunikaciniu technologiju nauda Lietuvos viešosiose bibliotekose: $2013 \mathrm{~m}$. tyrimo ataskaita / parengè QUICK, S.; PRIOR, G.; TOOMBS, B.; TAYLOR, L.; CURRENTI, R. Vilnius: Lietuvos nacionalinė Martyno Mažvydo biblioteka, 2013. 24 p. ISBN 978-609-405-084-8

24. Viě̌ojo sektoriaus kultūros ịstaigu veiklos vertinimo kriteriju nustatymas: galutinè ataskaita [interaktyvus]. [žiūrèta 2014-12-11]. Internetinè prieiga: http://www.aksk.lt/wp-content/uploads/2013/08/Ilataskaita.pdf

\section{Šaltiniai}

1. LIBIS bibliotekų statistikos modulis [interaktyvus]. Vilnius: Lietuvos nacionalinè Martyno Mažvydo biblioteka [žiūrèta 2014-12-09]. Internetinè prieiga: http://statistika. libis.lt:7878/pls/apex/f?p=106)

2. Lietuvos statistikos departamentas [interaktyvus]. Vilnius: Lietuvos statistikos departamentas [žiūrèta 2014-12-09]. Internetinè prieiga: http://www.stat.gov.lt/ 


\title{
STUDY OF THE PERFORMANCE OF THE MUNICIPAL PUBLIC LIBRARY SYSTEM BY APPLYING THE BIX (BIBLIOTHEKSINDEX) METHODOLOGY
}

\author{
Dalia JASKONIENE
}

\section{SUMMARY}

In 2013, the Martynas Mažvydas National Library of Lithuania together with Lithuanian regional public libraries prepared and carried out the study "Application of the BIX (Bibliotheksindex) methodology for evaluating the performance of Lithuanian public libraries". The study involved evaluation of public libraries based on the BIX methodology widely known in the EU. The main goal of the study was to evaluate the main municipal public libraries by applying the BIX methodology. 58 public libraries were selected as the object of the analysis. The results revealed that it would be much more efficient to evaluate not only the main libraries but also the entire system of municipal public libraries. More precise and objective evaluation would be guaranteed by calculating performance indicators of the entire public library system; therefore in 2014, the 2nd stage of the study "Evaluation of the performance of municipal public library system by applying the BIX (Bibliotheksindex) methodology" was carried out. The main goal of the study was to evaluate and rate municipal public libraries by applying the BIX methodology. The subject of the study was the performance of 60 systems of municipal public libraries (1281 libraries in total). The study pursued the following tasks: 
1) evaluating the performance of regional municipal public libraries and defining their position within each of the following 4 dimensions: resources and infrastructure, library use, effectiveness, and development;

2) defining the suitability of performance indicators for evaluating and rating municipal public libraries: describing indicators and interpreting options of their application, characterizing internal and external library factors which impacted performance indicators determined by applying the BIX methodology;

3) evaluating and rating systems of Lithuanian municipal public libraries and comparing the results from the 2013 and the 2014 studies.

Applying the BIX methodology resulted in a framework for rating public libraries: the results from applying $B I X$ show the position of each municipal public library within each of the 4 dimensions (18 indicators) with relation to other libraries; in addition, by applying an appropriate methodology, the overall position of each municipal public library within the evaluation scale is identified. Municipal public library indicators and acquired results are evaluated and arranged according to the size of the community served by a particular library.

The time period of the study is 2013. Statistical data for this year was taken from statistical reports of municipal public libraries presented within the statistics module. The population size as of the end of 2013 (or beginning of 2014) was taken from databases of Statistics Lithuania. In addition to the evaluation and rating of library performance, study results from both studies (2013 and 2014) were compared.

The summarized study results and their comparison with the findings from the 2013 study show that the highest ratings were for those municipal public libraries, the main libraries of which received the highest assessment, whereas the lowest scores were assigned to libraries, the main libraries of 
which did not receive high ratings. Similar or coinciding positions of the main libraries and other libraries within the network when comparing indicators from two consecutive years show certain tendencies of the situation and development of public libraries of each municipality and suggest that positive changes require long-term joint efforts of libraries and their stakeholders. It is particularly relevant to indicators of the dimension "Resources and infrastructure" characterizing library resources at least minimally significant change of which can be ensured over a time period longer than one year. Evaluation of municipal public libraries and comparison of their performance indicators is a very important and valuable advocacy tool when dealing with library stakeholders. 
PRIEDAI 


\section{1 grupès bibliotekų I-IV dimensijų rodiklių skaitinès reikšmès}

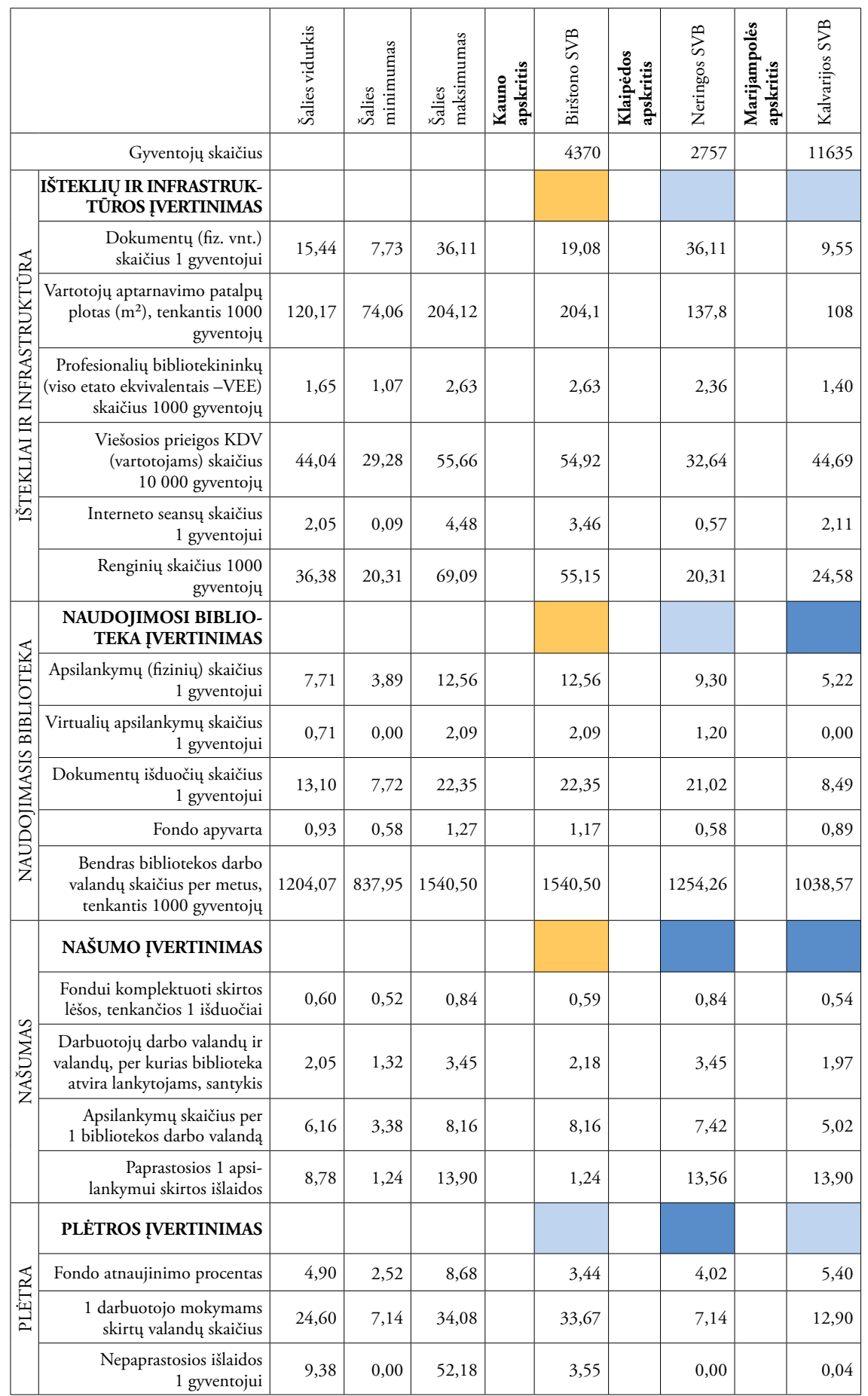


1 grupès bibliotekų I-IV dimensijų rodiklių skaitinès reikšmès (tęsinys)

\begin{tabular}{|c|c|c|c|c|c|c|}
\hline & 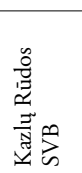 & 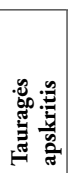 & 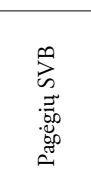 & 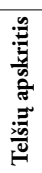 & 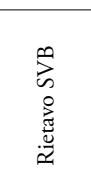 \\
\hline & Gyventojų skaičius & 12638 & & 8931 & & 8264 \\
\hline \multirow{7}{*}{ 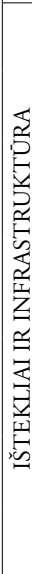 } & \begin{tabular}{|} 
IŠTEKILIU IR INFRASTRUK- \\
TŪROS ĮVERTINIMAS
\end{tabular} & & & & & \\
\hline & $\begin{array}{l}\text { Dokumentų (fiz. vnt.) } \\
\text { skaičius } 1 \text { gyventojui }\end{array}$ & 7,73 & & 11,40 & & 8,76 \\
\hline & $\begin{array}{r}\text { Vartotojų aptarnavimo patalpų } \\
\text { plotas }\left(\mathrm{m}^{2}\right) \text {, tenkantis } 1000 \\
\text { gyventojų }\end{array}$ & 74,06 & & 120,1 & & 76,84 \\
\hline & $\begin{array}{r}\text { Profesionaliu bibliotekininku } \\
\text { (viso etato ekvivalentais -VEE) } \\
\text { skaičius } 1000 \text { gyventojų }\end{array}$ & 1,07 & & 1,34 & & 1,09 \\
\hline & $\begin{array}{r}\text { Viešosios prieigos } \mathrm{KDV} \\
\text { (vartotojams) skaičius } \\
10000 \text { gyventojų }\end{array}$ & 29,28 & & 47,03 & & 55,66 \\
\hline & $\begin{array}{r}\text { Interneto seansų skaičius } \\
1 \text { gyventojui }\end{array}$ & 1,60 & & 4,48 & & 0,09 \\
\hline & $\begin{array}{r}\text { Renginių skaičius } 1000 \\
\text { gyventojų }\end{array}$ & 20,34 & & 69,09 & & 28,80 \\
\hline \multirow{6}{*}{ 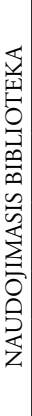 } & $\begin{array}{l}\text { NAUDOJIMOSI BIBLIO- } \\
\text { TEKA IৃERTINIMAS }\end{array}$ & & & & & \\
\hline & $\begin{array}{r}\text { Apsilankymų (fiziniu) skaičius } \\
1 \text { gyventojui }\end{array}$ & 4,24 & & 11,04 & & 3,89 \\
\hline & $\begin{array}{r}\text { Virtualių apsilankymu skaičius } \\
1 \text { gyventojui }\end{array}$ & 0,26 & & n.d. & & 0,00 \\
\hline & $\begin{array}{r}\text { Dokumentų išduočiu skaičius } \\
1 \text { gyventojui }\end{array}$ & 9,80 & & 9,24 & & 7,72 \\
\hline & Fondo apyvarta & 1,27 & & 0,81 & & 0,88 \\
\hline & $\begin{array}{r}\text { Bendras bibliotekos darbo } \\
\text { valandų skaičius per metus, } \\
\text { tenkantis } 1000 \text { gyventojų }\end{array}$ & 837,95 & & 1400,52 & & 1152,59 \\
\hline \multirow{5}{*}{$\sum_{\substack{\infty \\
\vdots \\
z}}^{\infty}$} & NAŠUMO İVERTINIMAS & & & & & \\
\hline & $\begin{array}{l}\text { Fondui komplektuoti skirtos } \\
\text { lëšos, tenkančios } 1 \text { išduočiai }\end{array}$ & 0,56 & & 0,52 & & 0,56 \\
\hline & $\begin{array}{l}\text { Darbuotojų darbo valandų ir } \\
\text { valandu, per kurias biblioteka } \\
\text { atvira lankytojams, santykis }\end{array}$ & 1,78 & & 1,32 & & 1,59 \\
\hline & $\begin{array}{r}\text { Apsilankymų skaičius per } \\
1 \text { bibliotekos darbo valandą }\end{array}$ & 5,07 & & 7,88 & & 3,38 \\
\hline & $\begin{array}{r}\text { Paprastosios } 1 \text { apsi- } \\
\text { lankymui skirtos išlaidos }\end{array}$ & 10,39 & & 3,89 & & 9,69 \\
\hline \multirow{4}{*}{ 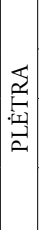 } & PLĖTROS İVERTINIMAS & & & & & \\
\hline & Fondo atnaujinimo procentas & 8,68 & & 2,52 & & 5,32 \\
\hline & $\begin{array}{r}1 \text { darbuotojo mokymams } \\
\text { skirtų valandų skaičius }\end{array}$ & 31,00 & & 28,82 & & 34,08 \\
\hline & $\begin{array}{r}\text { Nepaprastosios išlaidos } \\
1 \text { gyventojui }\end{array}$ & 0,48 & & 0,00 & & 52,18 \\
\hline
\end{tabular}




\section{2 grupès bibliotekų I-IV dimensijų rodiklių skaitinès reikšmès}

\begin{tabular}{|c|c|c|c|c|c|c|c|c|c|}
\hline & $\begin{array}{l}\frac{n}{y} \\
\frac{y}{3} \\
\cdot \frac{0}{5} \\
\frac{\tilde{y}}{3} \\
\frac{.}{n}\end{array}$ & 畐 & 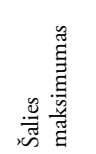 & 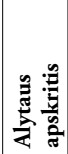 & 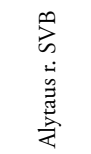 & 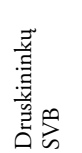 & 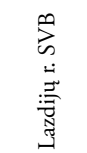 & 害营 \\
\hline & Gyventojų skaičius & & & & & 27356 & 20947 & 21251 & \\
\hline \multirow{7}{*}{ 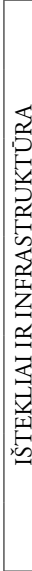 } & \begin{tabular}{|} 
IŠTEKLIUU IR INFRASTRUK- \\
TÜROS İVERTINIMAS
\end{tabular} & & & & & & & & \\
\hline & $\begin{array}{r}\text { Dokumentu (fiz. vnt.) } \\
\text { skaičius } 1 \text { gyventojui }\end{array}$ & 9,01 & 5,52 & 14,01 & & 14,01 & 7,91 & 12,02 & \\
\hline & $\begin{array}{r}\text { Vartotojų aptarnavimo patalpų } \\
\text { plotas }\left(\mathrm{m}^{2}\right) \text {, tenkantis } 1000 \\
\text { gyventojų }\end{array}$ & 97,19 & 38,87 & 141,30 & & 115,92 & 57,67 & 132,04 & \\
\hline & $\begin{array}{r}\text { Profesionalių bibliotekininku } \\
\text { (viso etato ekvivalentais -VEE) } \\
\text { skaičius } 1000 \text { gyventojų }\end{array}$ & 1,52 & 0,73 & 2,25 & & 1,56 & 0,86 & 1,69 & \\
\hline & $\begin{array}{r}\text { Viešosios prieigos KDV } \\
\text { (vartotojams) skaičius } \\
10000 \text { gyventojų }\end{array}$ & 41,19 & 9,69 & 83,15 & & 47,89 & 13,84 & 71,06 & \\
\hline & $\begin{array}{r}\text { Interneto seansų skaičius } \\
1 \text { gyventojui }\end{array}$ & 2,18 & 0,09 & 8,84 & & 2,41 & 1,33 & 1,98 & \\
\hline & $\begin{array}{r}\text { Renginių skaičius } 1000 \\
\text { gyventojų }\end{array}$ & 28,12 & 9,37 & 45,73 & & 26,28 & 16,85 & 32,23 & \\
\hline \multirow{6}{*}{ 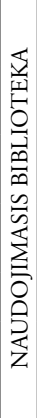 } & $\begin{array}{l}\text { NAUDOJIMOSI BIBLIO- } \\
\text { TEKA IৃVERTINIMAS }\end{array}$ & & & & & & & & \\
\hline & $\begin{array}{r}\text { Apsilankymų (fiziniu) skaičius } \\
1 \text { gyventojui } \\
\end{array}$ & 5,98 & 1,99 & 9,05 & & 9,05 & 4,43 & 5,63 & \\
\hline & $\begin{array}{r}\text { Virtualių apsilankymų skaičius } \\
1 \text { gyventojui }\end{array}$ & 0,92 & 0,00 & 3,54 & & 0,12 & 1,26 & 0,44 & \\
\hline & $\begin{array}{r}\text { Dokumentų išduočių skaičius } \\
1 \text { gyventojui }\end{array}$ & 9,45 & 4,16 & 18,47 & & 18,47 & 6,58 & 7,06 & \\
\hline & Fondo apyvarta & 1,06 & 0,59 & 1,41 & & 1,32 & 0,83 & 0,59 & \\
\hline & $\begin{array}{r}\text { Bendras bibliotekos darbo } \\
\text { valandu skaičius per metus, } \\
\text { tenkantis } 1000 \text { gyventojų }\end{array}$ & 1241,17 & 185,70 & 2015,74 & & 1852,57 & 406,60 & 1649,15 & \\
\hline \multirow{5}{*}{ 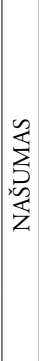 } & NAŠUMO İVERTINIMAS & & & & & & & & \\
\hline & $\begin{array}{l}\text { Fondui komplektuoti skirtos } \\
\text { léšos, tenkančios } 1 \text { išduočiai }\end{array}$ & 0,52 & 0,29 & 0,77 & & 0,30 & 0,56 & 0,57 & \\
\hline & $\begin{array}{r}\text { Darbuotojų darbo valandų ir } \\
\text { valandu, per kurias biblioteka } \\
\text { atvira lankytojams, santykis }\end{array}$ & 2,44 & 1,28 & 5,27 & & 1,28 & 3,88 & 1,52 & \\
\hline & $\begin{array}{r}\text { Apsilankymų skaičius per } \\
1 \text { bibliotekos darbo valandą }\end{array}$ & 7,10 & 3,29 & 51,67 & & 4,88 & 10,89 & 3,41 & \\
\hline & $\begin{array}{r}\text { Paprastosios } 1 \text { apsi- } \\
\text { lankymui skirtos išlaidos }\end{array}$ & 9,24 & 5,61 & 13,27 & & 6,22 & 7,53 & 10,95 & \\
\hline \multirow{4}{*}{ 変 } & PLĖTROS İVERTINIMAS & & & & & & & & \\
\hline & Fondo atnaujinimo procentas & 4,40 & 1,64 & 8,30 & & 3,01 & 3,39 & 2,82 & \\
\hline & $\begin{array}{r}1 \text { darbuotojo mokymams } \\
\text { skirtų valandų skaičius }\end{array}$ & 18,99 & 3,71 & 46,10 & & 16,33 & 23,21 & 27,28 & \\
\hline & $\begin{array}{r}\text { Nepaprastosios išlaidos } \\
1 \text { gyventojui }\end{array}$ & 23,50 & 0,00 & 384,78 & & 7,26 & 0,72 & 0,00 & \\
\hline
\end{tabular}


2 grupès bibliotekų I-IV dimensijų rodiklių skaitinès reikšmės (tęsinys)

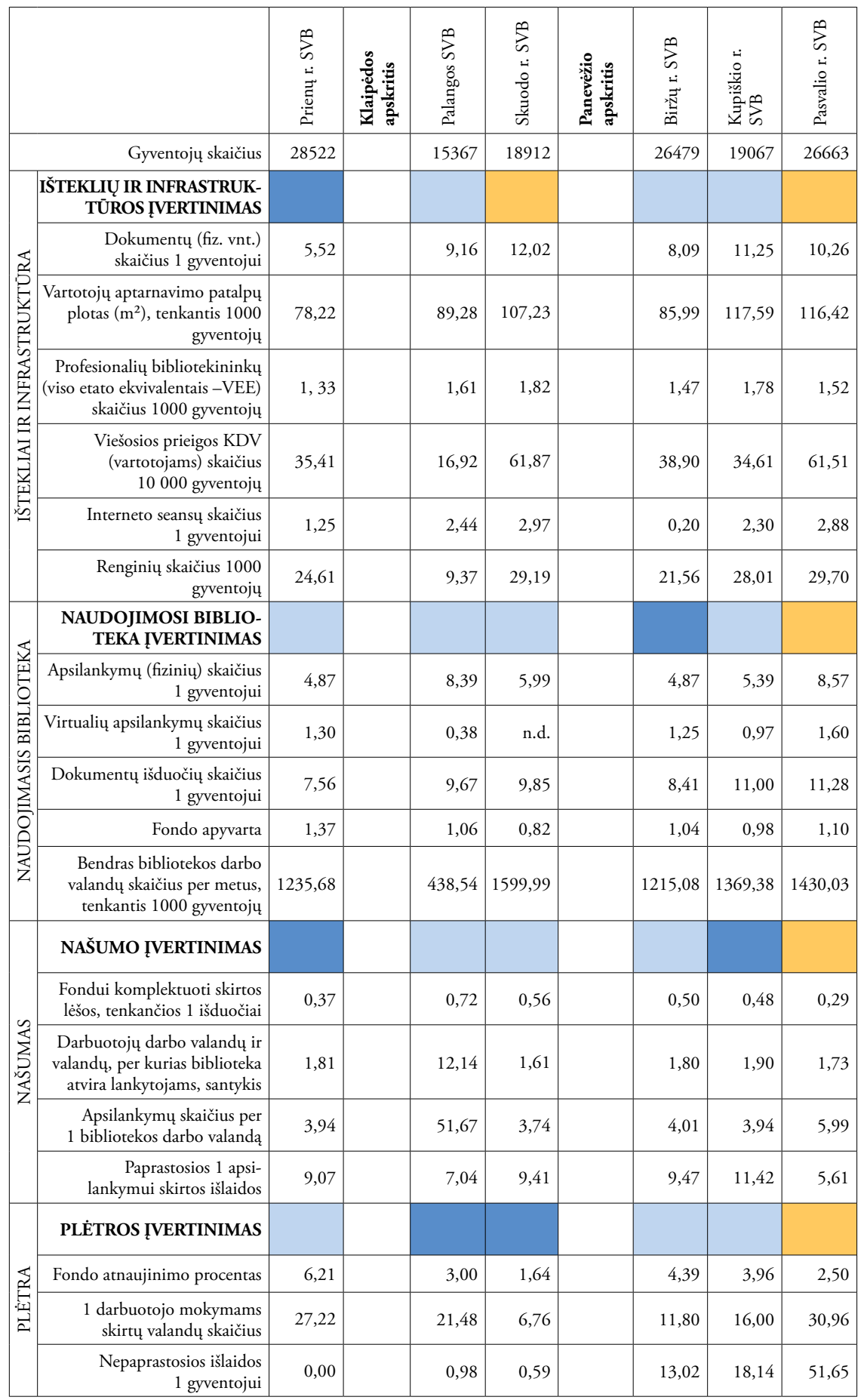


2 grupès bibliotekų I-IV dimensijų rodiklių skaitinės reikšmès (tęsinys)

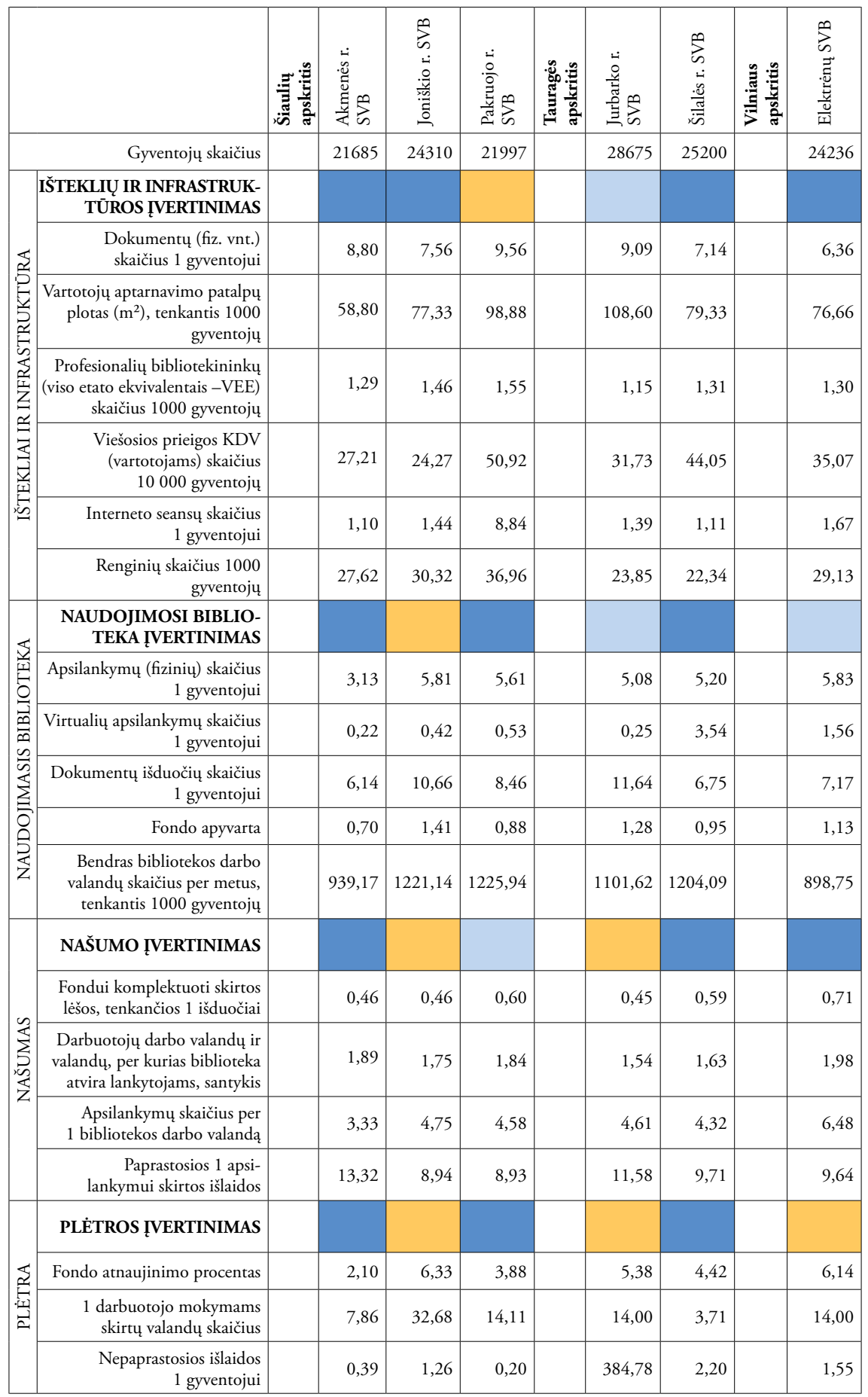


2 grupès bibliotekų I-IV dimensijų rodiklių skaitinės reikšmės (tęsinys)

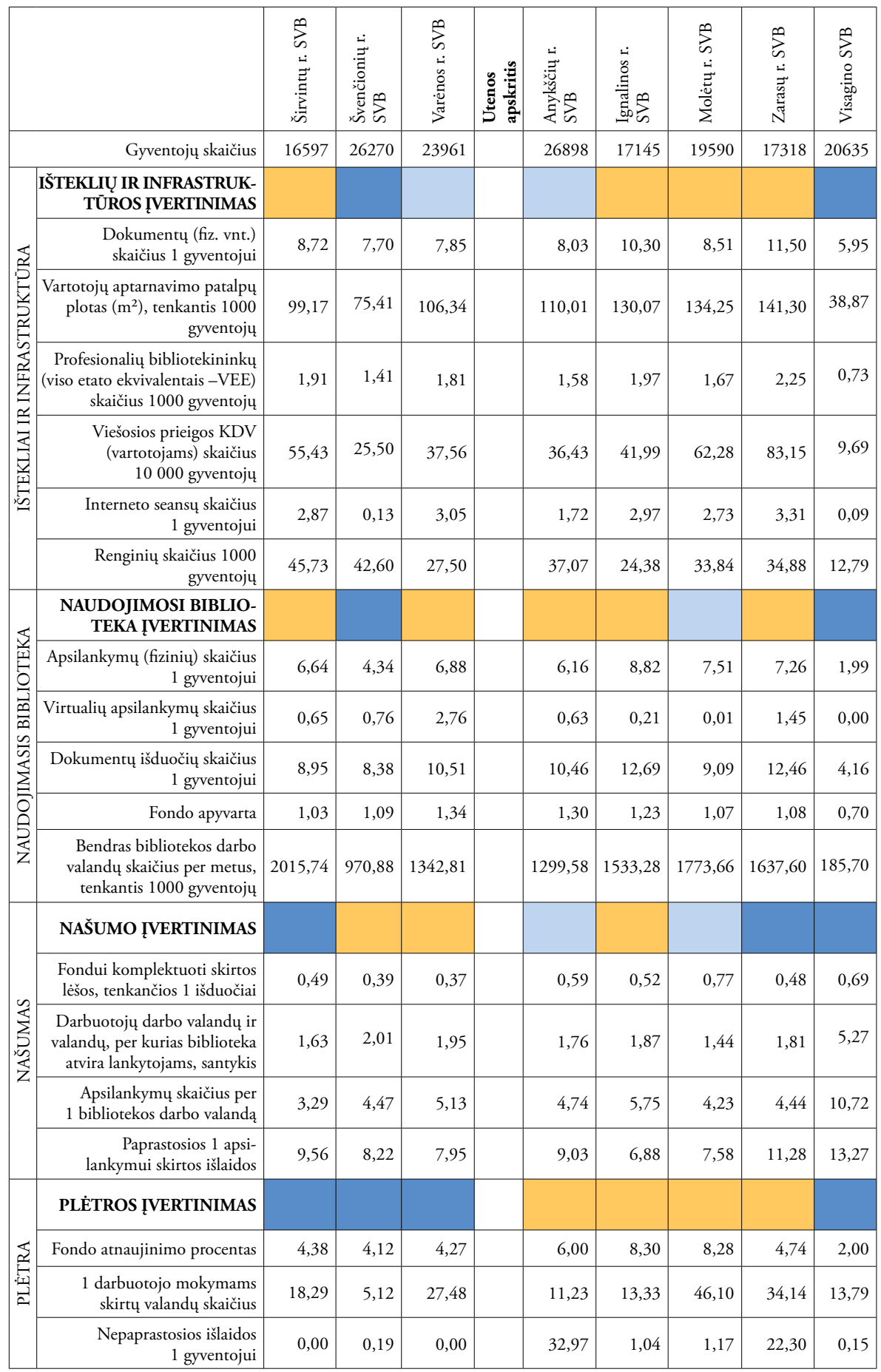




\section{3 grupès bibliotekų I-IV dimensijų rodiklių skaitinès reikšmès}

\begin{tabular}{|c|c|c|c|c|c|c|c|c|c|c|}
\hline & 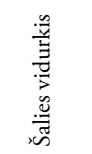 & 兽 & 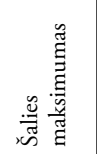 & 害 & 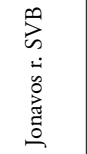 & 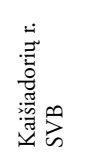 & 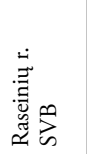 & 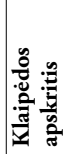 & 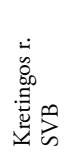 \\
\hline & Gyventojų skaičius & & & & & 44481 & 32370 & 35496 & & 40147 \\
\hline \multirow{7}{*}{ 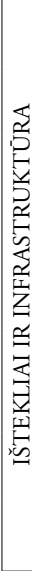 } & \begin{tabular}{|} 
IŠTEKLIUU IR INFRASTRUK- \\
TÜROS I̦VERTINIMAS
\end{tabular} & & & & & & & & & \\
\hline & $\begin{array}{r}\text { Dokumentų (fiz. vnt.) } \\
\text { skaičius } 1 \text { gyventojui }\end{array}$ & 6,68 & 3,88 & 9,60 & & 4,77 & 6,44 & 6,75 & & 5,71 \\
\hline & $\begin{array}{r}\text { Vartotojų aptarnavimo patalpų } \\
\text { plotas }\left(\mathrm{m}^{2}\right) \text {, tenkantis } 1000 \\
\text { gyventojų }\end{array}$ & 72,42 & 43,97 & 124,68 & & 43,97 & 80,51 & 77,56 & & 57,96 \\
\hline & $\begin{array}{r}\text { Profesionalių bibliotekininkų } \\
\text { (viso etato ekvivalentais -VEE) } \\
\text { skaičius } 1000 \text { gyventojų }\end{array}$ & 1,12 & 0,85 & 1,71 & & 0,85 & 1,05 & 1,16 & & 0,93 \\
\hline & $\begin{array}{r}\text { Viešosios prieigos KDV } \\
\text { (vartotojams) skaičius } \\
10000 \text { gyventojų }\end{array}$ & 29,12 & 17,54 & 40,61 & & 17,54 & 33,36 & 24,23 & & 24,16 \\
\hline & $\begin{array}{r}\text { Interneto seansų skaičius } \\
1 \text { gyventojui }\end{array}$ & 1,53 & 0,78 & 2,78 & & 1,58 & 1,84 & 1,39 & & 1,21 \\
\hline & $\begin{array}{r}\text { Renginių skaičius } 1000 \\
\text { gyventojų }\end{array}$ & 21,26 & 12,90 & 39,96 & & 15,67 & 20,08 & 21,83 & & 17,98 \\
\hline \multirow{6}{*}{ 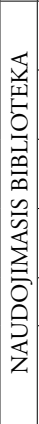 } & $\begin{array}{r}\text { NAUDOJIMOSI BIBLIO- } \\
\text { TEKA IVERTINIMAS }\end{array}$ & & & & & & & & & \\
\hline & $\begin{array}{r}\text { Apsilankymų (fiziniu) skaičius } \\
1 \text { gyventojui }\end{array}$ & 4,30 & 1,40 & 7,80 & & 3,96 & 4,66 & 3,92 & & 3,15 \\
\hline & $\begin{array}{r}\text { Virtualių apsilankymų skaičius } \\
1 \text { gyventojui }\end{array}$ & 0,95 & 0,02 & 4,77 & & 0,69 & 0,35 & 0,33 & & 1,41 \\
\hline & $\begin{array}{r}\text { Dokumentų išduočių skaičius } \\
1 \text { gyventojui }\end{array}$ & 7,32 & 3,65 & 18,19 & & 9,76 & 5,01 & 5,50 & & 6,30 \\
\hline & Fondo apyvarta & 1,10 & 0,48 & 2,04 & & 2,04 & 0,78 & 0,82 & & 1,10 \\
\hline & $\begin{array}{r}\text { Bendras bibliotekos darbo } \\
\text { valandų skaičius per metus, } \\
\text { tenkantis } 1000 \text { gyventojų }\end{array}$ & 1080,62 & 617,61 & 1861,33 & & 617,61 & 1023,71 & 988,00 & & 775,90 \\
\hline \multirow{5}{*}{ 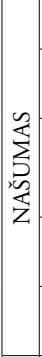 } & NAŠUMO İVERTINIMAS & & & & & & & & & \\
\hline & $\begin{array}{l}\text { Fondui komplektuoti skirtos } \\
\text { lëšos, tenkančios } 1 \text { išduočiai }\end{array}$ & 0,58 & 0,17 & 1,01 & & 0,44 & 0,76 & 0,81 & & 0,64 \\
\hline & $\begin{array}{r}\text { Darbuotoju darbo valandu ir } \\
\text { valandu, per kurias biblioteka } \\
\text { atvira lankytojams, santykis }\end{array}$ & 1,67 & 0,89 & 2,27 & & 2,27 & 1,50 & 1,78 & & 2,06 \\
\hline & $\begin{array}{r}\text { Apsilankymų skaičius per } \\
1 \text { bibliotekos darbo valandą }\end{array}$ & 4,13 & 1,62 & 7,09 & & 6,41 & 4,55 & 3,96 & & 4,06 \\
\hline & $\begin{array}{r}\text { Paprastosios } 1 \text { apsi- } \\
\text { lankymui skirtos išlaidos }\end{array}$ & 9,94 & 5,76 & 21,07 & & 8,49 & 8,12 & 10,99 & & 11,69 \\
\hline \multirow{4}{*}{ 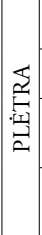 } & PLĖTROS İVERTINIMAS & & & & & & & & & \\
\hline & Fondo atnaujinimo procentas & 3,87 & 2,20 & 6,97 & & 6,97 & 4,41 & 6,73 & & 2,49 \\
\hline & $\begin{array}{r}1 \text { darbuotojo mokymams } \\
\text { skirtų valandų skaičius }\end{array}$ & 21,08 & 5,89 & 50,29 & & 9,45 & 13,75 & 13,89 & & 16,05 \\
\hline & $\begin{array}{r}\text { Nepaprastosios išlaidos } \\
1 \text { gyventojui }\end{array}$ & 7,72 & 0,00 & 72,57 & & 9,90 & 3,66 & 0,88 & & 0,00 \\
\hline
\end{tabular}


3 grupès bibliotekų I-IV dimensijų rodiklių skaitinės reikšmės (tęsinys)

\begin{tabular}{|c|c|c|c|c|c|c|c|c|c|c|}
\hline & 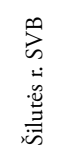 & 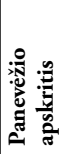 & 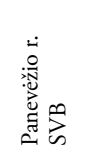 & 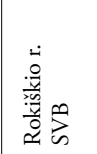 & 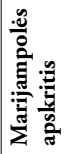 & 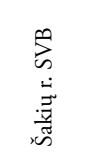 & 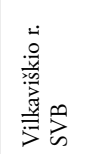 & in & 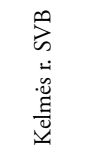 \\
\hline & Gyventojų skaičius & 42473 & & 37494 & 32754 & & 30852 & 40258 & & 30303 \\
\hline \multirow{7}{*}{ 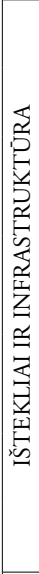 } & $\begin{array}{r}\text { IŠTEKLIUU IR INFRASTRUK- } \\
\text { TÜROS ĮVERTINIMAS }\end{array}$ & & & & & & & & & \\
\hline & $\begin{array}{r}\text { Dokumentų (fiz. vnt.) } \\
\text { skaičius } 1 \text { gyventojui }\end{array}$ & 6,03 & & 7,16 & 9,60 & & 6,24 & 7,26 & & 6,62 \\
\hline & $\begin{array}{r}\text { Vartotojų aptarnavimo patalpų } \\
\text { plotas }\left(\mathrm{m}^{2}\right) \text {, tenkantis } 1000 \\
\text { gyventojų }\end{array}$ & 65,45 & & 79,19 & 114,76 & & 63,40 & 68,96 & & 76,13 \\
\hline & $\begin{array}{r}\text { Profesionalių bibliotekininkų } \\
\text { (viso etato ekvivalentais -VEE) } \\
\text { skaičius } 1000 \text { gyventojų }\end{array}$ & 1,18 & & 1,29 & 1,71 & & 1,18 & 1,04 & & 1,17 \\
\hline & $\begin{array}{r}\text { Viešosios prieigos KDV } \\
\text { (vartotojams) skaičius } \\
10000 \text { gyventojų }\end{array}$ & 38,14 & & 40,01 & 40,61 & & 24,63 & 31,05 & & 32,01 \\
\hline & $\begin{array}{r}\text { Interneto seansų skaičius } \\
1 \text { gyventojui }\end{array}$ & 1,63 & & 2,05 & 2,78 & & 1,07 & 0,78 & & 2,04 \\
\hline & $\begin{array}{r}\text { Renginių skaičius } 1000 \\
\text { gyventojų }\end{array}$ & 17,33 & & 26,27 & 39,97 & & 21,91 & 26,55 & & 28,68 \\
\hline \multirow{6}{*}{ 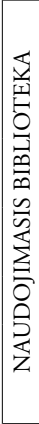 } & $\begin{array}{l}\text { NAUDOJIMOSI BIBLIO- } \\
\text { TEKA İVERTINIMAS }\end{array}$ & & & & & & & & & \\
\hline & $\begin{array}{r}\text { Apsilankymų (fiziniu) skaičius } \\
1 \text { gyventojui }\end{array}$ & 5,32 & & 4,60 & 7,80 & & 3,50 & 3,13 & & 4,34 \\
\hline & $\begin{array}{r}\text { Virtualių apsilankymų skaičius } \\
1 \text { gyventojui }\end{array}$ & 0,06 & & 4,77 & 0,41 & & 0,25 & 0,18 & & 0,46 \\
\hline & $\begin{array}{r}\text { Dokumentų išduočių skaičius } \\
1 \text { gyventojui }\end{array}$ & 9,38 & & 7,44 & 18,19 & & 6,59 & 4,66 & & 6,81 \\
\hline & Fondo apyvarta & 1,56 & & 1,04 & 1,90 & & 1,06 & 0,64 & & 1,03 \\
\hline & $\begin{array}{r}\text { Bendras bibliotekos darbo } \\
\text { valandu skaičius per metus, } \\
\text { tenkantis } 1000 \text { gyventojų }\end{array}$ & 851,38 & & 1427,05 & 1723,48 & & 1094,42 & 1056,46 & & 1086,72 \\
\hline \multirow{5}{*}{ 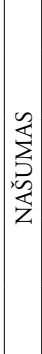 } & NAŠUMO İVERTINIMAS & & & & & & & & & \\
\hline & $\begin{array}{l}\text { Fondui komplektuoti skirtos } \\
\text { léšos, tenkančios } 1 \text { išduočiai }\end{array}$ & 0,36 & & 0,52 & 0,17 & & 0,56 & 0,64 & & 0,46 \\
\hline & $\begin{array}{r}\text { Darbuotojų darbo valandų ir } \\
\text { valandų, per kurias biblioteka } \\
\text { atvira lankytojams, santykis }\end{array}$ & 1,92 & & 1,42 & 1,54 & & 1,77 & 1,56 & & 1,64 \\
\hline & $\begin{array}{r}\text { Apsilankymų skaičius per } \\
1 \text { bibliotekos darbo valandą }\end{array}$ & 6,25 & & 3,22 & 4,53 & & 3,20 & 2,96 & & 3,99 \\
\hline & $\begin{array}{r}\text { Paprastosios } 1 \text { apsi- } \\
\text { lankymui skirtos išlaidos }\end{array}$ & 8,85 & & 11,02 & 5,76 & & 9,99 & 10,39 & & 9,37 \\
\hline \multirow{4}{*}{ 壳 } & PLĖTROS İVERTINIMAS & & & & & & & & & \\
\hline & Fondo atnaujinimo procentas & 4,07 & & 2,48 & 3,04 & & 2,20 & 2,97 & & 2,65 \\
\hline & $\begin{array}{r}1 \text { darbuotojo mokymams } \\
\text { skirtų valandų skaičius }\end{array}$ & 35,73 & & 16,02 & 22,41 & & 7,24 & 6,48 & & 36,98 \\
\hline & $\begin{array}{r}\text { Nepaprastosios išlaidos } \\
1 \text { gyventojui }\end{array}$ & 0,70 & & 0,83 & 4,66 & & 0,37 & 0,02 & & 38,08 \\
\hline
\end{tabular}


3 grupès bibliotekų I-IV dimensijų rodiklių skaitinės reikšmės (tęsinys)

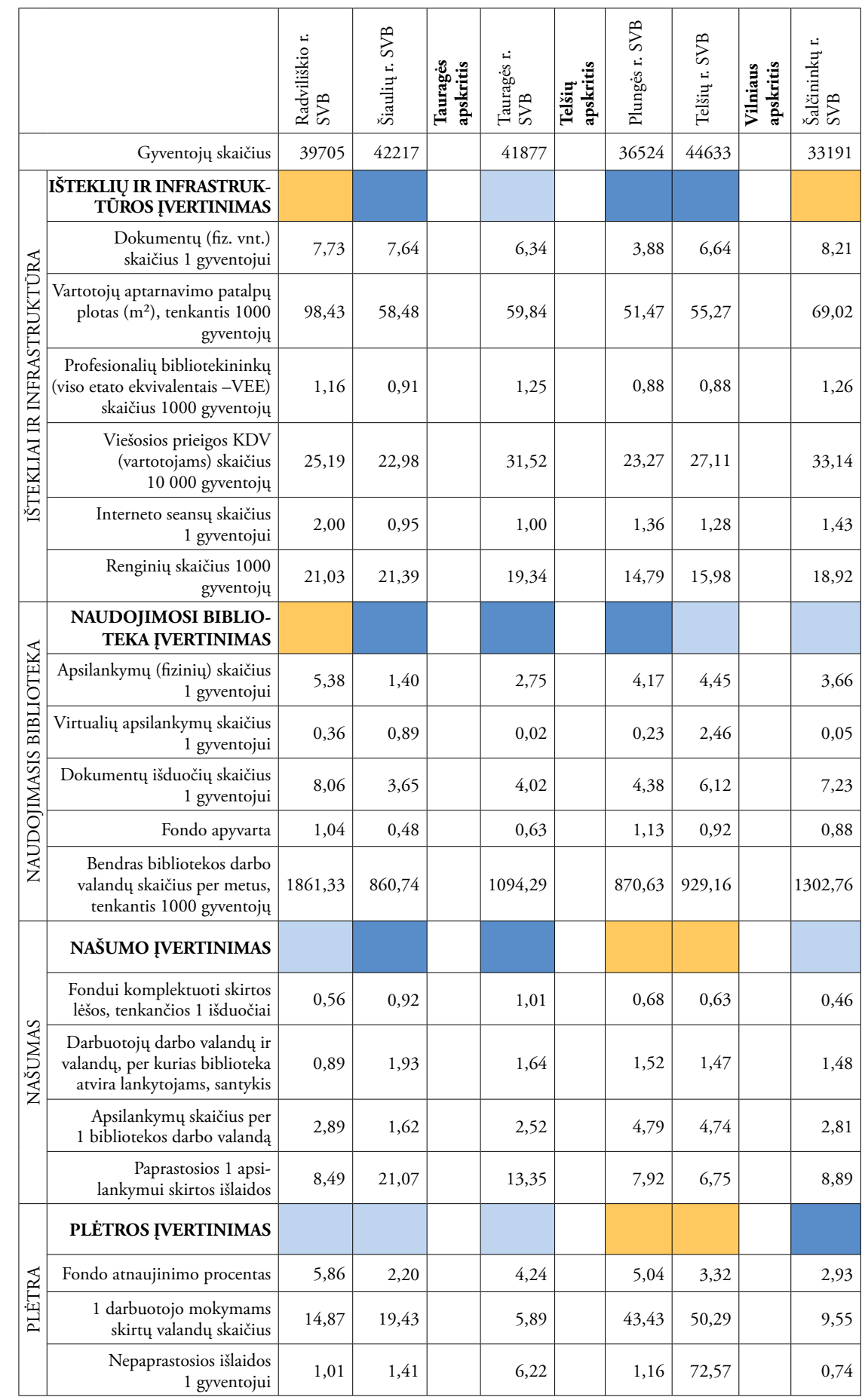


3 grupès bibliotekų I-IV dimensijų rodiklių skaitinės reikšmės (tęsinys)

\begin{tabular}{|c|c|c|c|c|c|}
\hline & 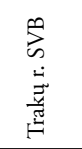 & 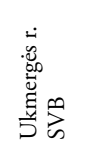 & 量 & 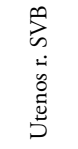 \\
\hline & Gyventojų skaičius & 33558 & 37561 & & 41018 \\
\hline \multirow{7}{*}{ 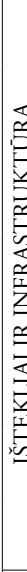 } & $\begin{array}{r}\text { IŠTEKLIÜ IR INFRASTRUK- } \\
\text { TÜROS ĮVERTINIMAS }\end{array}$ & & & & \\
\hline & $\begin{array}{r}\text { Dokumentų (fiz. vnt.) } \\
\text { skaičius } 1 \text { gyventojui }\end{array}$ & 6,92 & 5,80 & & 7,25 \\
\hline & $\begin{array}{r}\text { Vartotojų aptarnavimo patalpų } \\
\text { plotas }\left(\mathrm{m}^{2}\right) \text {, tenkantis } 1000 \\
\text { gyventojų }\end{array}$ & 48,51 & 82,37 & & 124,68 \\
\hline & $\begin{array}{r}\text { Profesionalių bibliotekininku } \\
\text { (viso etato ekvivalentais -VEE) } \\
\text { skaičius } 1000 \text { gyventojų }\end{array}$ & 1,04 & 1,21 & & 1,20 \\
\hline & $\begin{array}{r}\text { Viešosios prieigos KDV } \\
\text { (vartotojams) skaičius } \\
10000 \text { gyventojų }\end{array}$ & 21,75 & 25,29 & & 37,30 \\
\hline & $\begin{array}{r}\text { Interneto seansų skaičius } \\
1 \text { gyventojui }\end{array}$ & 1,48 & 1,47 & & 1,69 \\
\hline & $\begin{array}{r}\text { Renginių skaičius } 1000 \\
\text { gyventojų }\end{array}$ & 17,85 & 25,61 & & 12,90 \\
\hline \multirow{6}{*}{ 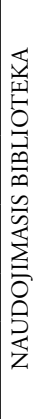 } & $\begin{array}{l}\text { NAUDOJIMOSI BIBLIO- } \\
\text { TEKA IৃVERTINIMAS }\end{array}$ & & & & \\
\hline & $\begin{array}{r}\text { Apsilankymų (fiziniu) skaičius } \\
1 \text { gyventojui }\end{array}$ & 4,21 & 4,68 & & 6,64 \\
\hline & $\begin{array}{r}\text { Virtualių apsilankymų skaičius } \\
1 \text { gyventojui }\end{array}$ & 0,26 & 2,11 & & 2,70 \\
\hline & $\begin{array}{r}\text { Dokumentų išduočiu skaičius } \\
1 \text { gyventojui }\end{array}$ & 8,61 & 7,05 & & 10,26 \\
\hline & Fondo apyvarta & 1,24 & 1,22 & & 1,42 \\
\hline & $\begin{array}{r}\text { Bendras bibliotekos darbo } \\
\text { valandų skaičius per metus, } \\
\text { tenkantis } 1000 \text { gyventojų }\end{array}$ & 842,21 & 1190,60 & & 935,39 \\
\hline \multirow{5}{*}{ 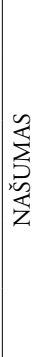 } & NAŠUMO İVERTINIMAS & & & & \\
\hline & $\begin{array}{l}\text { Fondui komplektuoti skirtos } \\
\text { léšos, tenkančios } 1 \text { išduočiai }\end{array}$ & 0,42 & 0,46 & & 0,51 \\
\hline & $\begin{array}{r}\text { Darbuotojų darbo valandu ir } \\
\text { valandu, per kurias biblioteka } \\
\text { atvira lankytojams, santykis }\end{array}$ & 1,82 & 1,61 & & 1,97 \\
\hline & $\begin{array}{r}\text { Apsilankymų skaičius per } \\
1 \text { bibliotekos darbo valandą }\end{array}$ & 5,00 & 3,93 & & 7,09 \\
\hline & $\begin{array}{r}\text { Paprastosios } 1 \text { apsi- } \\
\text { lankymui skirtos išlaidos }\end{array}$ & 9,03 & 9,48 & & 9,21 \\
\hline \multirow{4}{*}{ 壳 } & PLĖTROS İVERTINIMAS & & & & \\
\hline & Fondo atnaujinimo procentas & 3,74 & 3,28 & & 4,96 \\
\hline & $\begin{array}{l}1 \text { darbuotojo mokymams } \\
\text { skirtų valandų skaičius }\end{array}$ & 34,53 & 15,04 & & 29,42 \\
\hline & $\begin{array}{r}\text { Nepaprastosios išlaidos } \\
1 \text { gyventojui }\end{array}$ & 1,00 & 0,30 & & 3,17 \\
\hline
\end{tabular}




\section{4 grupès bibliotekų I-IV dimensijų rodiklių skaitinès reikšmès}

\begin{tabular}{|c|c|c|c|c|c|c|c|c|c|c|c|}
\hline & 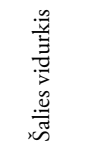 & 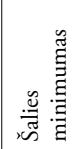 & 竘 & $\frac{n}{\frac{n}{2}}$ & 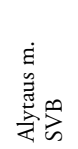 & 害营 & 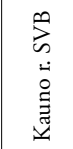 & 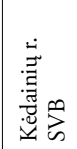 & 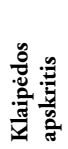 & 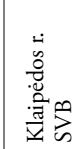 \\
\hline & Gyventojų skaičius & & & & & 56364 & & 87168 & 50906 & & 52140 \\
\hline \multirow{7}{*}{ 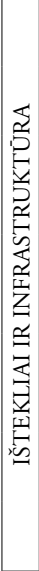 } & $\begin{array}{r}\text { IŠTEKILIU IR INFRASTRUK- } \\
\text { TÜROS İVERTINIMAS }\end{array}$ & & & & & & & & & & \\
\hline & $\begin{array}{r}\text { Dokumentų (fiz. vnt.) skaičius } \\
1 \text { gyventojui }\end{array}$ & 3,82 & 1,52 & 6,24 & & 2,67 & & 3,73 & 6,24 & & 5,05 \\
\hline & $\begin{array}{r}\text { Vartotojų aptarnavimo patalpu } \\
\text { plotas }\left(\mathrm{m}^{2}\right) \text {, tenkantis } 1000 \\
\text { gyventojų }\end{array}$ & 41,69 & 15,59 & 72,86 & & 26,44 & & 43,07 & 72,86 & & 44,65 \\
\hline & $\begin{array}{r}\text { Profesionalių bibliotekininkų } \\
\text { (viso etato ekvivalentais -VEE) } \\
\text { skaičius } 1000 \text { gyventojų }\end{array}$ & 0,66 & 0,43 & 0,98 & & 0,44 & & 0,52 & 0,98 & & 0,82 \\
\hline & $\begin{array}{r}\text { Viešosios prieigos KDV } \\
\text { (vartotojams) skaičius } \\
10000 \text { gyventojų } \\
\end{array}$ & 17,92 & 4,98 & 30,45 & & 8,16 & & 16,52 & 30,45 & & 25,89 \\
\hline & $\begin{array}{r}\text { Interneto seansų skaičius } \\
1 \text { gyventojui }\end{array}$ & 0,82 & 0,20 & 1,75 & & 0,20 & & 0,93 & 1,75 & & 0,81 \\
\hline & $\begin{array}{r}\text { Renginių skaičius } 1000 \\
\text { gyventojų }\end{array}$ & 11,87 & 2,41 & 25,52 & & 2,41 & & 21,88 & 25,52 & & 11,18 \\
\hline \multirow{6}{*}{ 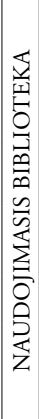 } & $\begin{array}{r}\text { NAUDOJIMOSI BIBLIO- } \\
\text { TEKA IৃERTINIMAS }\end{array}$ & & & & & & & & & & \\
\hline & $\begin{array}{r}\text { Apsilankymų (fizinių) skaičius } \\
1 \text { gyventojui } \\
\end{array}$ & 2,84 & 0,74 & 4,67 & & 2,47 & & 2,61 & 4,67 & & 3,87 \\
\hline & \begin{tabular}{|r|} 
Virtualių apsilankymu skaičius \\
1 gyventojui
\end{tabular} & 0,75 & 0,02 & 1,87 & & 0,16 & & 1,87 & 1,71 & & n.d. \\
\hline & $\begin{array}{r}\text { Dokumentų išduočiu skaičius } \\
1 \text { gyventojui }\end{array}$ & 4,73 & 1,64 & 8,86 & & 5,03 & & 3,59 & 8,86 & & 5,35 \\
\hline & Fondo apyvarta & 1,36 & 0,51 & 2,53 & & 1,89 & & 0,96 & 1,42 & & 1,06 \\
\hline & $\begin{array}{r}\text { Bendras bibliotekos darbo } \\
\text { valandu skaičius per metus, } \\
\text { tenkantis } 1000 \text { gyventojų }\end{array}$ & 635,56 & 146,81 & 1135,45 & & 146,81 & & 580,56 & 940,77 & & 1135,45 \\
\hline \multirow{5}{*}{ 离 } & NAŠUMO İVERTINIMAS & & & & & & & & & & \\
\hline & $\begin{array}{l}\text { Fondui komplektuoti skirtos } \\
\text { lëšos, tenkančios } 1 \text { išduočiai }\end{array}$ & 0,77 & 0,37 & 1,74 & & 0,58 & & 0,81 & 0,37 & & 0,60 \\
\hline & $\begin{array}{r}\text { Darbuotojų darbo valandų ir } \\
\text { valandu, per kurias biblioteka } \\
\text { atvira lankytojams, santykis }\end{array}$ & 2,16 & 1,04 & 4,27 & & 4,27 & & 1,46 & 2,11 & & 1,04 \\
\hline & $\begin{array}{r}\text { Apsilankymų skaičius per } \\
1 \text { bibliotekos darbo valandą }\end{array}$ & 6,40 & 1,03 & 16,81 & & 16,81 & & 4,49 & 4,96 & & 3,41 \\
\hline & $\begin{array}{r}\text { Paprastosios } 1 \text { apsi- } \\
\text { lankymui skirtos išlaidos }\end{array}$ & 10,84 & 7,12 & 28,56 & & 7,61 & & 10,05 & 7,12 & & 8,47 \\
\hline \multirow{4}{*}{ 変 } & PLĖTROS İVERTINIMAS & & & & & & & & & & \\
\hline & Fondo atnaujinimo procentas & 6,04 & 4,10 & 10,02 & & 5,13 & & 4,83 & 5,97 & & 4,27 \\
\hline & $\begin{array}{r}1 \text { darbuotojo mokymams } \\
\text { skirtų valandų skaičius }\end{array}$ & 24,70 & 11,50 & 42,22 & & 35,60 & & 42,22 & 15,09 & & 16,86 \\
\hline & $\begin{array}{r}\text { Nepaprastosios išlaidos } \\
1 \text { gyventojui }\end{array}$ & 1,19 & 0,00 & 6,94 & & 0,16 & & 0,64 & 0,75 & & 0,60 \\
\hline
\end{tabular}


4 grupès bibliotekų I-IV dimensijų rodiklių skaitinès reikšmès (tęsinys)

\begin{tabular}{|c|c|c|c|c|c|c|c|c|c|}
\hline \multirow{2}{*}{\multicolumn{2}{|c|}{ Gyventojų skaičius }} & 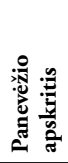 & 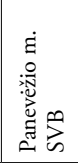 & 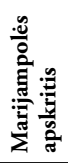 & 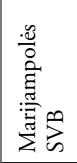 & 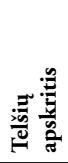 & 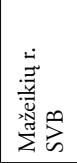 & 善高 & 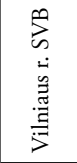 \\
\hline & & & 96345 & & 58714 & & 56143 & & 95052 \\
\hline \multirow{7}{*}{ 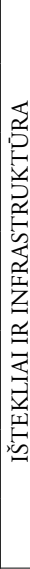 } & $\begin{array}{r}\text { IŠTEKLIÜ IR INFRASTRUK- } \\
\text { TÜROS ĮVERTINIMAS } \\
\end{array}$ & & & & & & & & \\
\hline & $\begin{array}{r}\text { Dokumentų (fiz. vnt.) skaičius } \\
1 \text { gyventojui }\end{array}$ & & 1,52 & & 3,41 & & 4,70 & & 3,24 \\
\hline & $\begin{array}{r}\text { Vartotojų aptarnavimo patalpų } \\
\text { plotas }\left(\mathrm{m}^{2}\right) \text {, tenkantis } 1000 \\
\text { gyventojų }\end{array}$ & & 15,59 & & 53,91 & & 47,59 & & 29,42 \\
\hline & $\begin{array}{r}\text { Profesionalių bibliotekininkų } \\
\text { (viso etato ekvivalentais -VEE) } \\
\text { skaičius } 1000 \text { gyventojų }\end{array}$ & & 0,43 & & 0,78 & & 0,74 & & 0,61 \\
\hline & $\begin{array}{r}\text { Viešosios prieigos KDV } \\
\text { (vartotojams) skaičius } \\
10000 \text { gyventojų } \\
\end{array}$ & & 4,98 & & 25,04 & & 17,28 & & 15,04 \\
\hline & $\begin{array}{r}\text { Interneto seansų skaičius } \\
1 \text { gyventojui }\end{array}$ & & 0,48 & & 0,75 & & 0,55 & & 1,07 \\
\hline & $\begin{array}{r}\text { Renginių skaičius } 1000 \\
\text { gyventojų }\end{array}$ & & 4,78 & & 10,95 & & 8,99 & & 9,25 \\
\hline \multirow{6}{*}{ 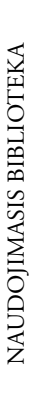 } & $\begin{array}{l}\text { NAUDOJIMOSI BIBLIO- } \\
\text { TEKA IৃVERTINIMAS }\end{array}$ & & & & & & & & \\
\hline & $\begin{array}{r}\text { Apsilankymų (fiziniu) skaičius } \\
1 \text { gyventojui }\end{array}$ & & 2,15 & & 3,62 & & 2,60 & & 0,74 \\
\hline & $\begin{array}{r}\text { Virtualių apsilankymų skaičius } \\
1 \text { gyventojui }\end{array}$ & & 0,88 & & 0,46 & & 0,14 & & 0,02 \\
\hline & $\begin{array}{r}\text { Dokumentų išduočiu skaičius } \\
1 \text { gyventojui }\end{array}$ & & 3,84 & & 5,05 & & 4,45 & & 1,64 \\
\hline & Fondo apyvarta & & 2,53 & & 1,48 & & 1,05 & & 0,51 \\
\hline & $\begin{array}{r}\text { Bendras bibliotekos darbo } \\
\text { valandų skaičius per metus, } \\
\text { tenkantis } 1000 \text { gyventojų }\end{array}$ & & 185,78 & & 632,64 & & 748,71 & & 713,75 \\
\hline \multirow{5}{*}{ 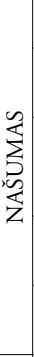 } & NAŠUMO İVERTINIMAS & & & & & & & & \\
\hline & $\begin{array}{l}\text { Fondui komplektuoti skirtos } \\
\text { lèšos, tenkančios } 1 \text { išduočiai }\end{array}$ & & 0,46 & & 0,78 & & 0,78 & & 1,74 \\
\hline & $\begin{array}{l}\text { Darbuotojų darbo valandų ir } \\
\text { valandu, per kurias biblioteka } \\
\text { atvira lankytojams, santykis }\end{array}$ & & 3,56 & & 1,98 & & 1,55 & & 1,31 \\
\hline & $\begin{array}{r}\text { Apsilankymų skaičius per } \\
1 \text { bibliotekos darbo valandą }\end{array}$ & & 11,57 & & 5,72 & & 3,22 & & 1,03 \\
\hline & $\begin{array}{r}\text { Paprastosios } 1 \text { apsi- } \\
\text { lankymui skirtos išlaidos }\end{array}$ & & 7,69 & & 8,50 & & 8,73 & & 28,56 \\
\hline \multirow{4}{*}{ 武 } & PLÉTROS İVERTINIMAS & & & & & & & & \\
\hline & Fondo atnaujinimo procentas & & 9,03 & & 10,02 & & 4,10 & & 4,96 \\
\hline & $\begin{array}{l}1 \text { darbuotojo mokymams } \\
\text { skirtų valandų skaičius }\end{array}$ & & 31,98 & & 17,38 & & 26,96 & & 11,50 \\
\hline & $\begin{array}{r}\text { Nepaprastosios išlaidos } \\
1 \text { gyventojui }\end{array}$ & & 0,18 & & 6,94 & & 0,00 & & 0,21 \\
\hline
\end{tabular}




\section{5 grupès bibliotekų I-IV dimensijų rodiklių reikšmès}

\begin{tabular}{|c|c|c|c|c|c|c|c|c|c|c|c|c|}
\hline & & 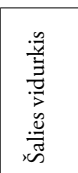 & 兽 & 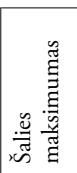 & 量 & 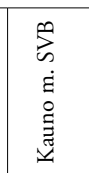 & 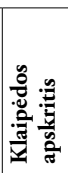 & 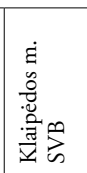 & 旁莺 & $\begin{array}{l}\sum_{\infty}^{\infty} \\
\dot{\Xi} \\
. \vec{\Xi} \\
\underset{\Xi}{\Xi}\end{array}$ & 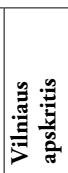 & 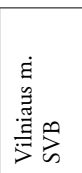 \\
\hline & Gyventojų skaičius & & & & & 304097 & & 157350 & & 105653 & & 539939 \\
\hline & $\begin{array}{r}\text { IŚTEKLIUU IR INFRASTRUK- } \\
\text { TÜROS İVERTINIMAS }\end{array}$ & & & & & & & & & & & \\
\hline$\$$ & $\begin{array}{r}\text { Dokumentu (fiz. vnt.) skaičius } \\
1 \text { gyventojui }\end{array}$ & 1,79 & 1,00 & 2,17 & & 1,93 & & 2,17 & & 2,06 & & 1,00 \\
\hline 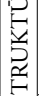 & $\begin{array}{r}\text { Vartotojų aptarnavimo patalpų } \\
\text { plotas }\left(\mathrm{m}^{2}\right) \text {, tenkantis } 1000 \\
\text { gyventojų }\end{array}$ & 15,80 & 5,96 & 22,88 & & 14,58 & & 22,88 & & 19,78 & & 5,96 \\
\hline 胥 & $\begin{array}{r}\text { Profesionaliu bibliotekininkų } \\
\text { (viso etato ekvivalentais -VEE) } \\
\text { skaičius } 1000 \text { gyventojų }\end{array}$ & 0,34 & 0,21 & 0,40 & & 0,38 & & 0,36 & & 0,40 & & 0,21 \\
\hline 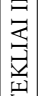 & $\begin{array}{r}\text { Viešosios prieigos KDV } \\
\text { (vartotojams) skaičius } \\
10000 \text { gyventojų }\end{array}$ & 5,22 & 2,39 & 7,37 & & 4,11 & & 7,37 & & 7,00 & & 2,39 \\
\hline 悉 & $\begin{array}{r}\text { Interneto seansų skaičius } \\
1 \text { gyventojui }\end{array}$ & 0,39 & 0,23 & 0,54 & & 0,40 & & 0,40 & & 0,54 & & 0,23 \\
\hline & $\begin{array}{r}\text { Renginių skaičius } 1000 \\
\text { gyventojų }\end{array}$ & 3,01 & 2,14 & 4,07 & & 2,75 & & 3,08 & & 4,07 & & 2,14 \\
\hline$\varangle$ & $\begin{array}{l}\text { NAUDOJIMOSI BIBLIO- } \\
\text { TEKA IৃVERTINIMAS }\end{array}$ & & & & & & & & & & & \\
\hline 竧 & $\begin{array}{r}\text { Apsilankymų (fiziniu) skaičius } \\
1 \text { gyventojui }\end{array}$ & 1,90 & 1,50 & 2,50 & & 1,82 & & 2,50 & & 1,79 & & 1,50 \\
\hline$\stackrel{\bullet}{a}$ & $\begin{array}{r}\text { Virtualių apsilankymų skaičius } \\
1 \text { gyventojui }\end{array}$ & 0,57 & 0,07 & 1,81 & & 0,15 & & 1,81 & & 0,23 & & 0,07 \\
\hline 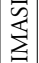 & $\begin{array}{r}\text { Dokumentų išduočiu skaičius } \\
1 \text { gyventojui }\end{array}$ & 3,40 & 2,54 & 4,39 & & 3,32 & & 4,39 & & 3,36 & & 2,54 \\
\hline O) & Fondo apyvarta & 1,98 & 1,63 & 2,55 & & 1,72 & & 2,02 & & 1,63 & & 2,55 \\
\hline 胥 & $\begin{array}{r}\text { Bendras bibliotekos darbo } \\
\text { valandu skaičius per metus, } \\
\text { tenkantis } 1000 \text { gyventojų }\end{array}$ & 166,75 & 87,22 & 211,97 & & 211,97 & & 209,58 & & 158,23 & & 87,22 \\
\hline & NAŠUMO İVERTINIMAS & & & & & & & & & & & \\
\hline & $\begin{array}{l}\text { Fondui komplektuoti skirtos } \\
\text { léšos, tenkančios } 1 \text { išduočiai }\end{array}$ & 0,40 & 0,37 & 0,43 & & 0,37 & & 0,43 & & 0,38 & & 0,41 \\
\hline 离 & $\begin{array}{l}\text { Darbuotojų darbo valandų ir } \\
\text { valandu, per kurias biblioteka } \\
\text { atvira lankytojams, santykis }\end{array}$ & 3,15 & 2,23 & 3,84 & & 2,76 & & 2,23 & & 3,84 & & 3,78 \\
\hline & $\begin{array}{l}\text { Apsilankymų skaičius per } \\
1 \text { bibliotekos darbo valandą }\end{array}$ & 12,25 & 8,57 & 17,20 & & 8,57 & & 11,93 & & 11,30 & & 17,20 \\
\hline & $\begin{array}{r}\text { Paprastosios } 1 \text { apsi- } \\
\text { lankymui skirtos išlaidos }\end{array}$ & 6,38 & 5,31 & 7,49 & & 7,49 & & 5,31 & & 7,22 & & 5,49 \\
\hline & PLĖTROS İVERTINIMAS & & & & & & & & & & & \\
\hline 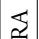 & Fondo atnaujinimo procentas & 5,73 & 3,23 & 8,18 & & 6,01 & & 5,48 & & 3,23 & & 8,18 \\
\hline 经 & $\begin{array}{l}1 \text { darbuotojo mokymams } \\
\text { skirtų valandų skaičius }\end{array}$ & 13,44 & 3,54 & 22,82 & & 22,82 & & 6,49 & & 20,89 & & 3,54 \\
\hline & $\begin{array}{r}\text { Nepaprastosios išlaidos } \\
1 \text { gyventojui }\end{array}$ & 0,54 & 0,09 & 1,45 & & 0,15 & & 0,47 & & 0,09 & & 1,45 \\
\hline
\end{tabular}

